
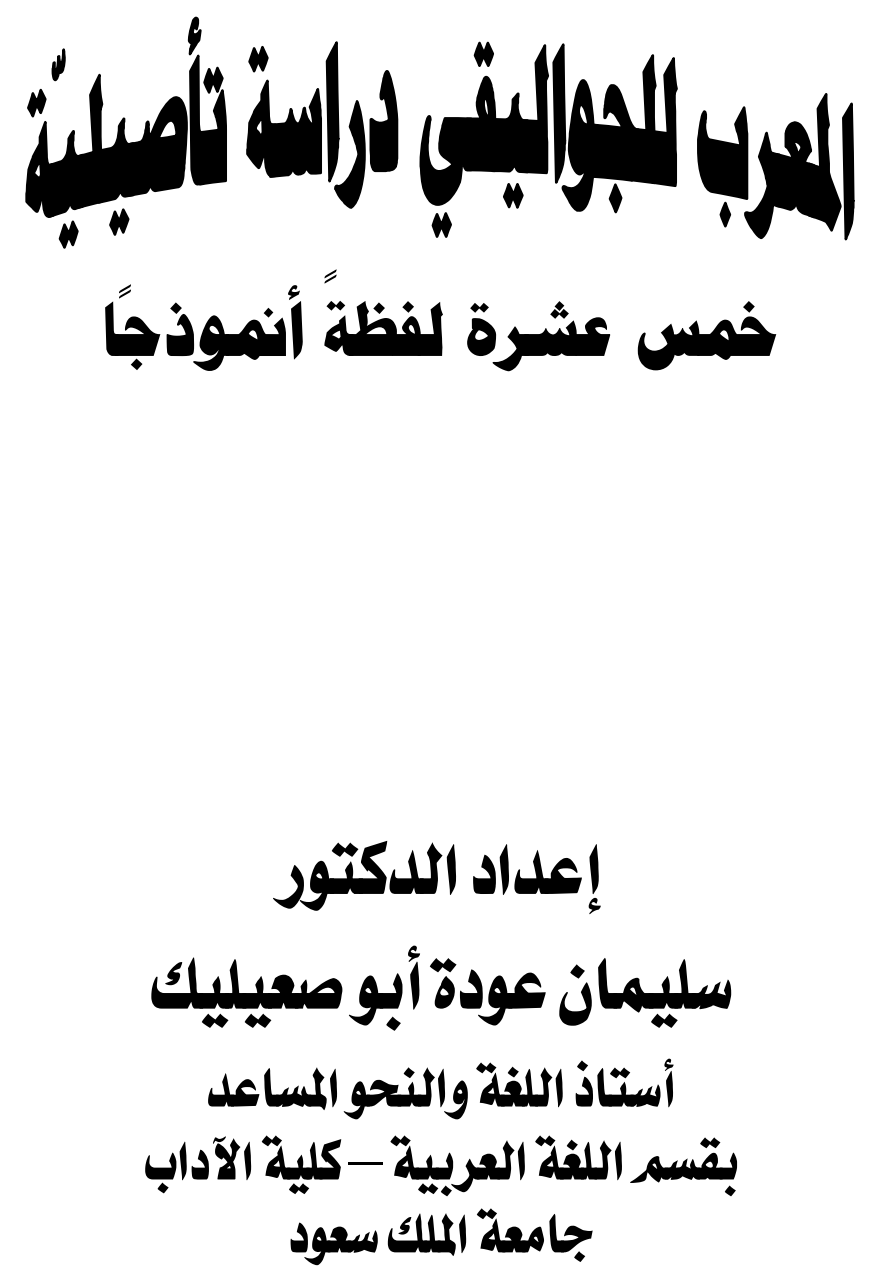


\section{هذم البحث:}

يدرس هذا البحث المُعَرَب للجواليقيّ دراسة تأصيليّة، خمس عشرة لفظةً

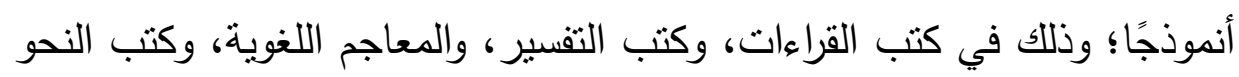
والصرف، وكتب اللغات، وغيرها من الكتب المختلفة. ويتتاول هذا البحث خمس عشرة لفظةً من ألفاظ القرآن الكريم، ذكرها

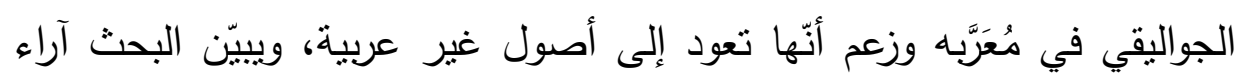

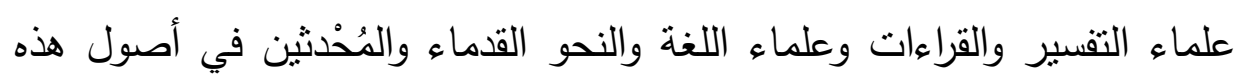
الألفاظ. ومدى موافقتها لما ذكره الجواليقيّ ومن نقل عنهم.

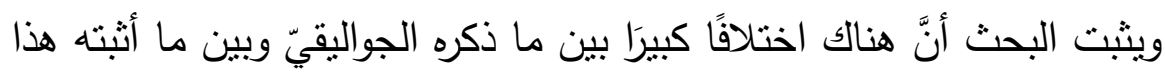

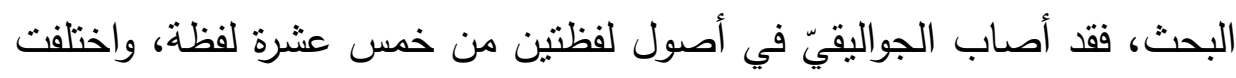

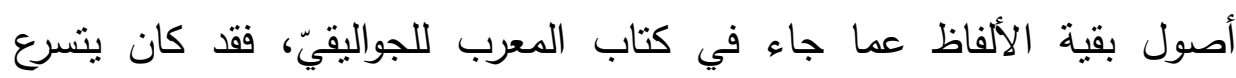

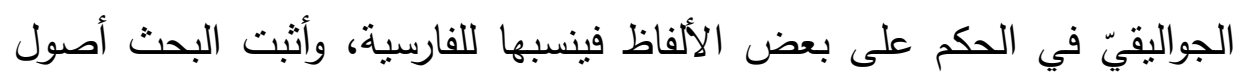
كلّ لفظة، وردها إلى اللغة التي هي منها.

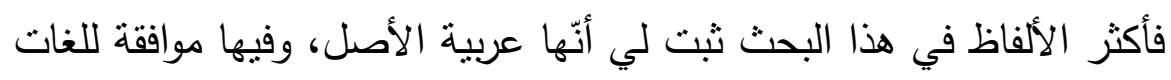

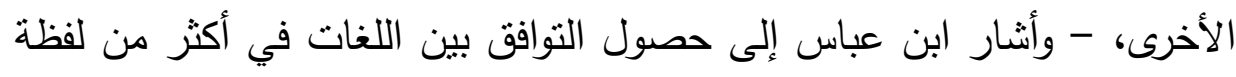

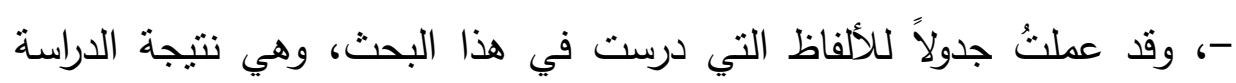
التأصيليّة، وهو في آخر البحث. كلمات مفتاحية: المُعرَّب، الجواليقيّ، دراسة تأصيليّة، ألفاظ القرآن الكريم. 


\section{المقدمة:}

الحمد لله ربّ العالمين والصلاة والسلام على سيدنا محمٍٍ وعلى آله وصحبه

$$
\text { أجمعين، أما بعد: }
$$

فهذا البحث يقوم باختيار خمس عشرة لفظة من " كتاب المُعرَّب " للجواليقيّ

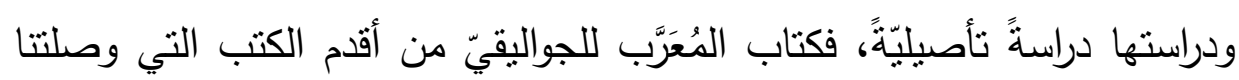
في موضوع المُعرَّب في كلام العرب، وقد نتَّ اختيار هذه الألفاظ اختيارًا عشوائيا

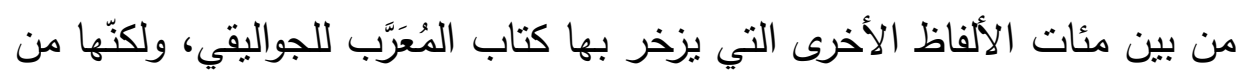
ألفاظ القرآن الكريم.

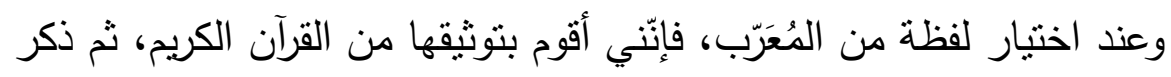

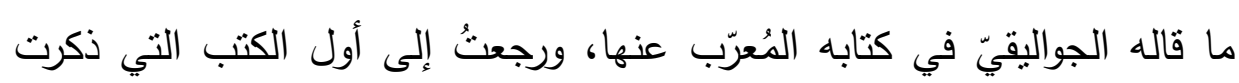

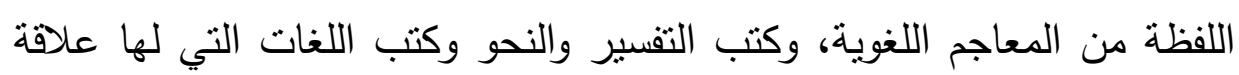

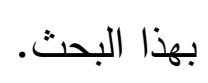

وقد حاولتُ البحث عن أصول هذه الألفاظ في لغتتا العربية، ثم مقارنة ما هو

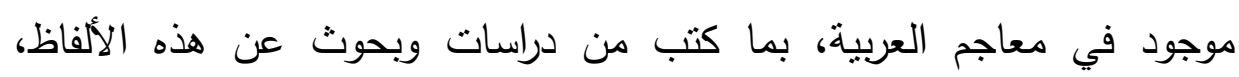
والترجيح بين أصل هذه الألفاظ.

وقد أثبت البحث أنَّ أكثر هذه الألفاظ عربية الأصل، وليست معربة كما ذكر الجواليقيّ، أو من نقل عنهم في كتابه.

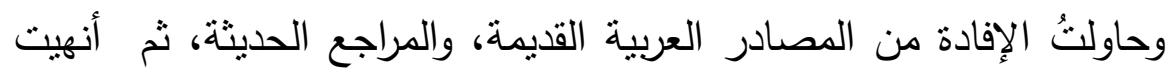
البحث بخاتمة تضمنت أهم النتائج التي توصلت إليها.

$$
\text { وآخر دعوانا أنِ الحمد للّه رب العالمين }
$$

$\overline{=}$ 


\section{تمهيد: المُعَرَّب: -}

عرَّف الجرجاني المُعَرََّب بقوله ('):" المُعَرَب: اسم مفعول من التعربب، وهو عندََ أهل العربية لفظ وضعه غير العرب لمعنى استعمله العرب". وقد اختلف العلماء في وقوع المُعَرَب في القرآن الكريم، وانقسموا إلى ثلاث

الأولى: ترى عدم وقوع المُعََّب في القرآن الكريم، وممن قال به الإمام الثافعي، وأبو عبيدة، والطبري، والقاضي أبو بكر بن الطبب، وابن فارس،

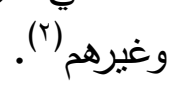

والثانية: ترى أن المُعَرَب موجود في القرآن الكريم، وممن قال به ابن دريد،

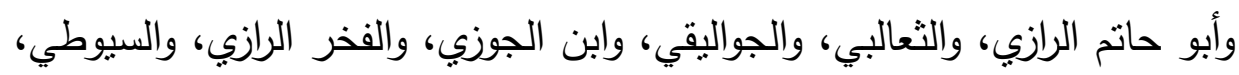

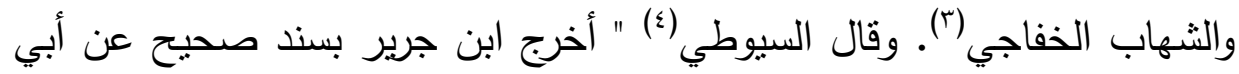

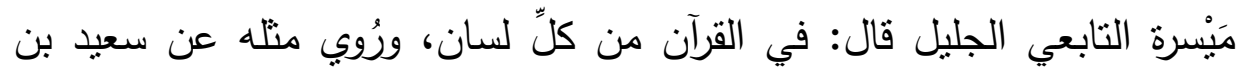

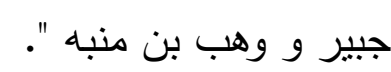
والثالثة: حاولت أن توفق بين الفرقتين السابقتين، ومن هذه الفرقة أبو عبيد

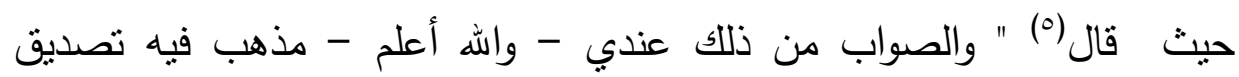

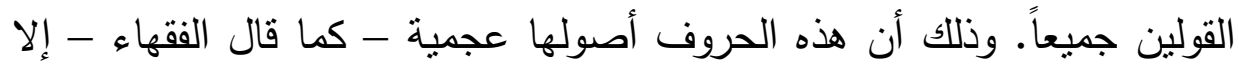
أنها سقطت إلى العرب، فأعربتها بألسنتها، وحولتها عن ألفاظ العجم إلى ألفاظها فصارت عربيّة. ثم نزل القرآن، وقد اختلطت هذه الحروف بكلام العرب. فمن قال إنَّها عربية فهو صادق، ومن قال عجمية فهو صادق تمرن ".

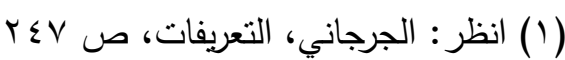

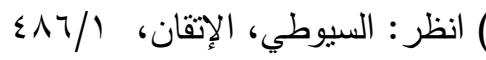

(r) انظر : بسمة الرواشدة، القضايا اللغوية في كتاب " الصاحة الصاحبي في فقه اللغة " لابن فارس،

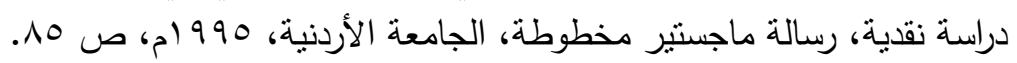

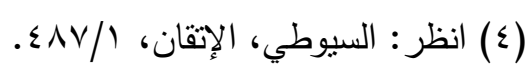

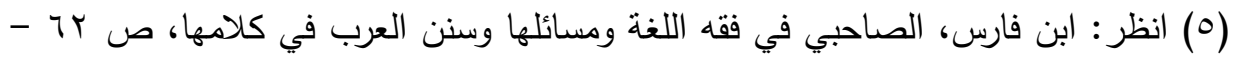

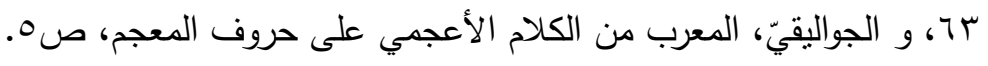




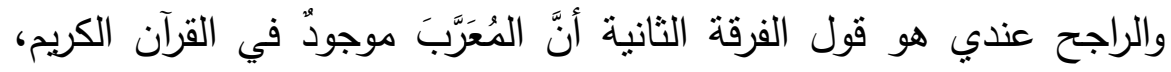

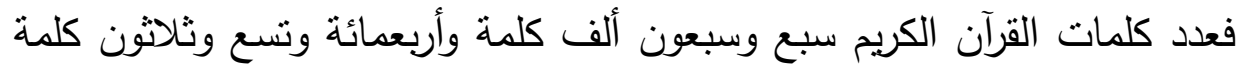

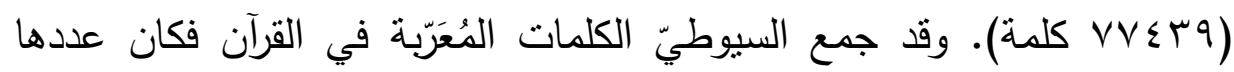

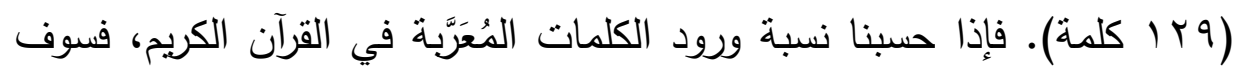

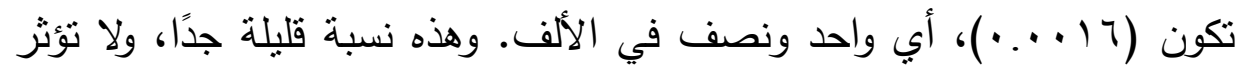

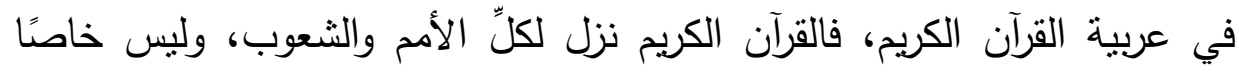
بالعرب وحدهم، وإنْ كان بلغتهم.

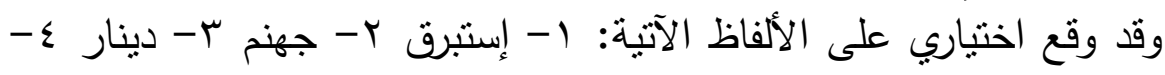

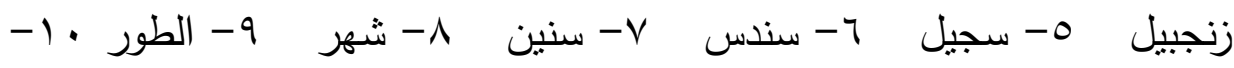

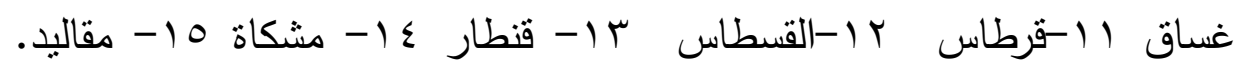
وسأدرسها بالتقصيل كما هو آتٍ:

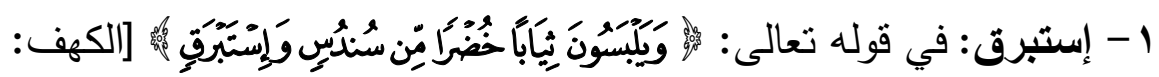

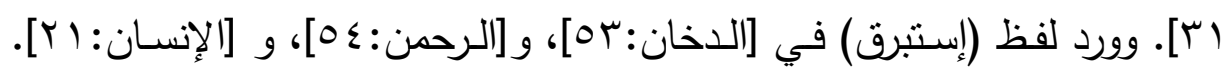

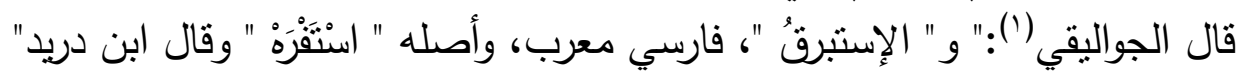

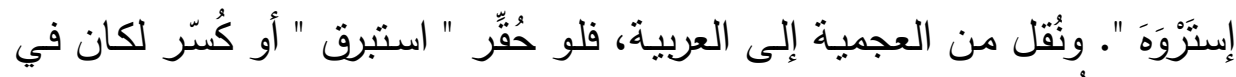

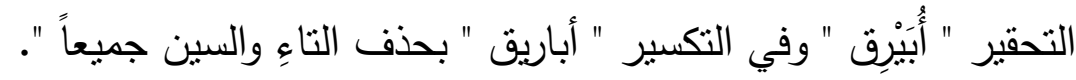

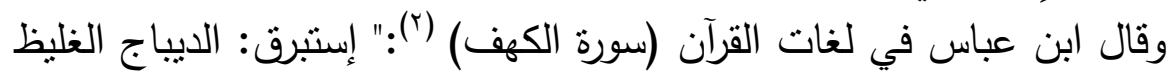

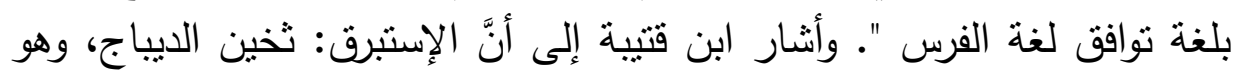

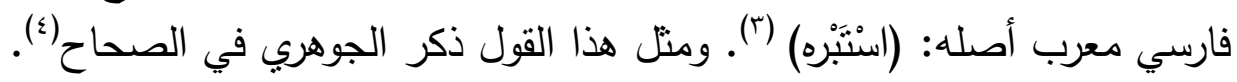

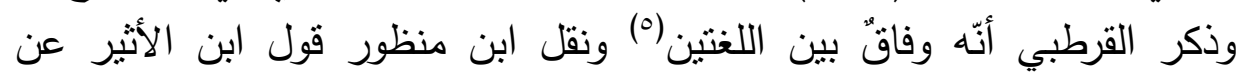

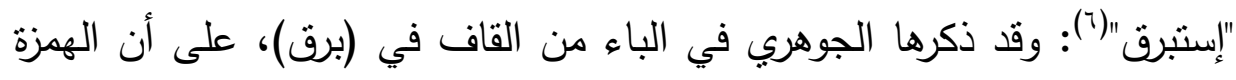

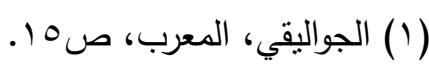

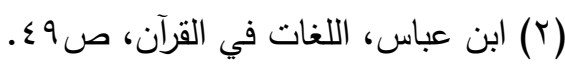

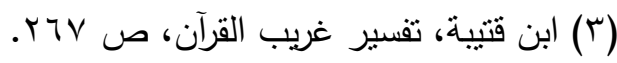

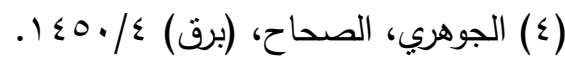

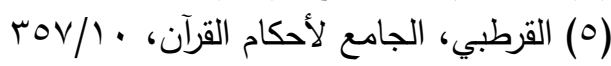

$$
\begin{aligned}
& \text { (T) ابن منظور ، لسان العرب، (إستبرق) . }
\end{aligned}
$$




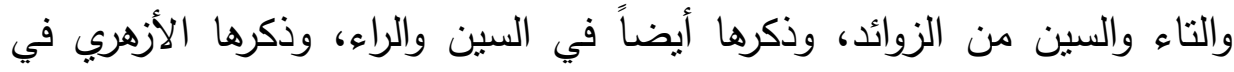

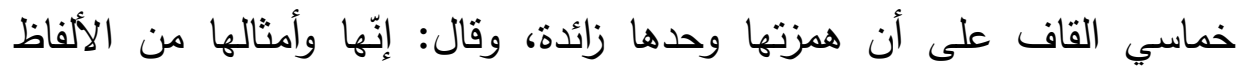

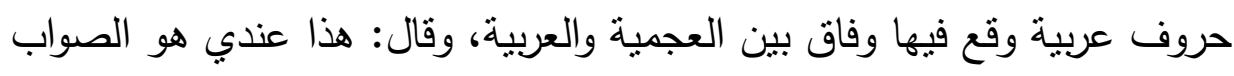

وقال ابن منظور ('):" والبُرقة والبَرقاء غلظ فيه حجارة ورمل ... الأصمعي:

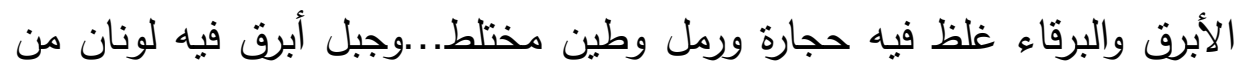
سواد وبياض، ويقال

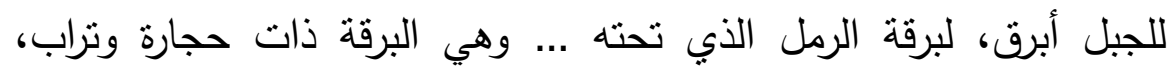

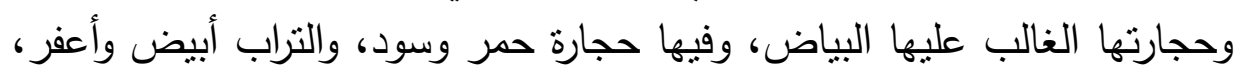

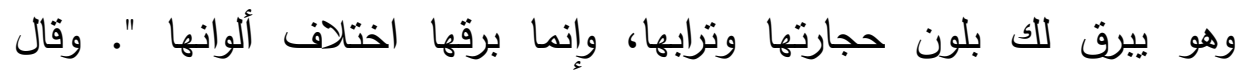

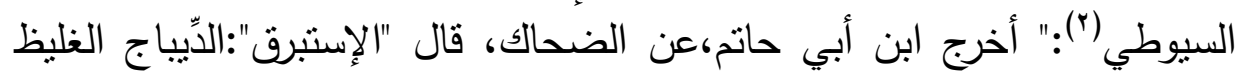

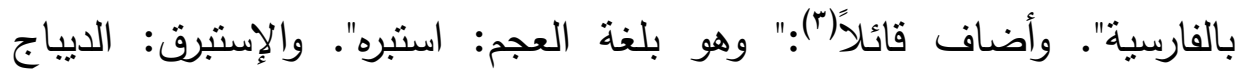

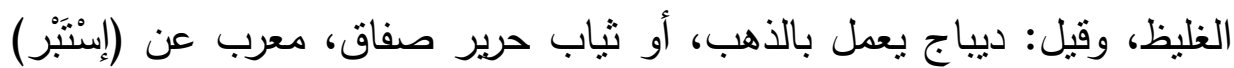

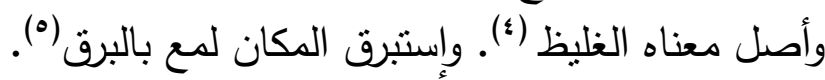

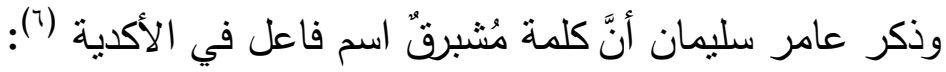

\begin{tabular}{|c|c|c|c|}
\hline 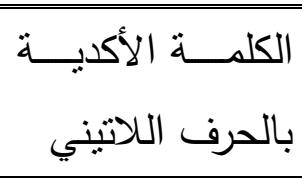 & المعنى & الجذر & |الكلمة الأكدية \\
\hline musabripu & 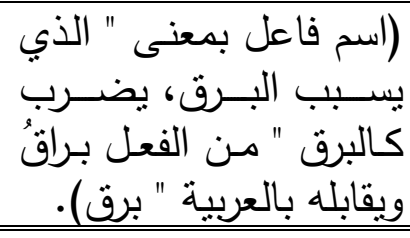 & برق & مُشَبَبْرَقُ \\
\hline & 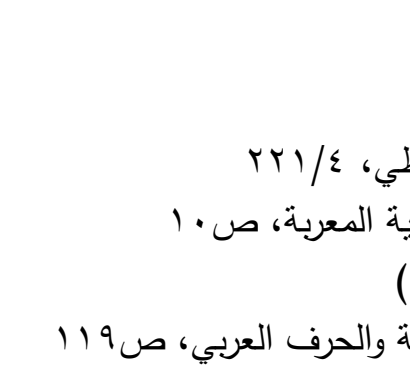 & 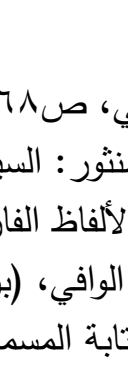 & 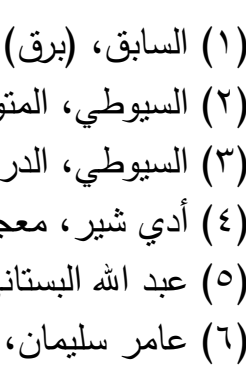 \\
\hline
\end{tabular}




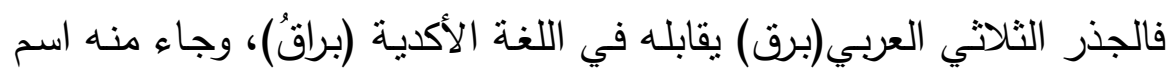

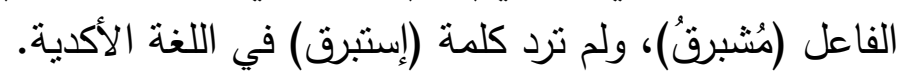

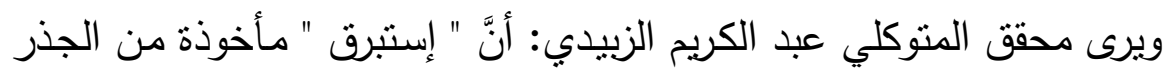

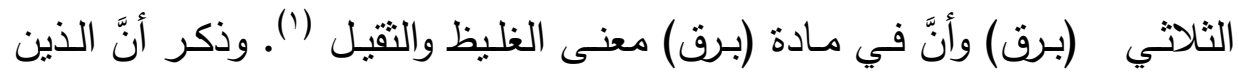

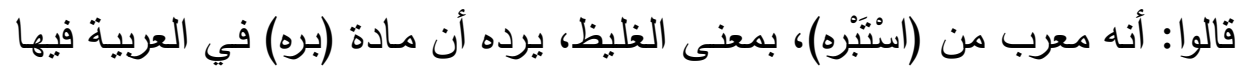
معنى الغليظ والثديد، كما نقل

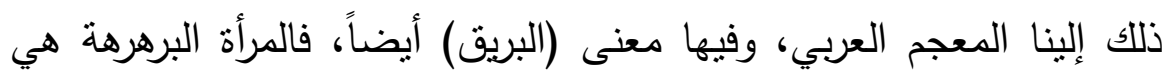

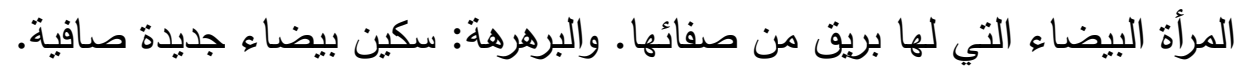

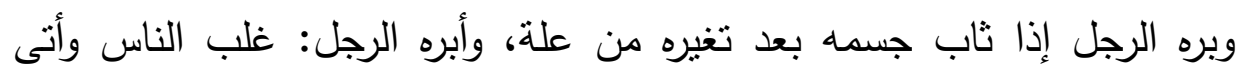

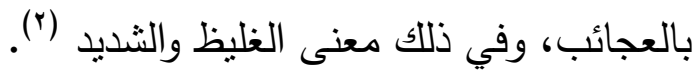

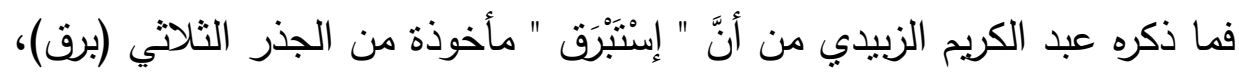

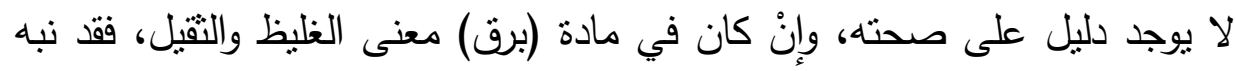

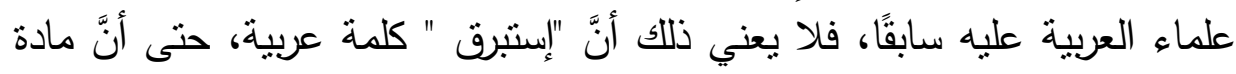

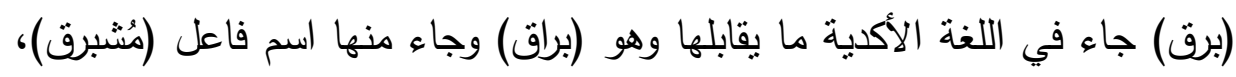

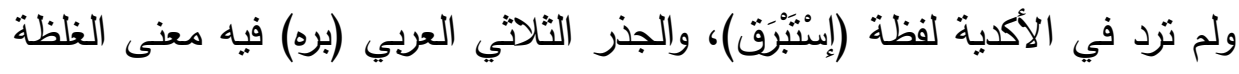
وغيره من المعاني، ولكنّه في العربية ليس أصل (اسْتَبْره).

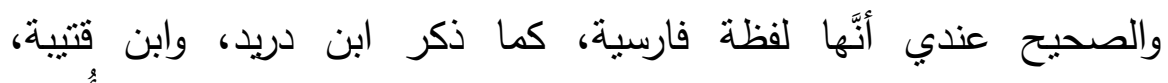

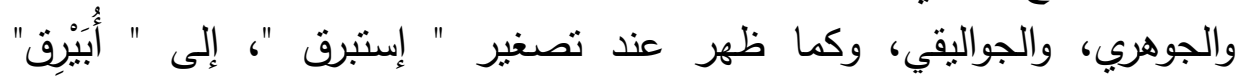

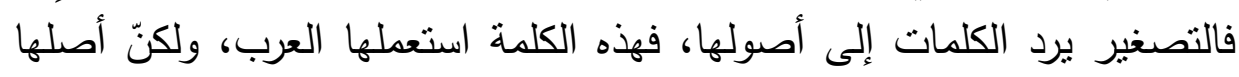

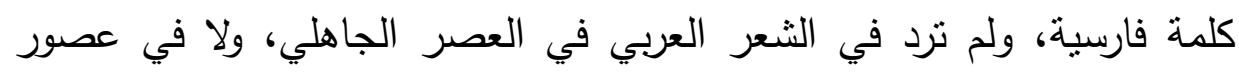

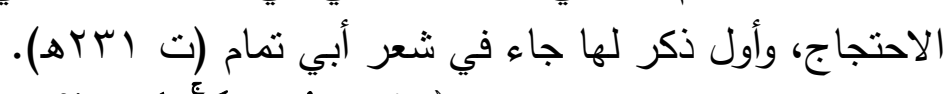

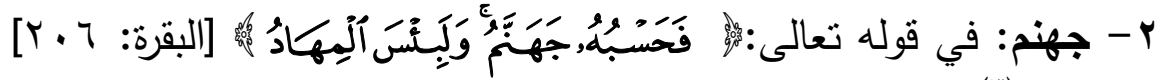

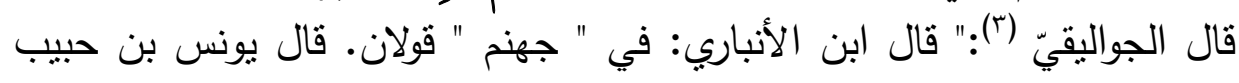

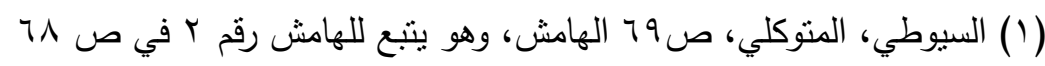

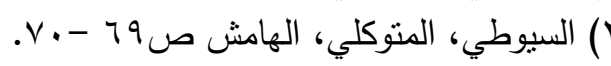

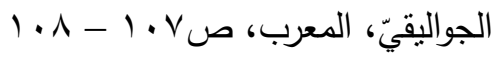




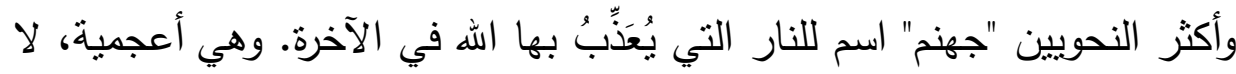

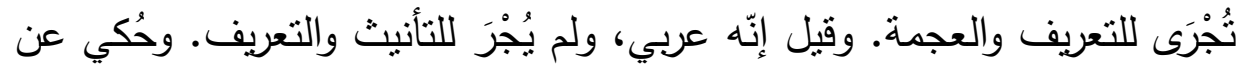

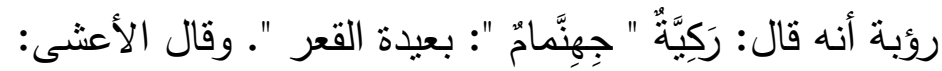

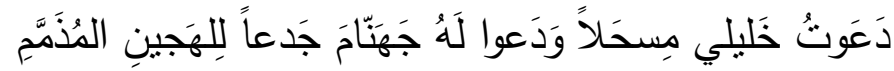

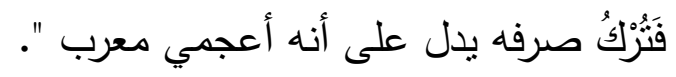

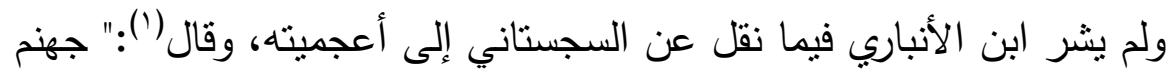

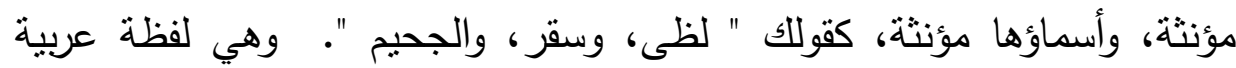

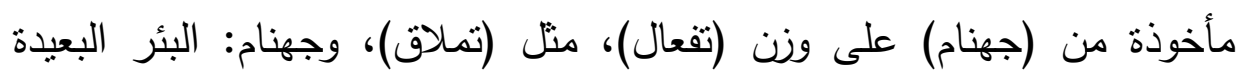

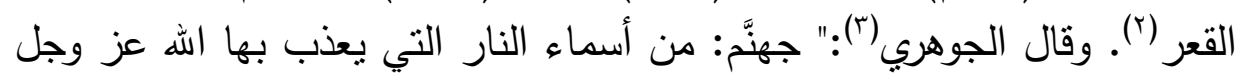

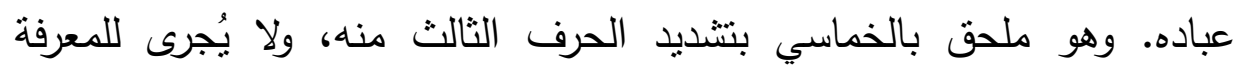

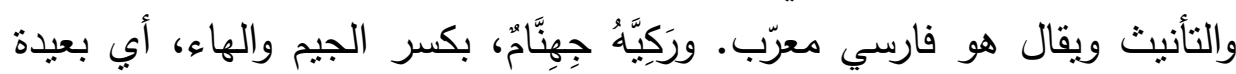

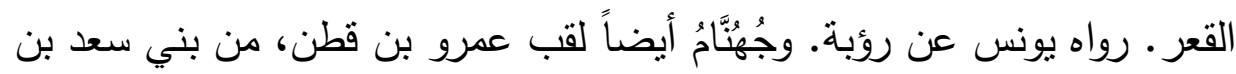

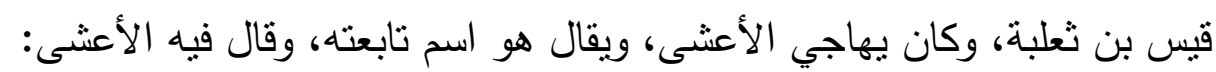

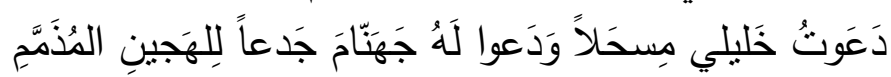

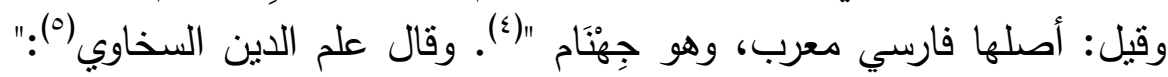

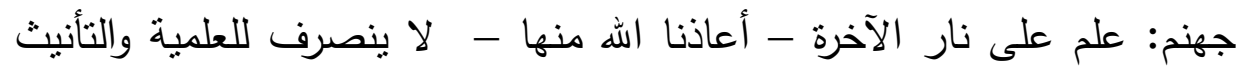

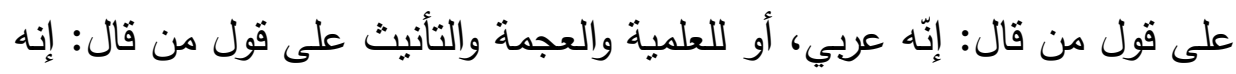

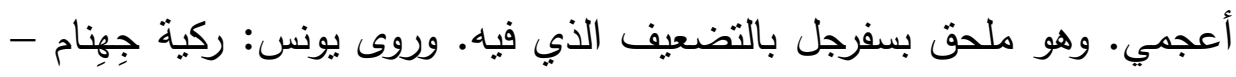

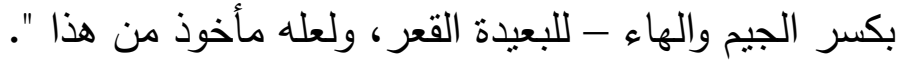

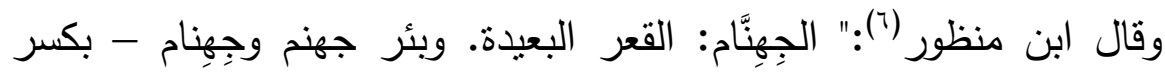
الجيم والهاء- بعيدة القعر ، وبه سميث جهنم لبعد قعرها. وقال اللحياني: جهنام وجنام

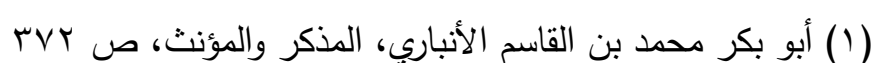

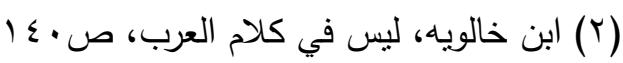

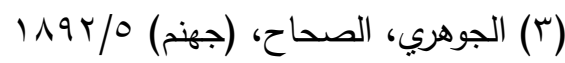

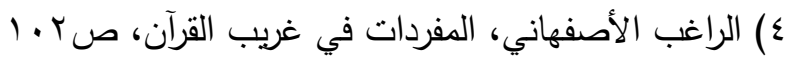

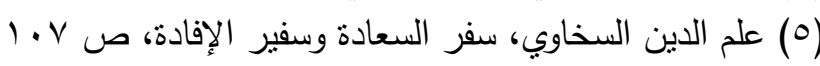

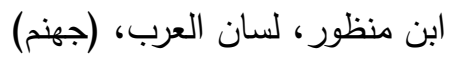




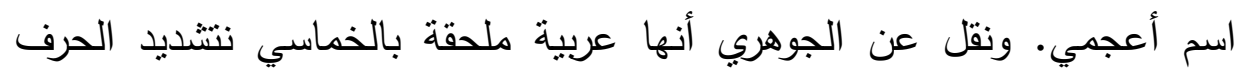

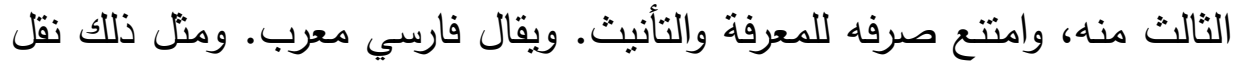
عن الأزهري ".

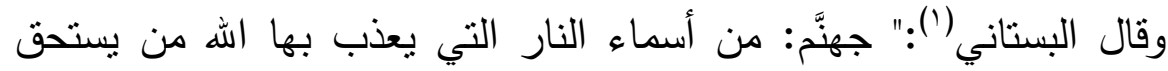
العذاب من عبيده،وفيها قولان قال يونس لا تُصرف للتعريف والعجمة والتأنيث التيث أيضاً، وقال آخرون جهنَّم عربي سميت نار فار الآخرة بها لبعد قعرها وإنما لم تُجْرَ لتقل التعريف وتقل التأنيث ".

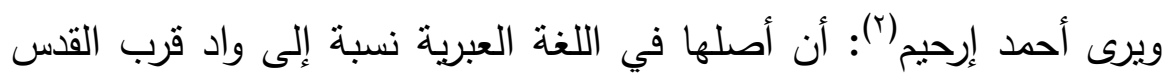

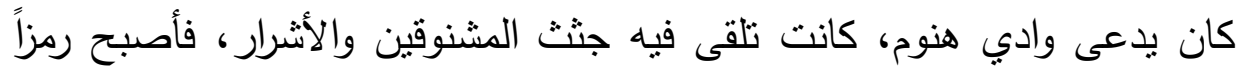

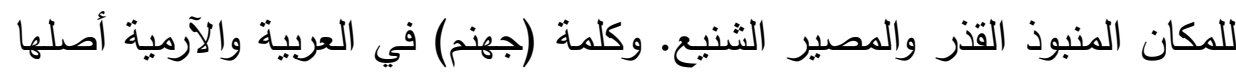

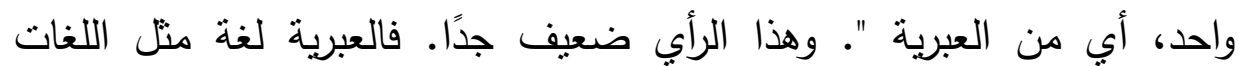

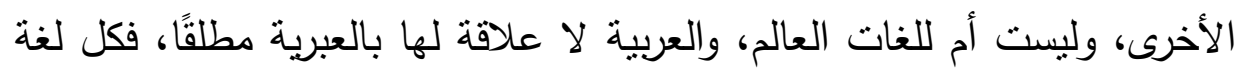
من شجرة تختلف عن اللغة الأخرى. وفي الحقيقة إنَّ أئمة اللغة ذكروا فيها قولين: الإنها: أحدهما القول بأنها عربية

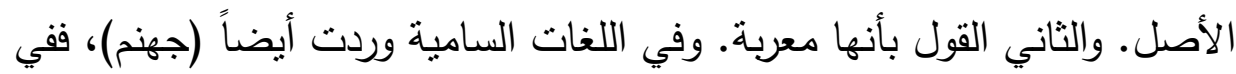
السريانية (جيهنوم) و (جيهنا) أي جهنم. ونقل ابن منظول الأنور أنها بالعبرية (كهنام).

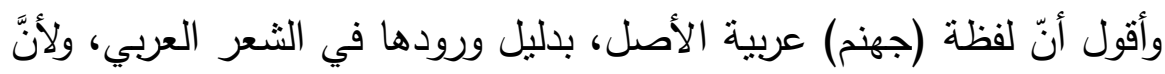
اشتقاقها يدل على عربيتها، وورودها في القرآن الكريم سبع وسبعون (VV) مرة. ويظهر أنّها وافقت اللغات الأخرى متل الآرامية والسريانية والعبرية والفارسية.

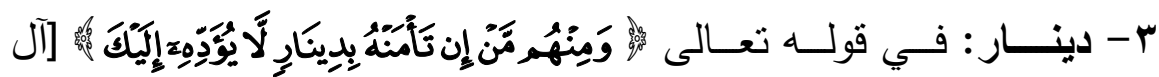

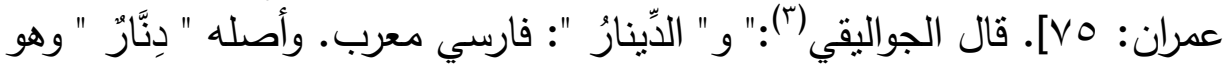

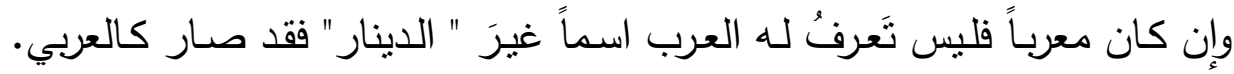

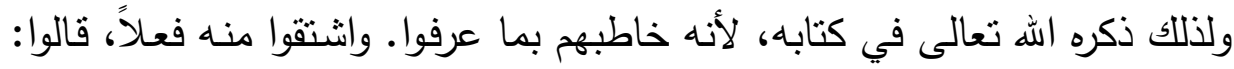

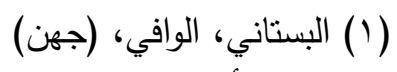

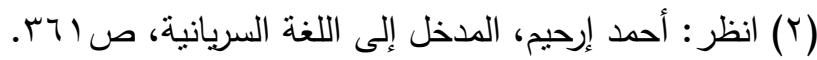

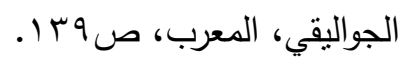




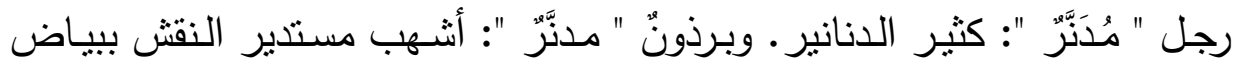
وسواد.

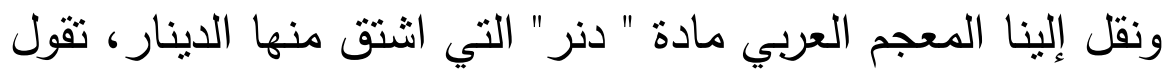

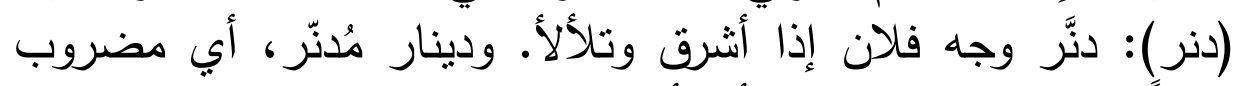

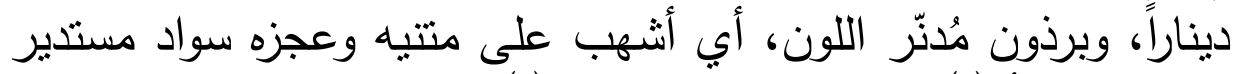

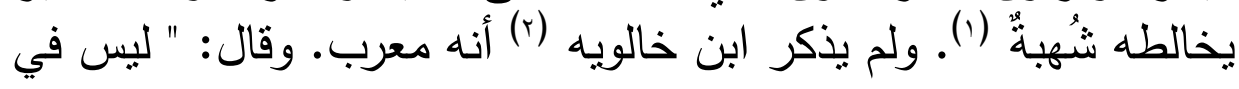

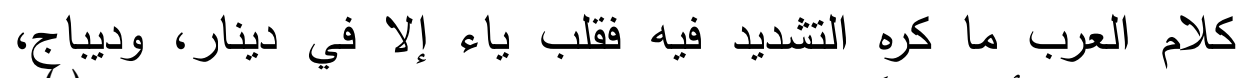

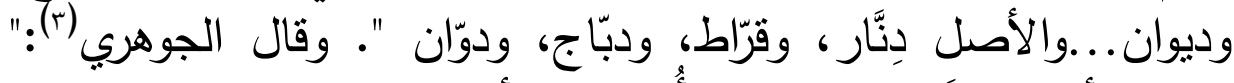

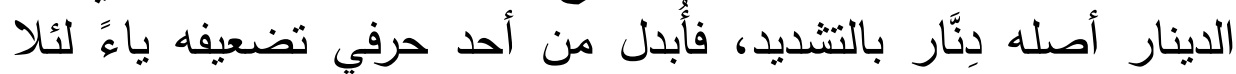

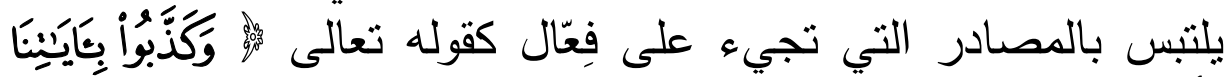

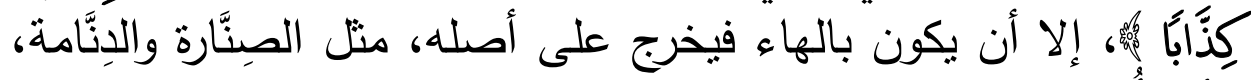

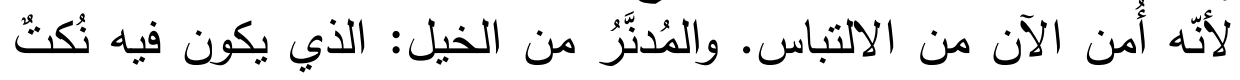

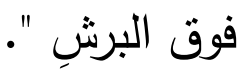

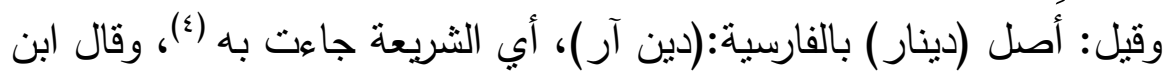

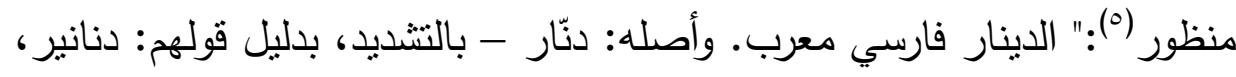

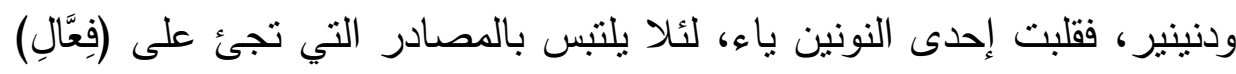

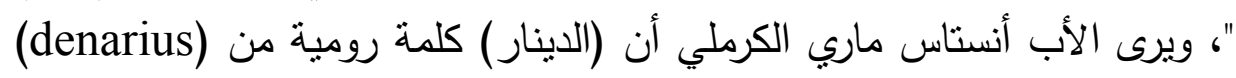

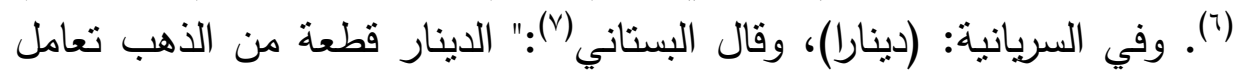

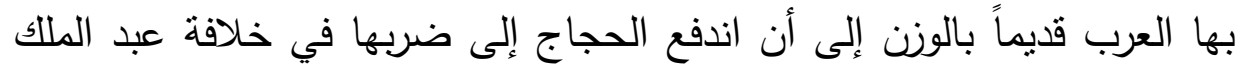

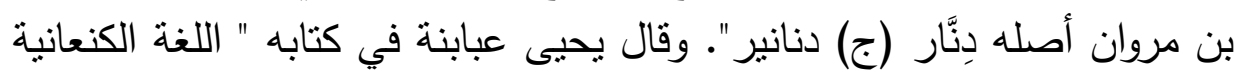

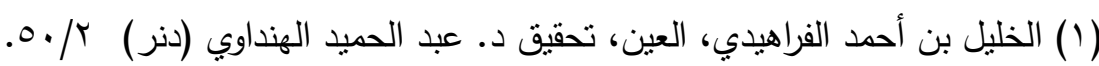

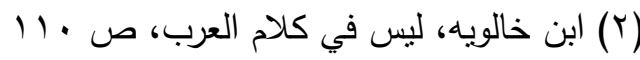

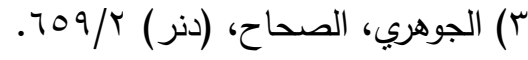

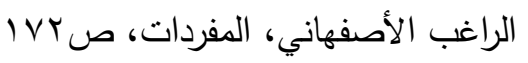

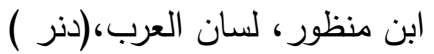

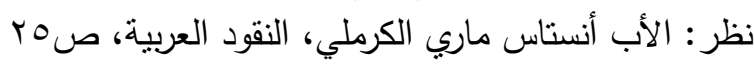

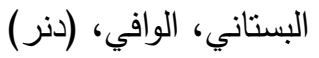




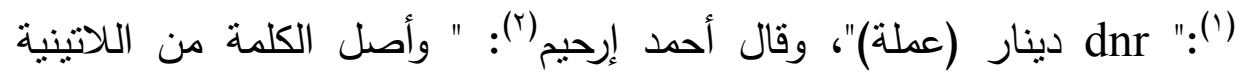
(ديناريوس) (" (1)

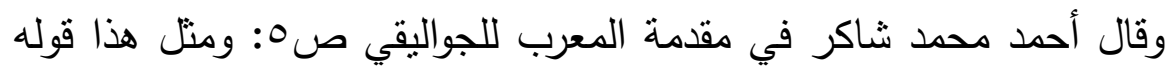

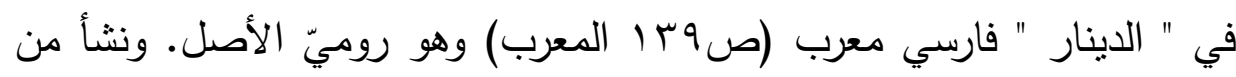

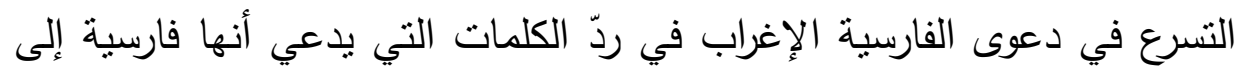
أصول في لغة الفرس.

فما ذكره الجواليقيّ بأنَّ (الدينار) فارسي معرب، وقد تابعه في ذلك الراغب

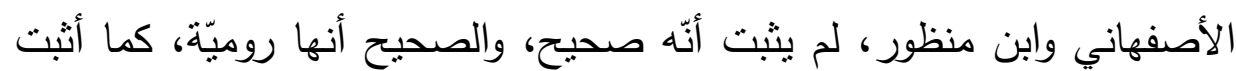

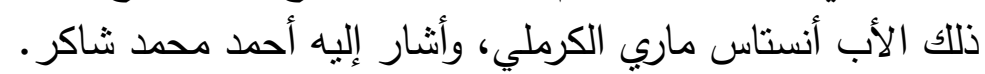

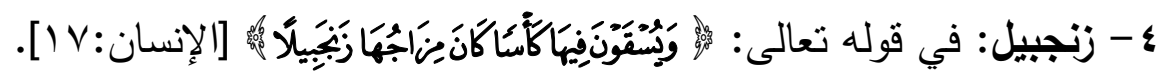

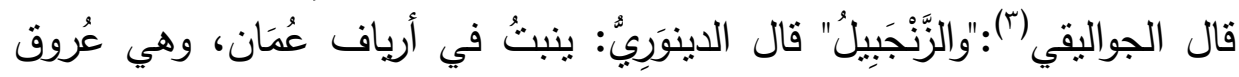

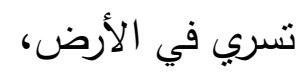
وليس بشجر ، ونباته منل الراسن، وهو يؤكل رطباً. قال: وأجود ما يحمل من الرن

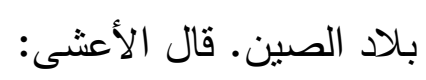

كأن القرنفل والزنجبـ بيل باتا بفيها وأرياً مَشُورا.

ويرى الفراء أنّ العرب تصف الزنجبيل بالطيب وهو مستطاب عندهم جداً

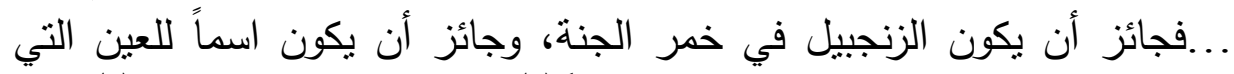

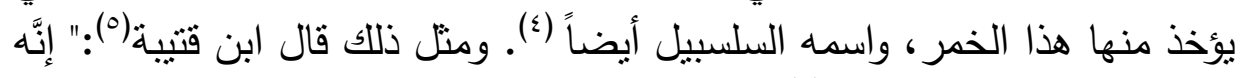

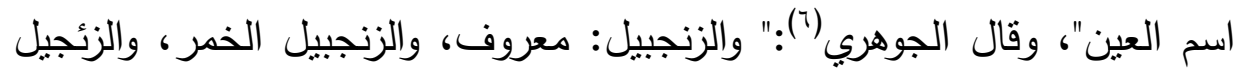

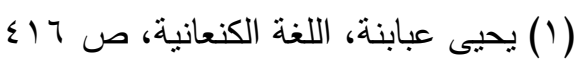

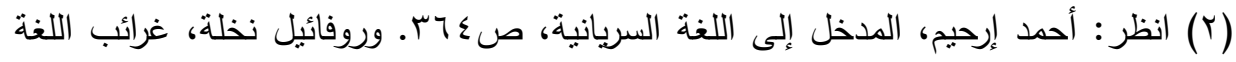

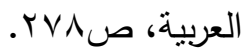

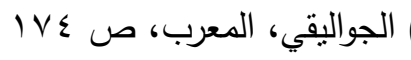

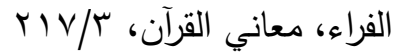

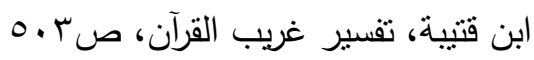

$$
\begin{aligned}
& \text { الجوهري، الصحاح، (زجل) \& / }
\end{aligned}
$$


بالهمز : الرجل الضعيف البدن، عن الفراء، ويقال الزنجيل بالنون، قال أبو عبيد: الذي قاله الفراء هو الدحفوظ عندنا. قال الراجز : لراء لما رأت زُويجه زئجيلا

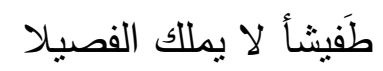

وجعله الثعالبي (') من الفارسية. وقال البستاني(†):" الزنجبيل: الخمر معرَّب

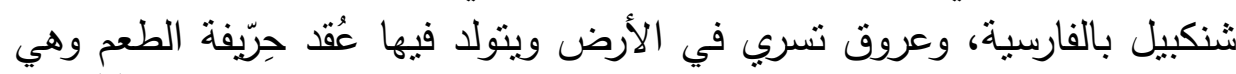

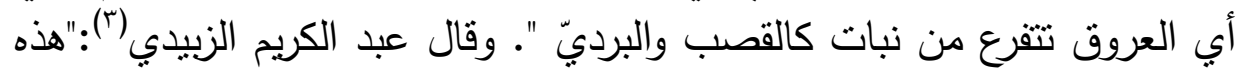

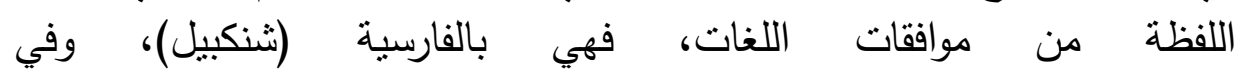

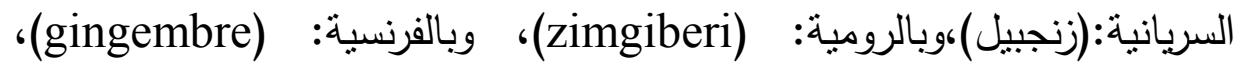

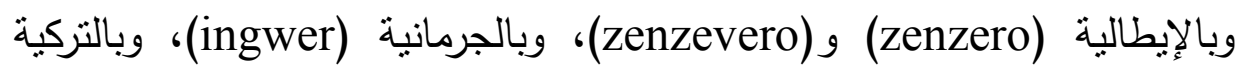
والكردية (زنجفيل)".

وقال سميح أبو مغلي في كتابه " في القرآن من كل لسان" (؛):" زنجبيل: قال

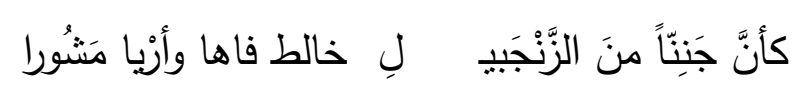

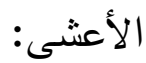

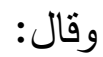

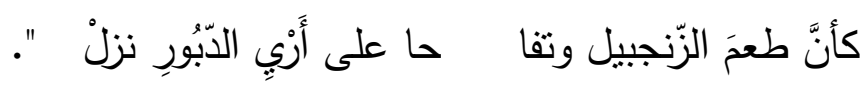

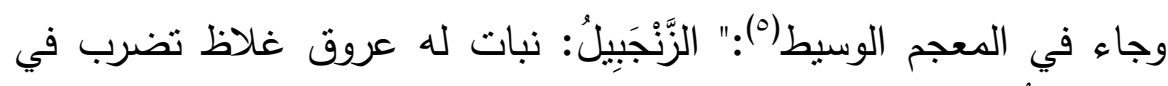

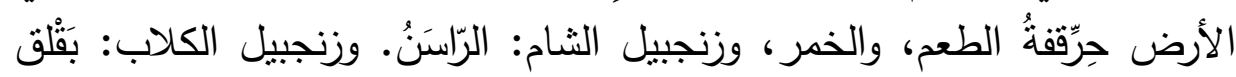
ورقها كالخِلاف وقضبانها حمرٌ ، تقتل الكلاب، ولذا أضيفت إليها ". 
أنَّ الزنجبيل نبات موجودة ومعروف في البلاد العربية وعند العرب، وقد أوضح علماؤنا قديمًا أنَّها كلمة عربية، ولا يمنع ذلك من أن أن تكون من الألفاظ

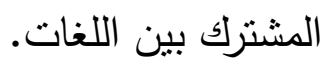

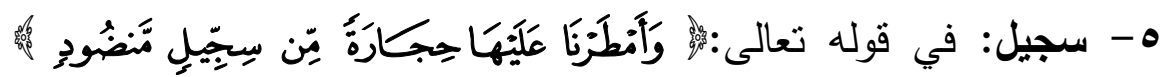

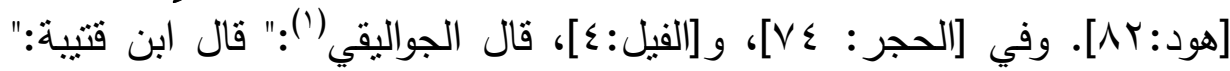

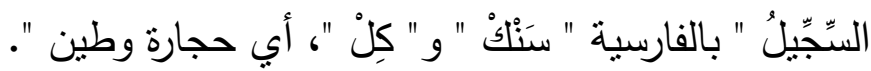

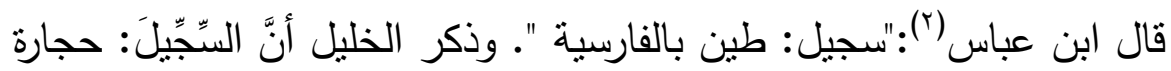

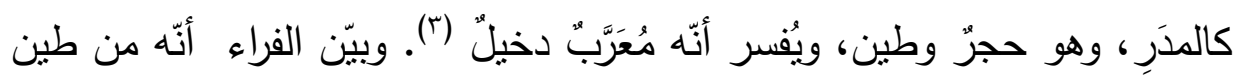

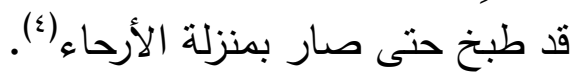

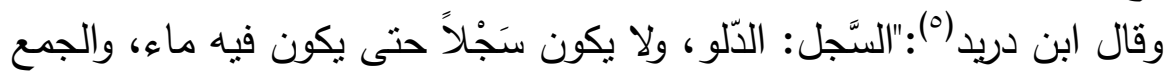

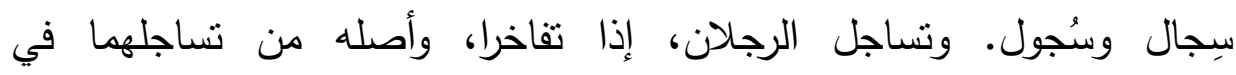

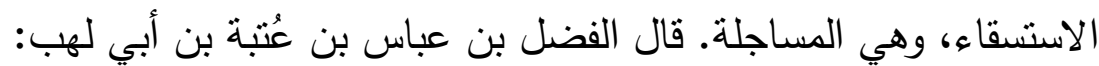

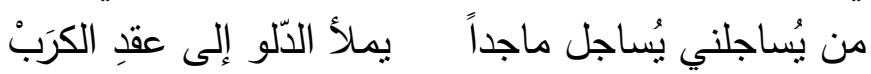

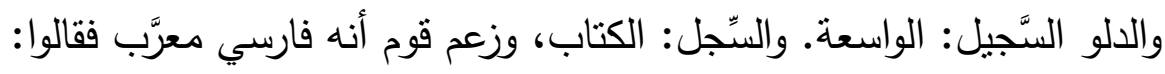

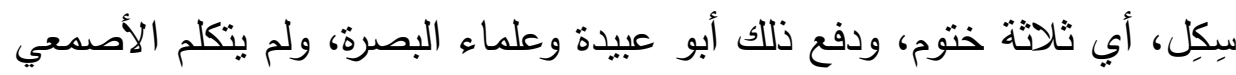

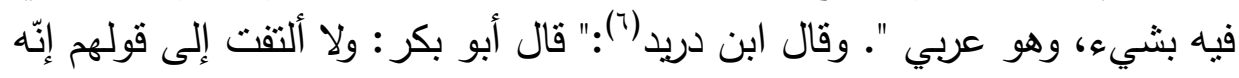

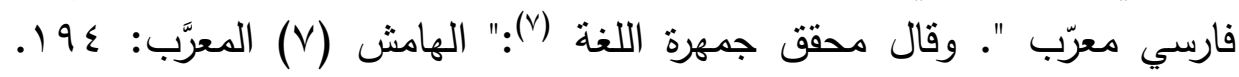

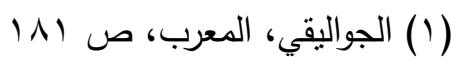

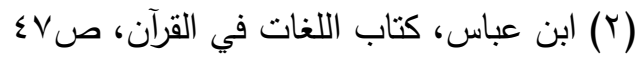

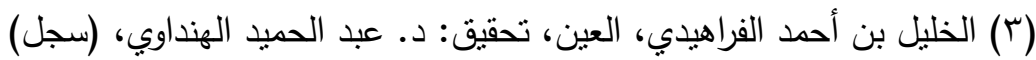

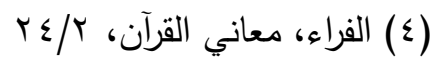

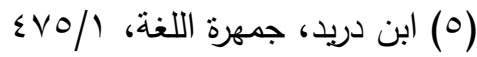

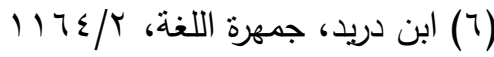

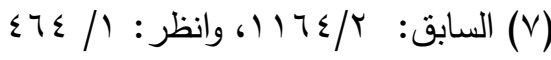


وأصل الكلمة يوناني؛ انظر: fraenkel الصلب الثديد. قال ابن مقبل:

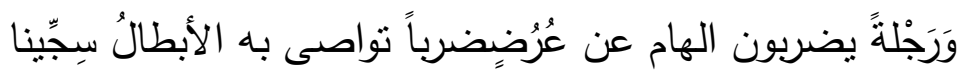

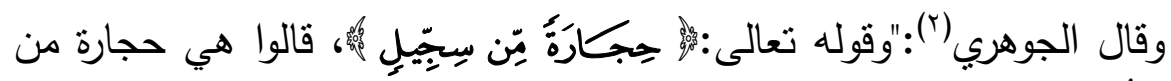

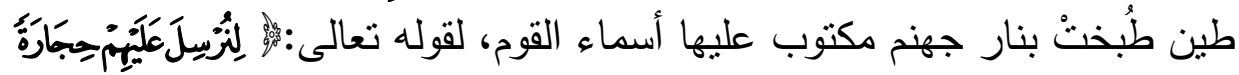

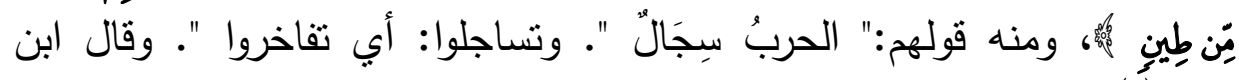

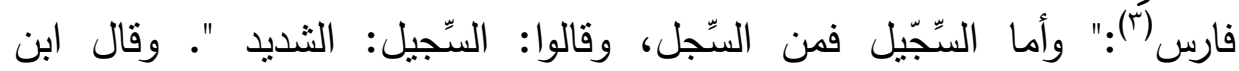

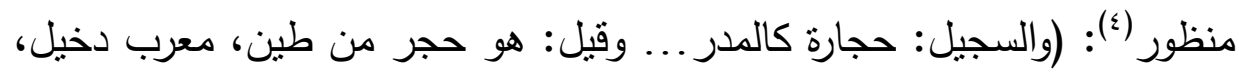

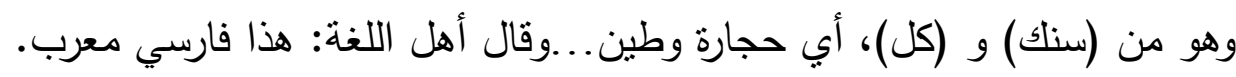

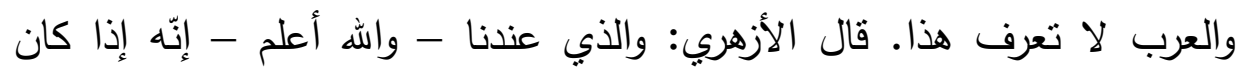

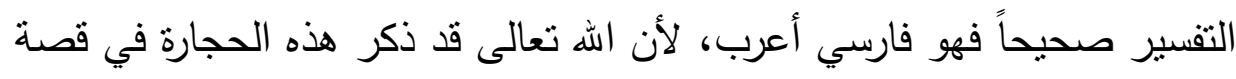

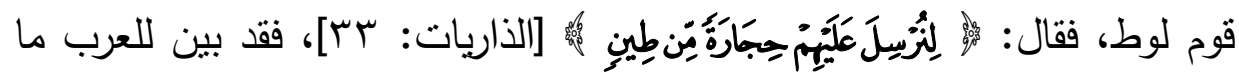

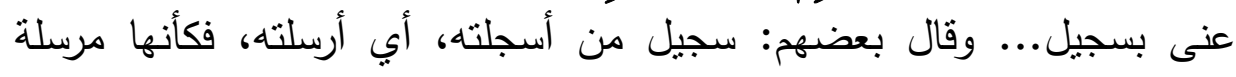

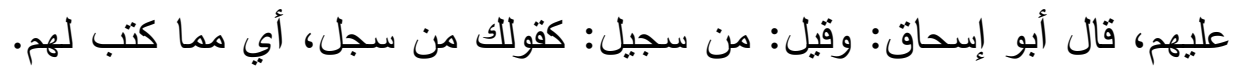

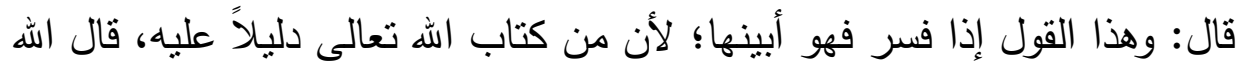

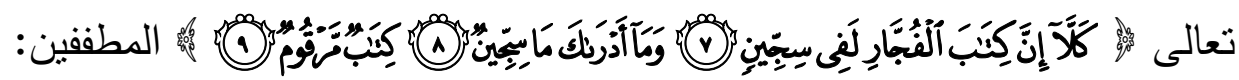

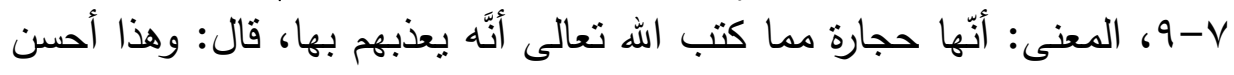

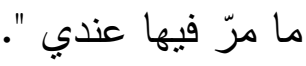
وقال السيوطي(0):" أخرج ابن أبي شيبة، عن ابن عباس في قوله تعالى:

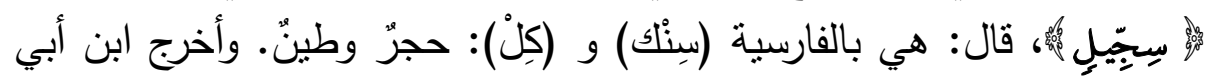

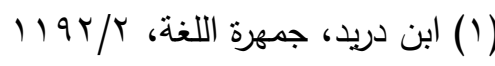

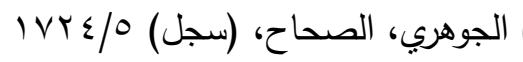

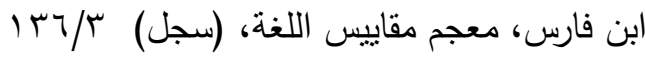

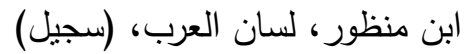

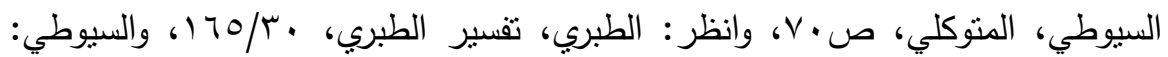

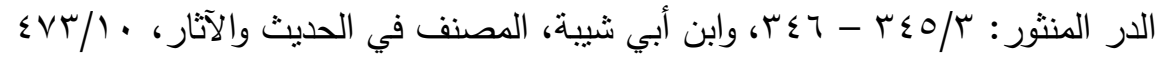




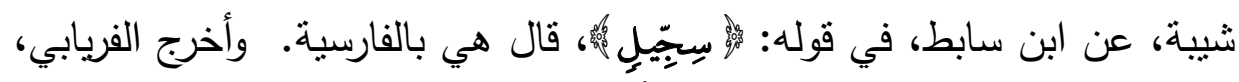

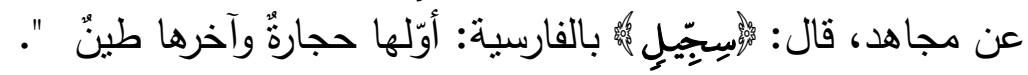

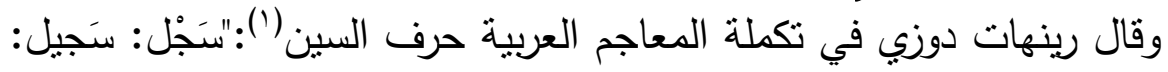

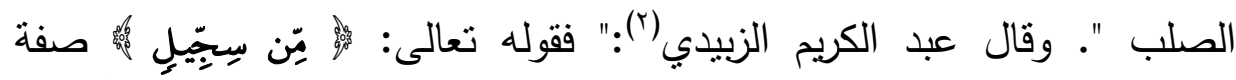

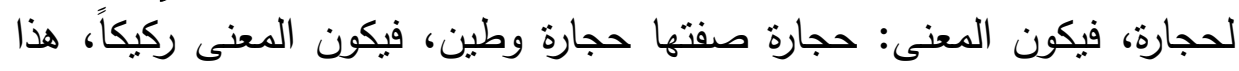

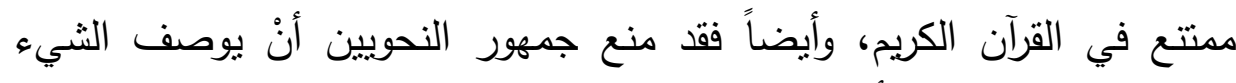

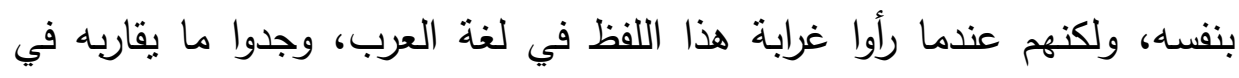

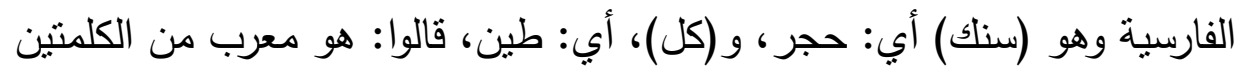

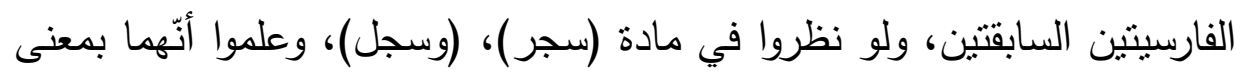

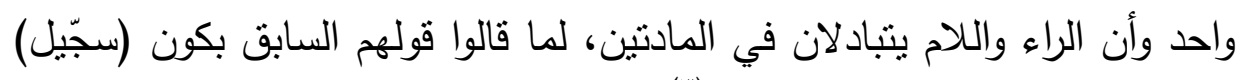

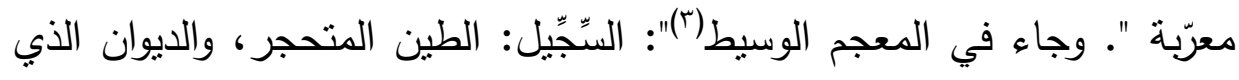

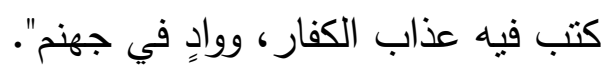

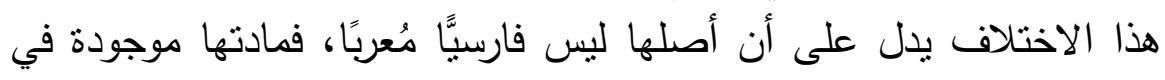

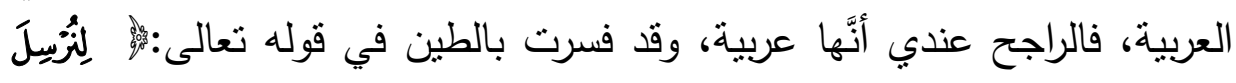

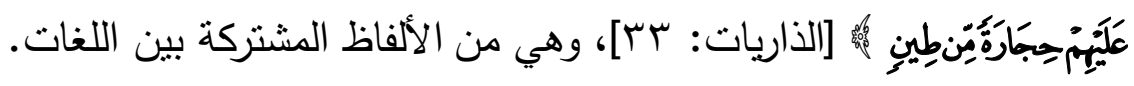

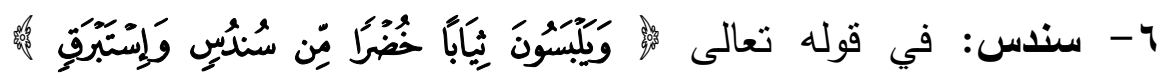

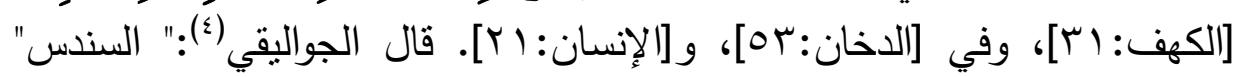

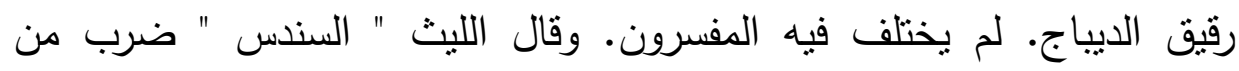

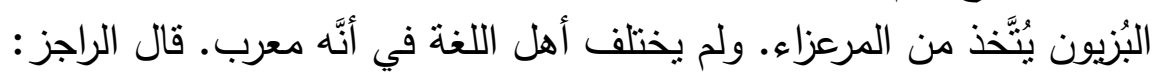

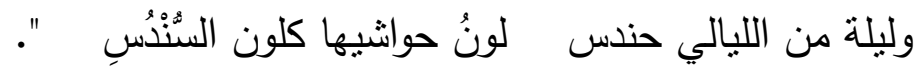

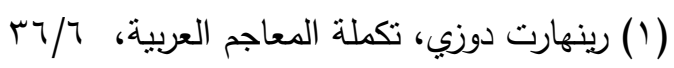

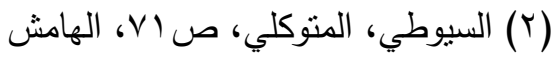

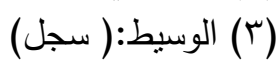

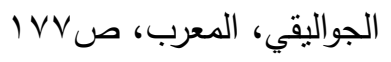




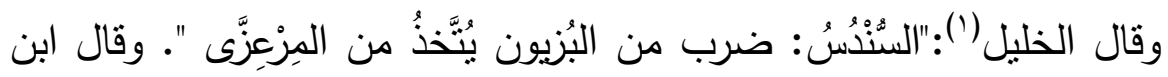
دريد(؟):" قال الثاعر : ليزيد بن الخذّاق:

فداوينُها حتى شتنت حبشيةً

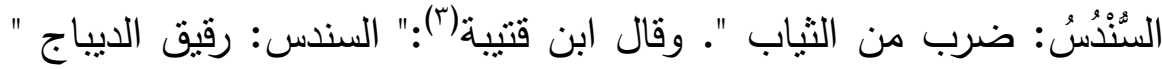

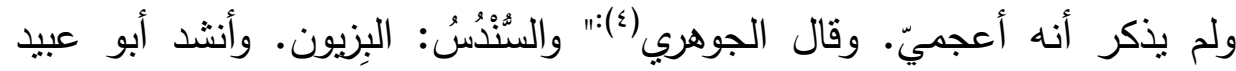

(ليزيد بن خذاق العبدي):

فداويتُها حتى شتت حبشينةًأن عليها سُنُْساً وسُدُوساً

وعده الثعالبي من الأسماء التي تقردت بها الفرس دون العرب، فاضطرت

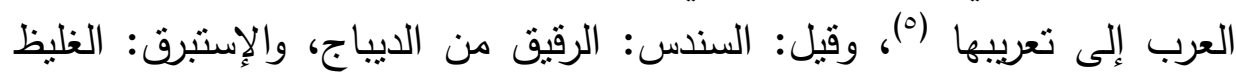
منه(؟). ولم يذكر الراغب الأصفهاني أنبه أعجمي.

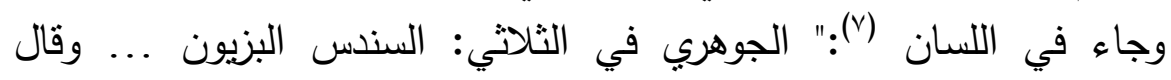

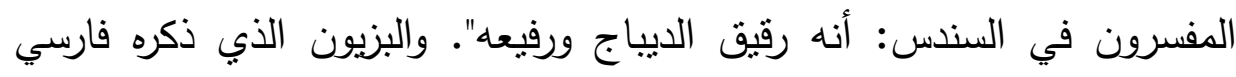

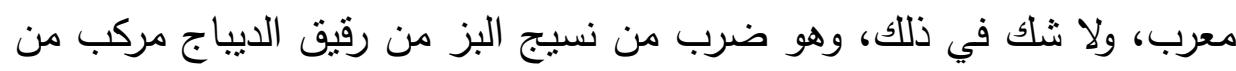
(بز) ومن (يون)، أي يشبه البز • ويون لغة في (كون) بالفارسية (^).

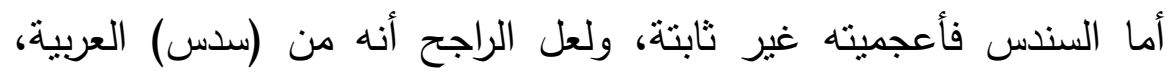
وزيدت فيه النون للمغايرة بين الخضرة والزرقة، ففي السندس زرقة تميزه، وقد تبدل السين الأخيرة راءاً فيقال: سندر، والسندري: الأزرق - وسنان سندري، إذا كان

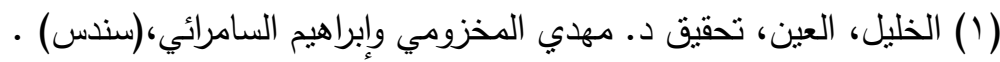

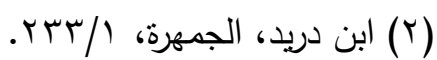

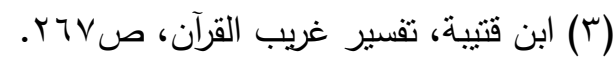

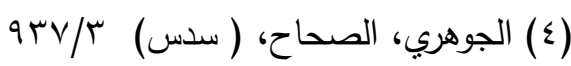

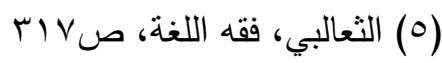

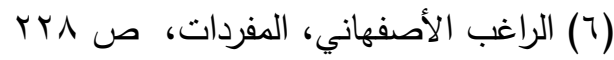

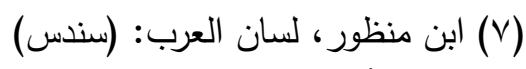
انظر : أدي شير ، معجم الألفاظ الفارسية المعربة، صنية (N) 


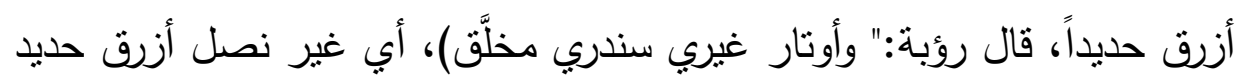

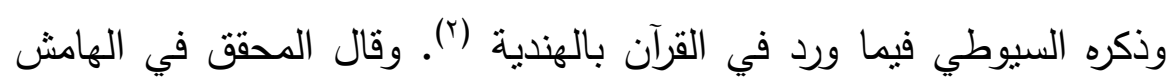

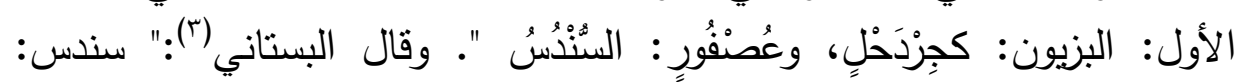

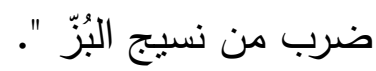

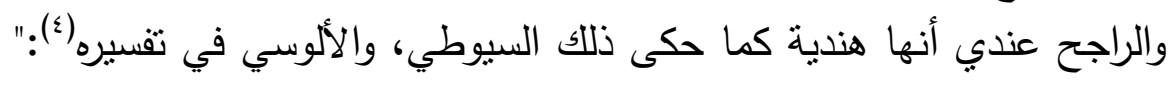

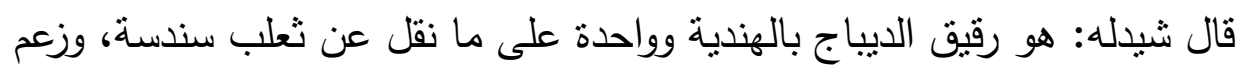

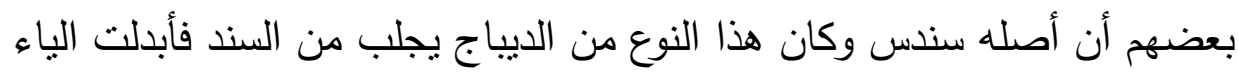

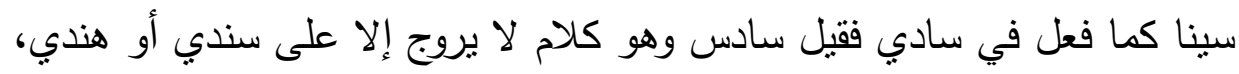

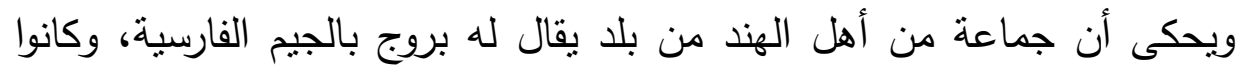

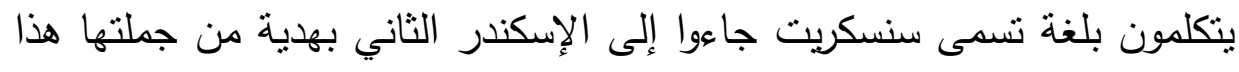

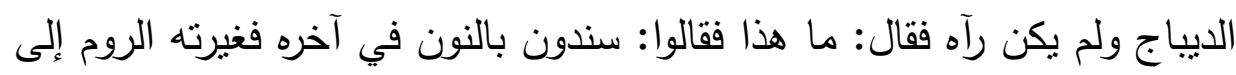

$$
\text { سندوس ثم العرب إلى سندس فهو معرب قطعا. }
$$

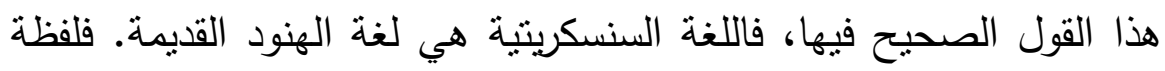

$$
\text { (سندس) هندية، استعملها الفرس والروم والعرب. }
$$

V- " سينينُ " قال الجواليقي (0): و" سينينُ " الذي ذكره الله تعالى في قوله:

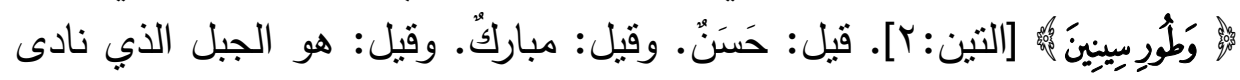

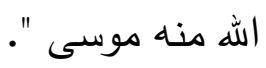
وذكر الخليل أنَّ وطورِ سيناء: جبل. وسينين: اسم جبل بالثثّام ('). ولم يذكر

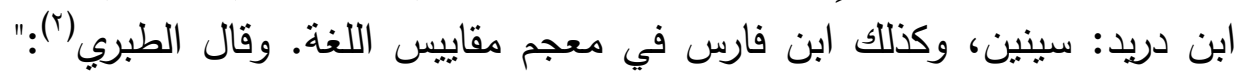

$$
\begin{aligned}
& \text { () انظر : ابن منظور، لسان العرب، (سندر) }
\end{aligned}
$$

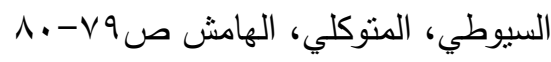

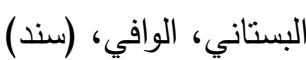

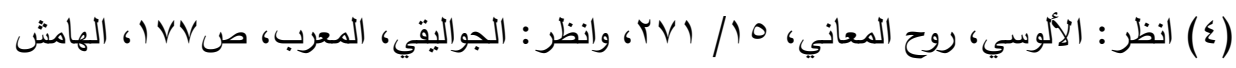

(الجواليقي، المعرب، ص1911 


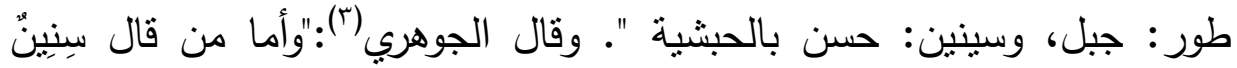

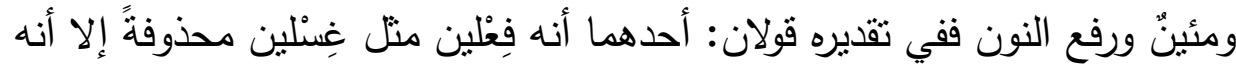

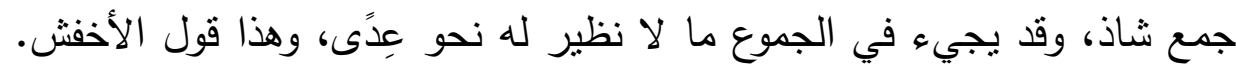

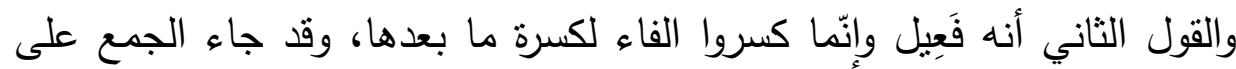

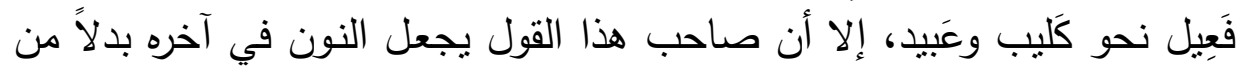

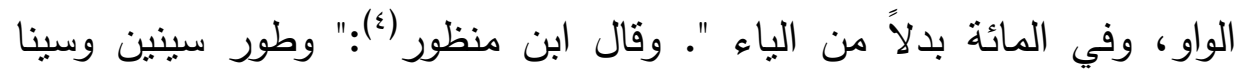

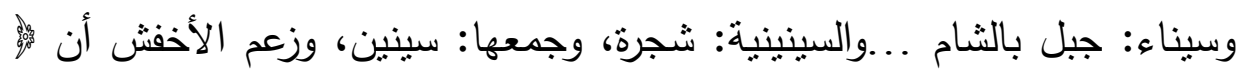

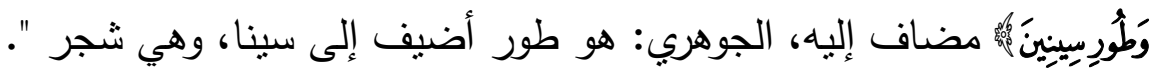

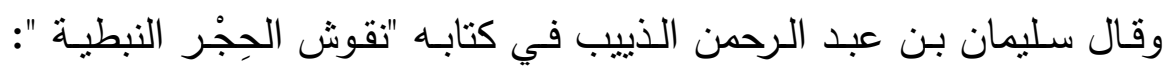

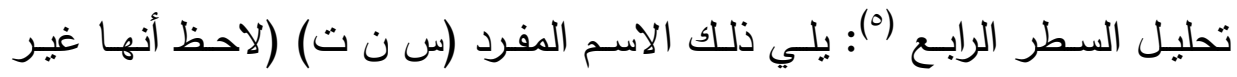

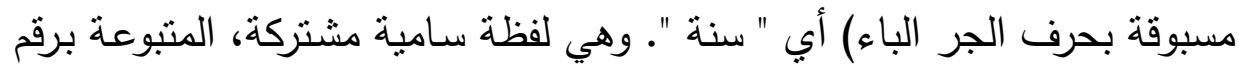

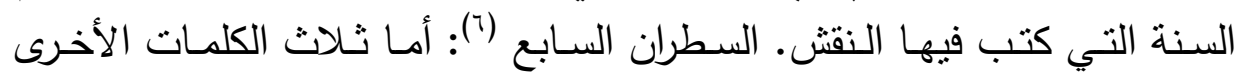

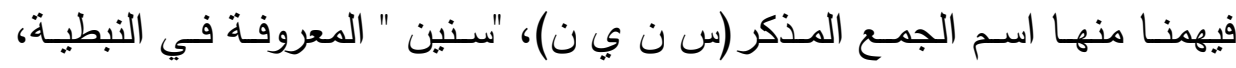

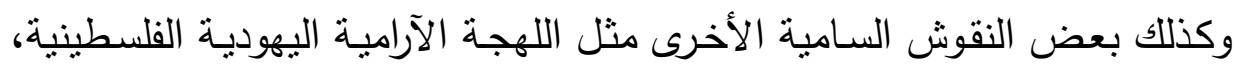
والآرمية الفلسطينية، والسريانية والعبرية.

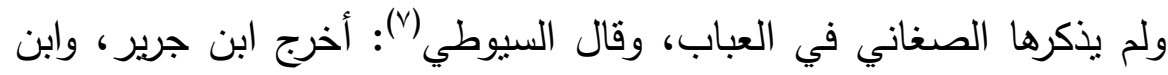

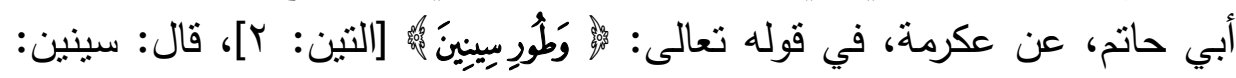

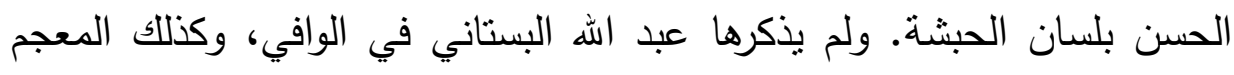
الوسيط.

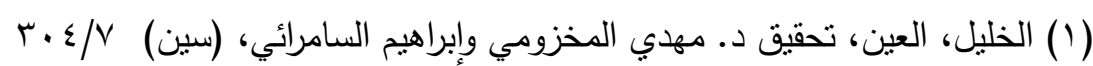

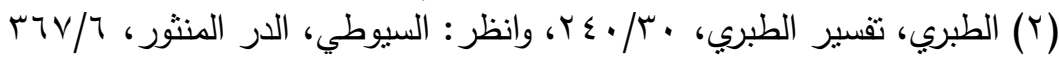

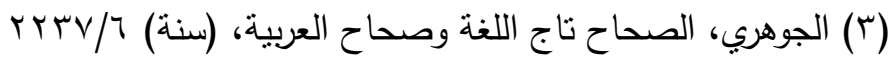

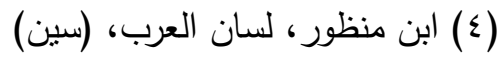

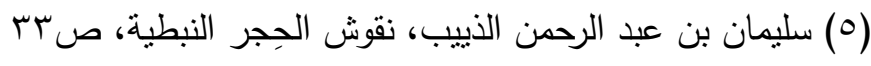

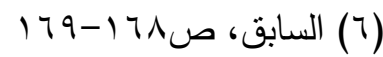

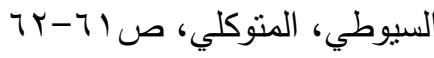




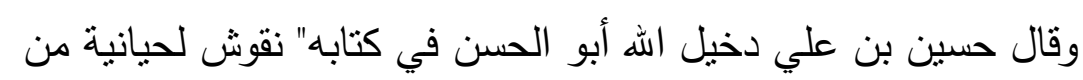

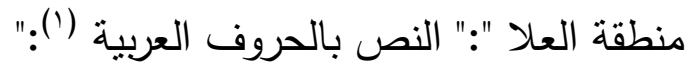

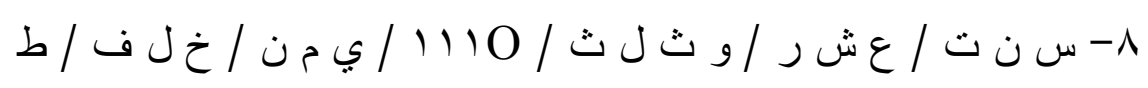

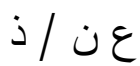

قراءة النص:السطر م- دنة ثلاثة عشر يوم طعن خلف ذو ".

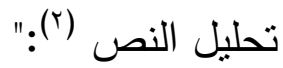

^- س ن تائ (سنة) أب عام وترد هذه الكلمة كثيراً في النقوش اللحيانية

المؤرخة بسنوات حكم ملوكهم ".

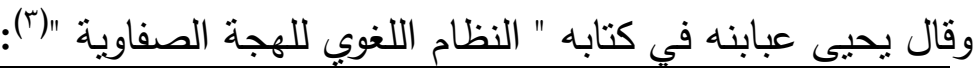

\begin{tabular}{|c|c|c|c|c|}
\hline العربية الجنوبية & الثمودية & العربية & الصفاوية & الجذر \\
\hline- & snt & سنة & snt & snw \\
\hline
\end{tabular}

وإذا صحح أنَّ " سينين " بالحبشية: الحسن، فمادتها موجودة في العربية، نقلها

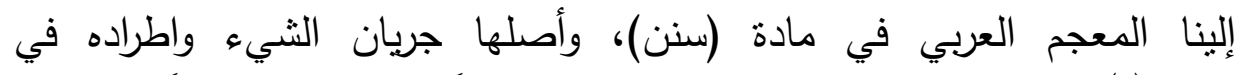

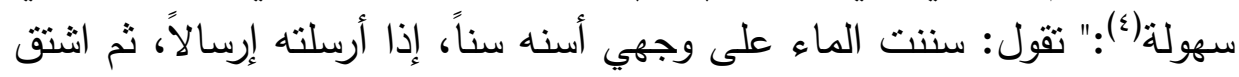

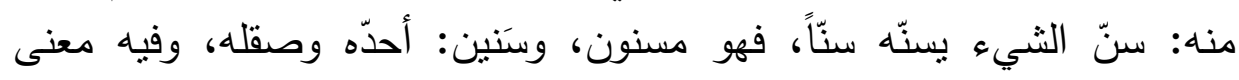

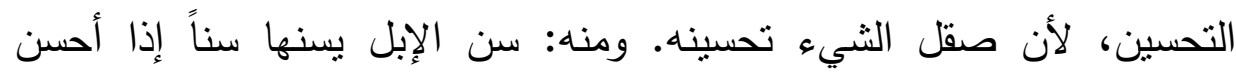

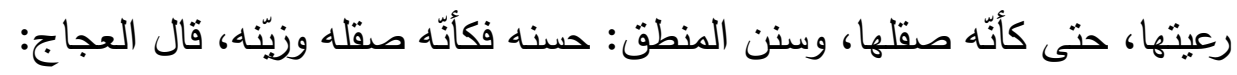

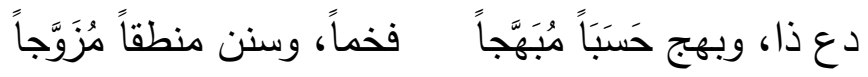

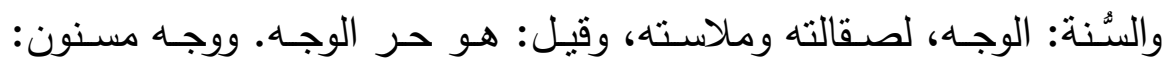

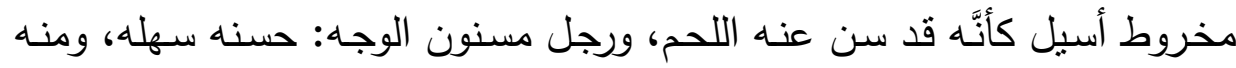

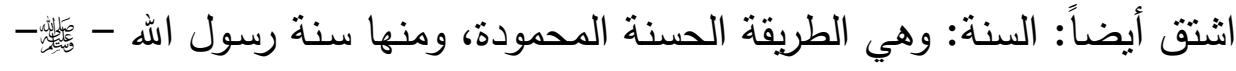

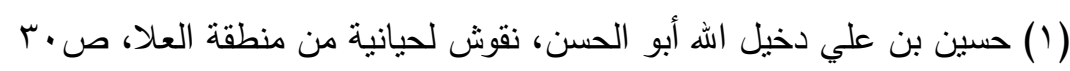

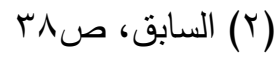

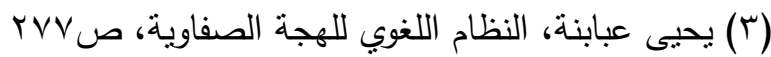

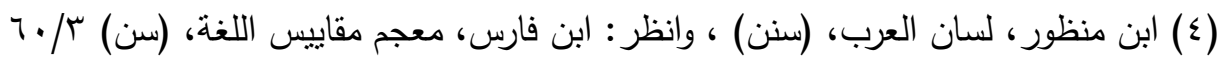

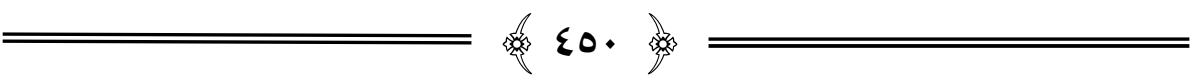




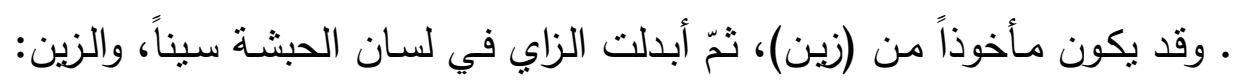

$$
\text { الحسن، وهو خلاف (الثين). }
$$

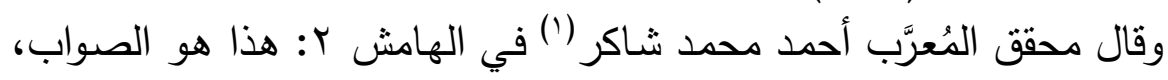

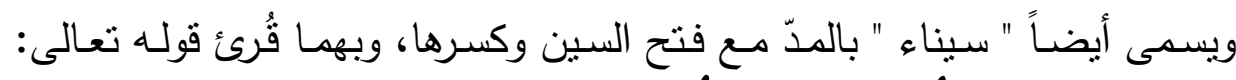

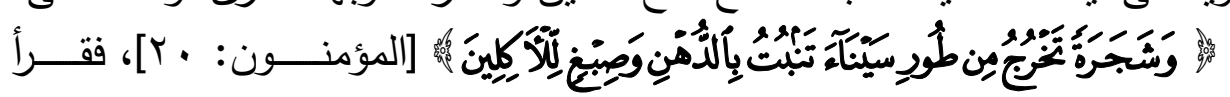

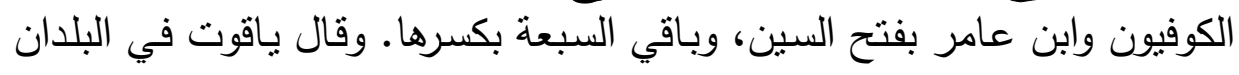

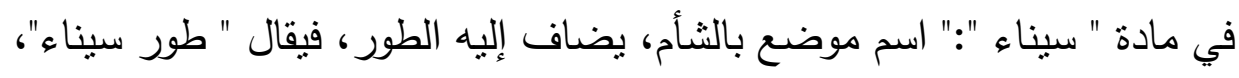

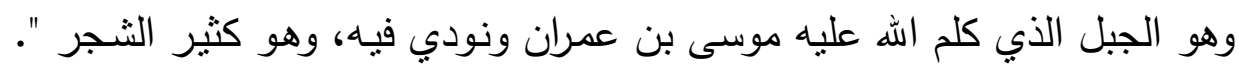

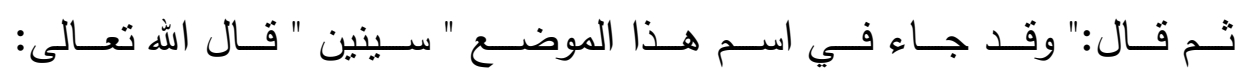

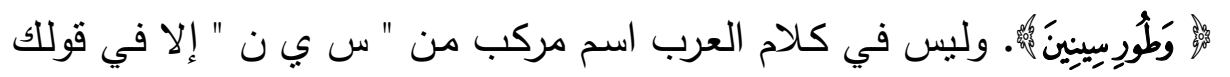

$$
\text { في الحرف " سين". }
$$

وأقول بعد النظر في " سينين ": إنَّها لفظة سامية مشتركة كما قال سليمان

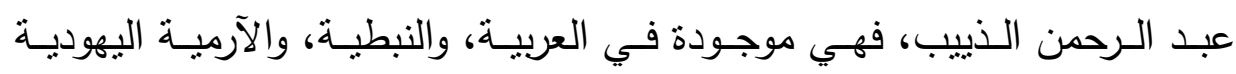

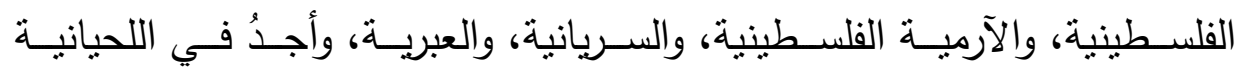

$$
\text { والصفاوية والثمودية سنة. }
$$

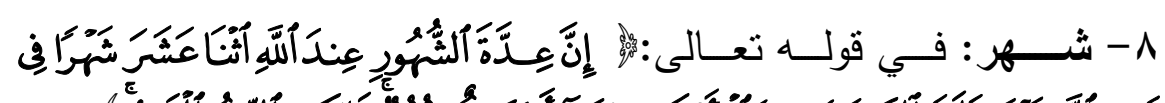

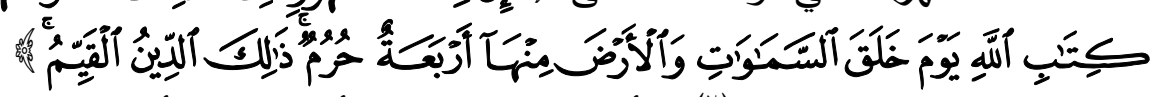

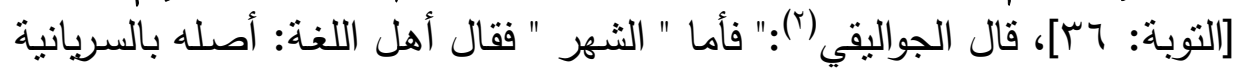

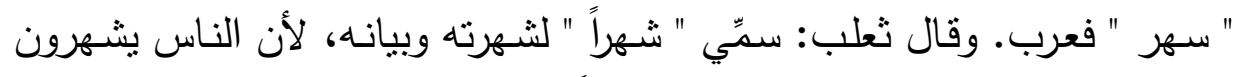

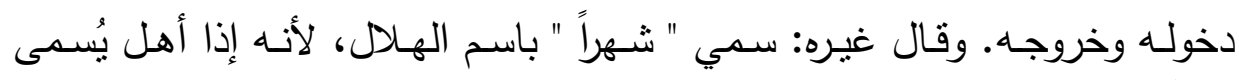

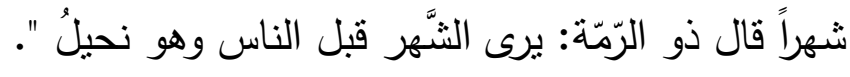

(1) الجواليقي، المعرب، الهامش الثاني ص19 1. وانظر: باقوت الحموي، معجم البلدان،

$$
r \cdot r
$$

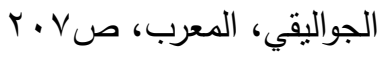


وقال الخليل('):" الثهر والأشهر عدد، والثهور جماعة. والمشاهرة: المعاملة

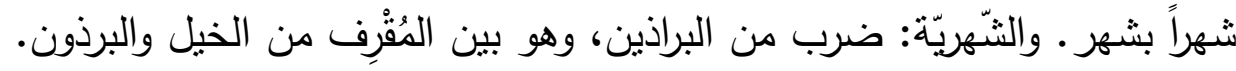

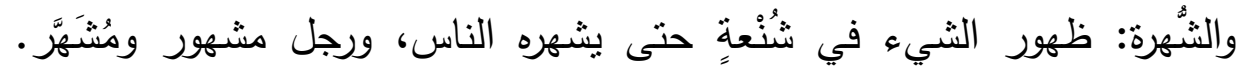

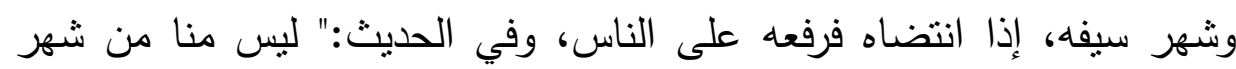

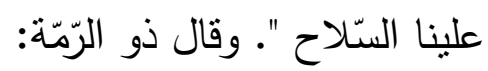

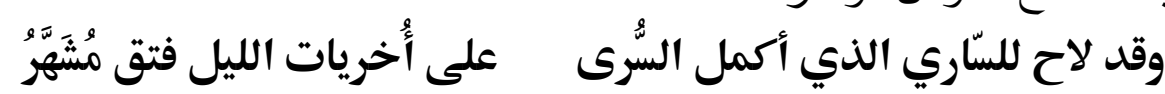

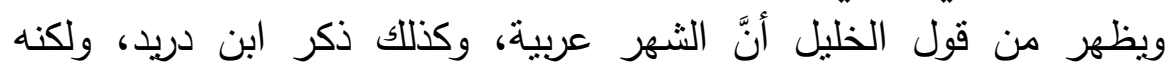

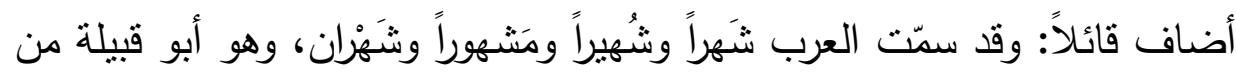

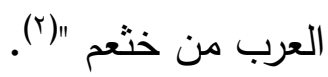

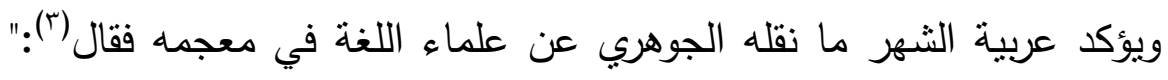

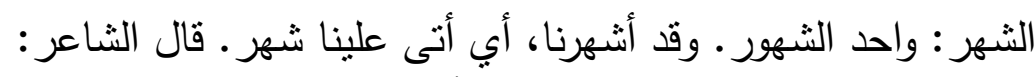

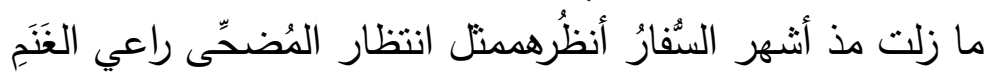

ابن السكيت: أنشهرنا في هذا المكان: أقمنا فيه شهراً، وقال ثعلب: أشهرنا:

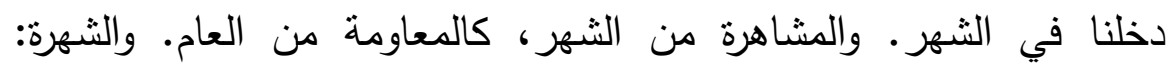

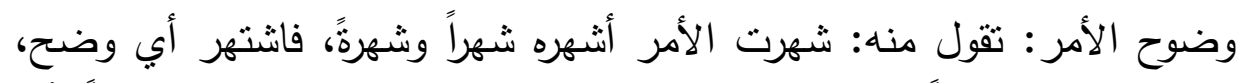

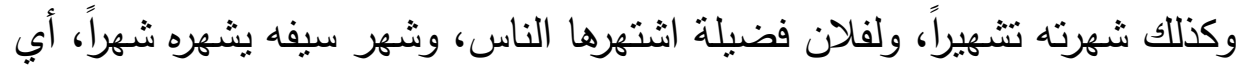
سلَّه ".

وقال ابن منظور (§): الثهر : القرر، سمي بذلك لثهرته وظهوره، وقيل: إذا

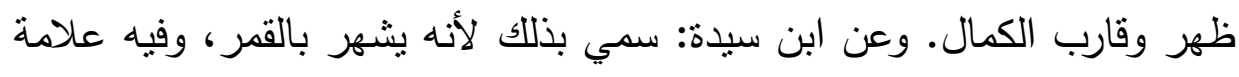

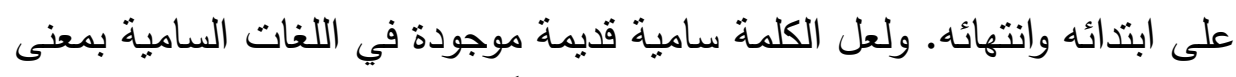

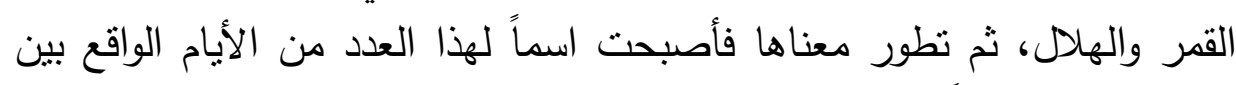

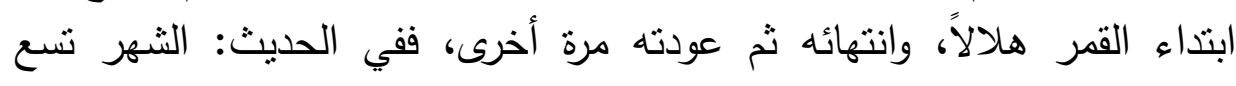

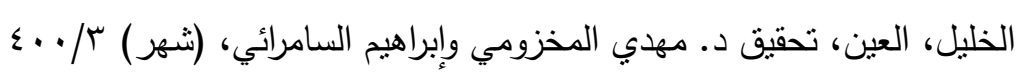

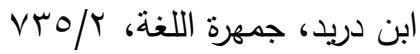

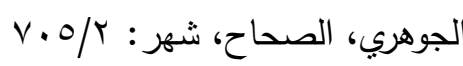

$$
\begin{aligned}
& \text { ابن منظور ، لسان العرب، (ثهر ) }
\end{aligned}
$$




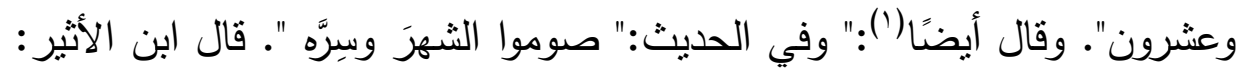

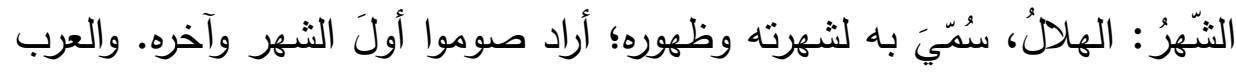

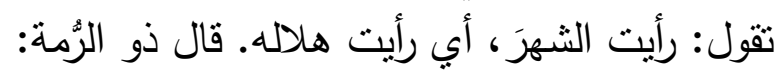

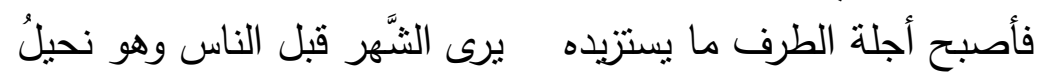

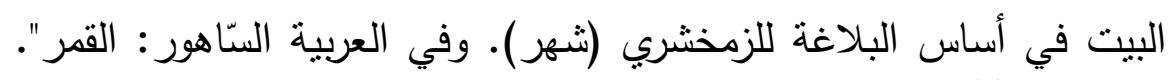

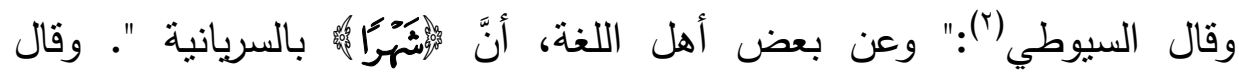

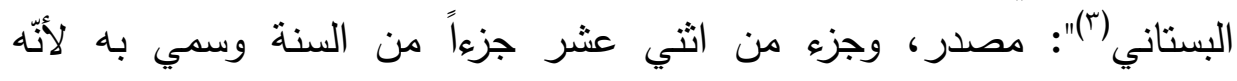

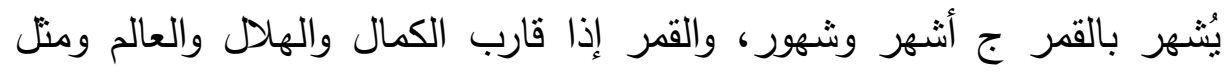

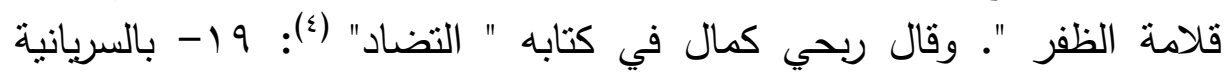

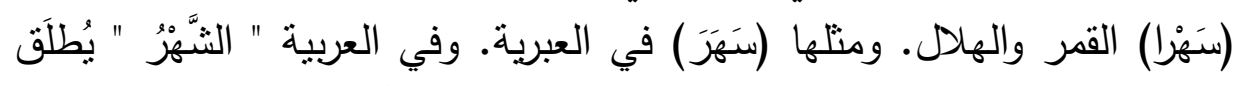

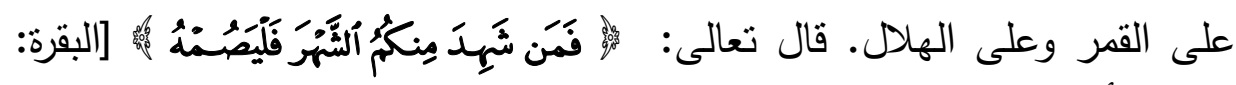

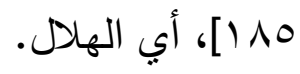

وقال يحيى عبابنة (o)" yrh شهر (ورخ) شهر قمري، قمر - في الكنعانية- ".

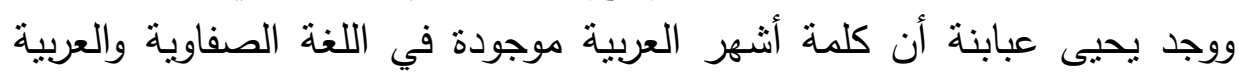

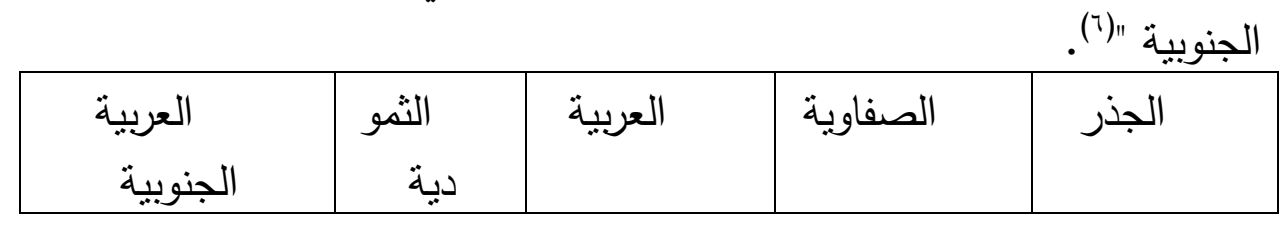

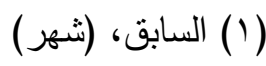

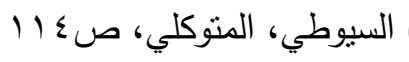

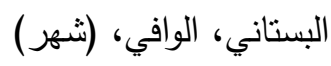

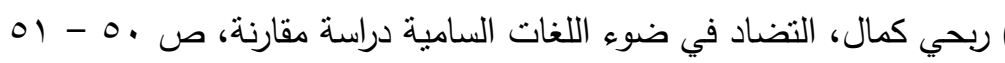

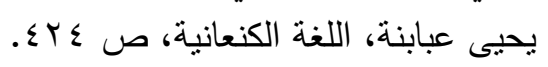

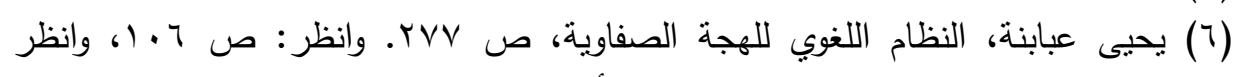

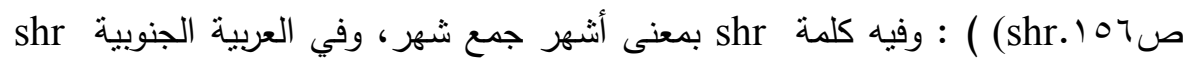
بالسين بداية الثهر . 


\begin{tabular}{|l|l|l|l|l|}
\hline Shr & -- & أتثهر & shr & shr \\
\hline
\end{tabular}

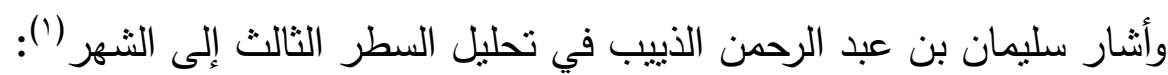

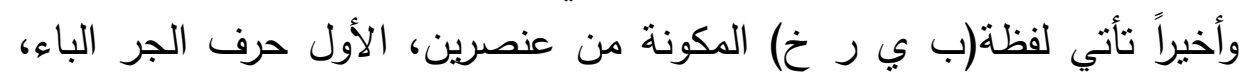

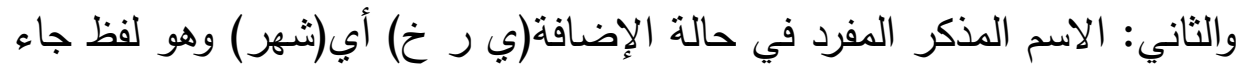
في الأوجاريتية والفنيقية. وجاء في الوسيط (†):" الثََّّهُ : جزء من السنة القمرية يقدَّر بدورة القمر حول

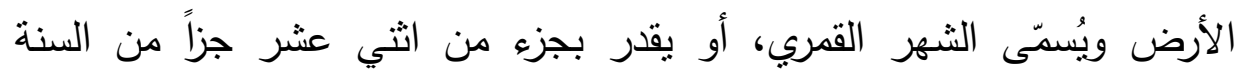

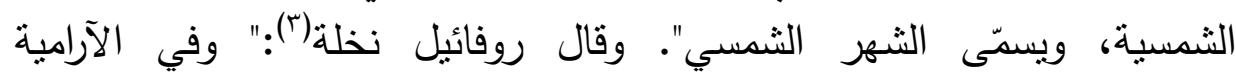
والسريانية (سها) أي القمر ، أو شهر قمري".

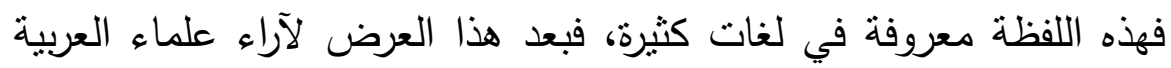

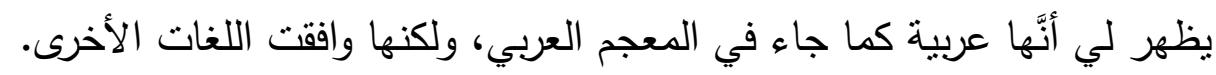

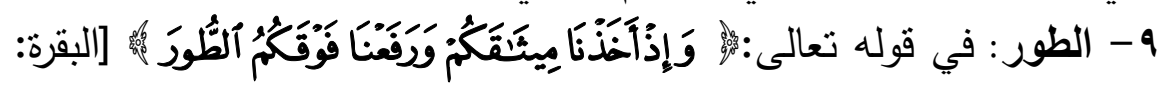

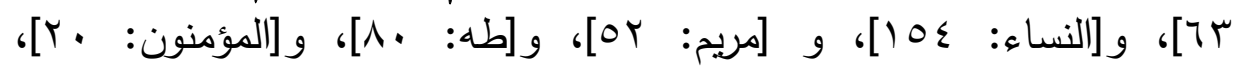

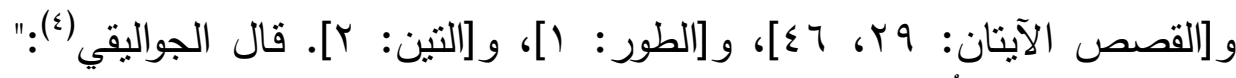

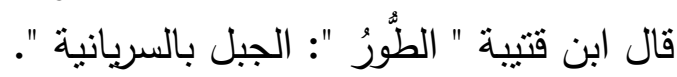

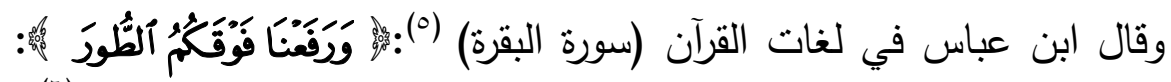

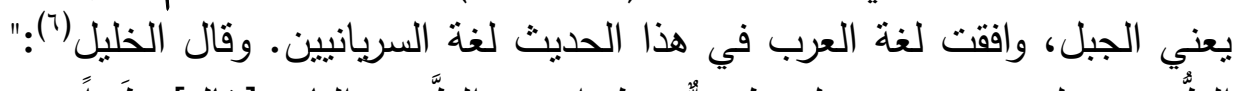

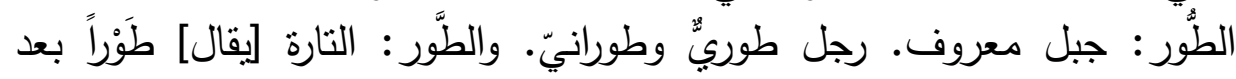

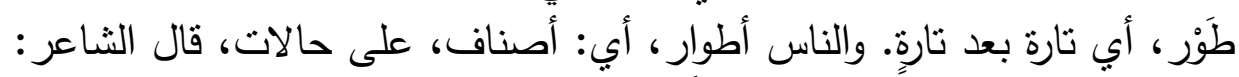

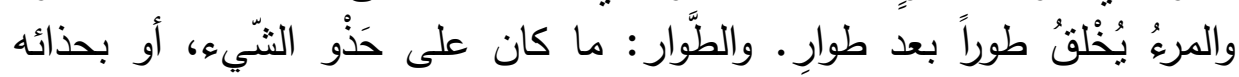

$$
\begin{aligned}
& \text { ( (1) سليمان بن عبد الرحمن الذيبب، نقوش الجِجْر النبطية، صست }
\end{aligned}
$$

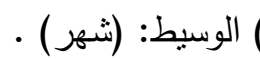

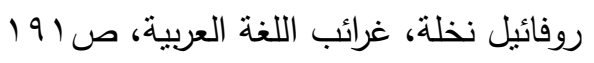

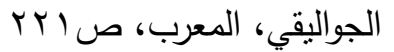

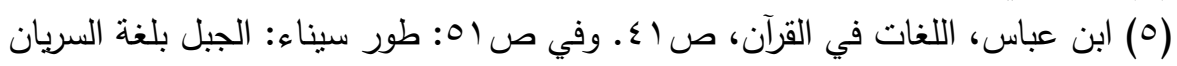

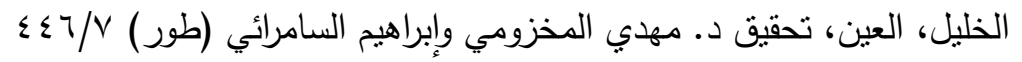




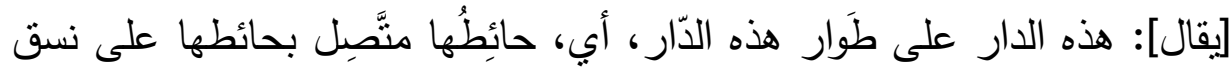

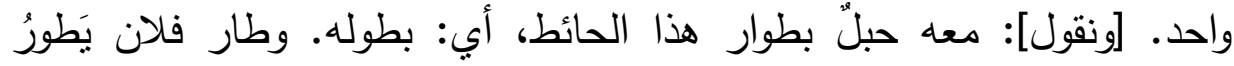

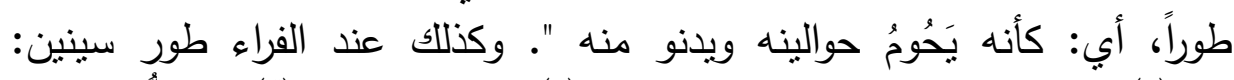

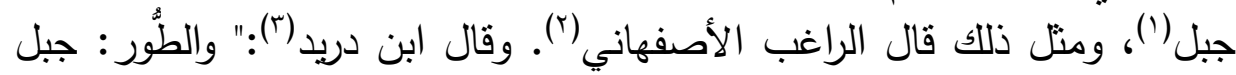

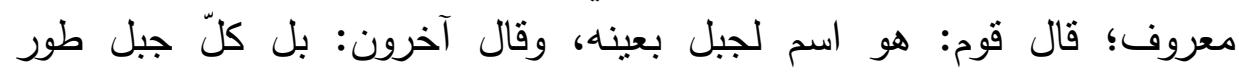

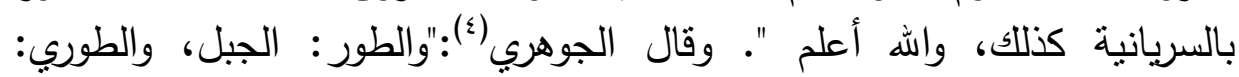

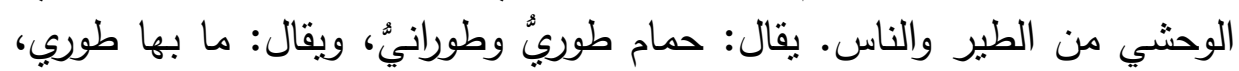

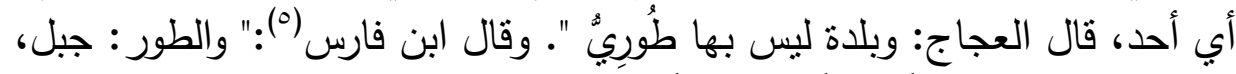

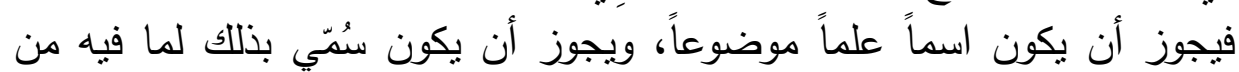

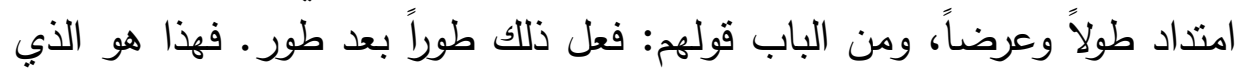

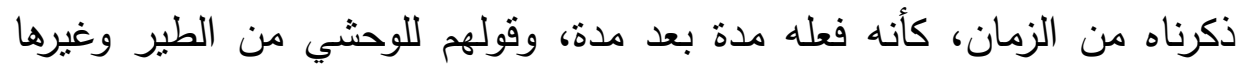

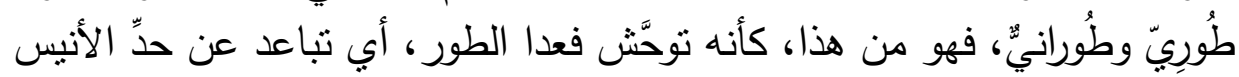

وقال ابن منظور (־):" طور الدار : ما امتد منها من البناء. ويقال: هذه الدار

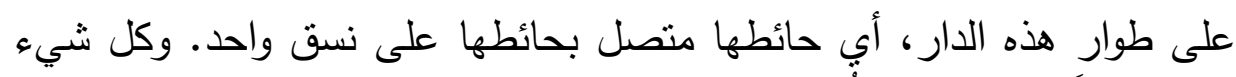

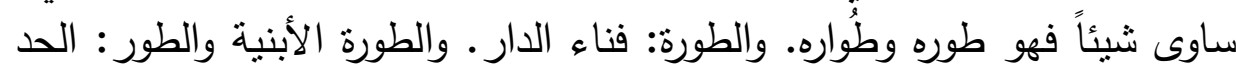

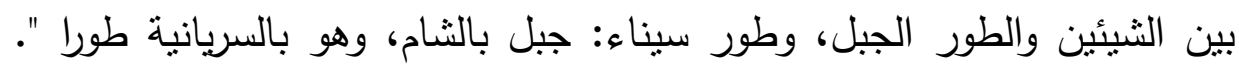

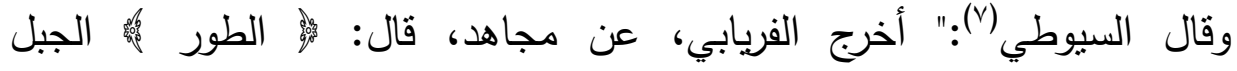

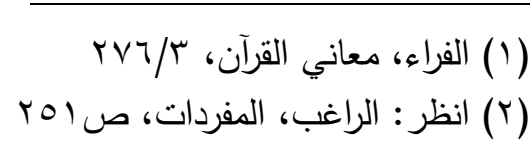

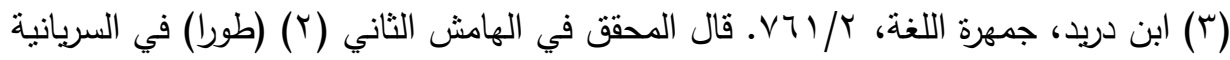

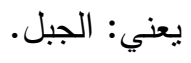

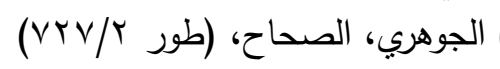

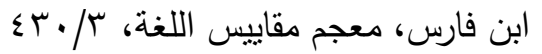

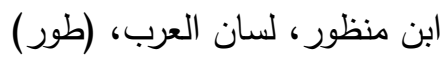

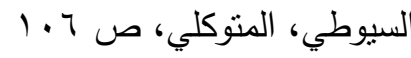


بالسريانية". وذكر السيوطي (الطور) هنا على أنها من السريانية، وذكرها مرة

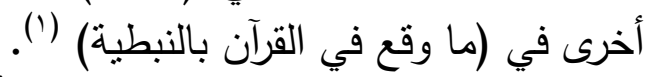

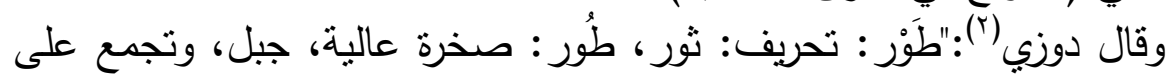

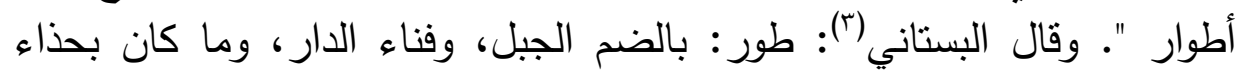

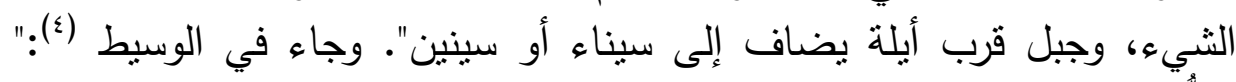

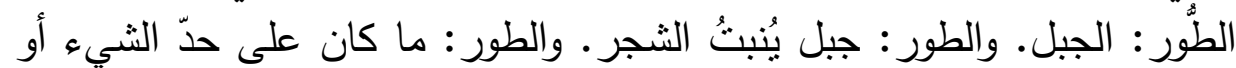

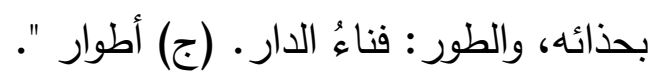

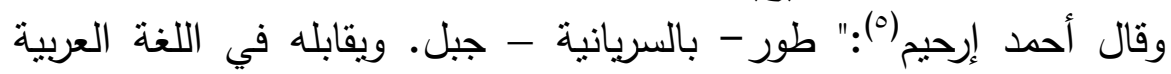

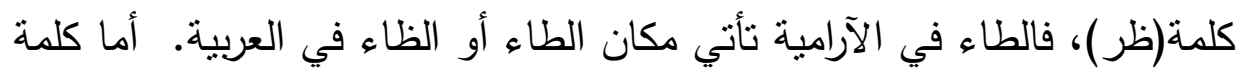

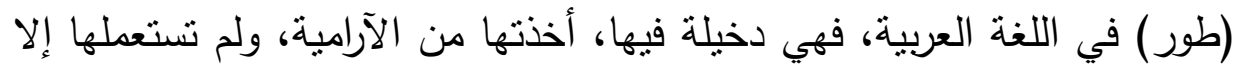

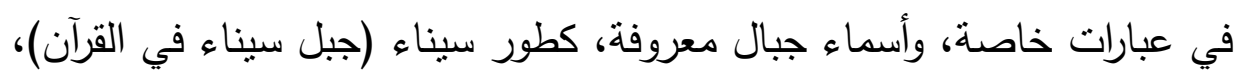
وطور عابدين ". والمعجم العربي يقرر أن اللفظة عربية قد وافقت السريانية أيضاً. وليس فيما قاله أحمد إرحيم في أن (الطور ) سريانية يقابلها في العربية (ظر ) أب دليل، فمادية

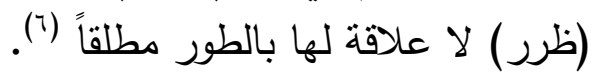
وهذه اللفظة عربية كما ذكر علماء لألعاء العربية في معاجمهم، وافقت اللغات

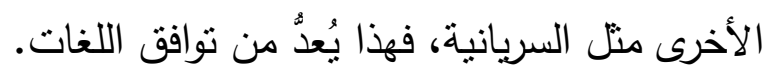

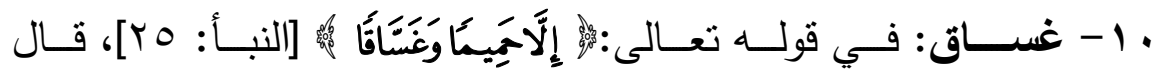

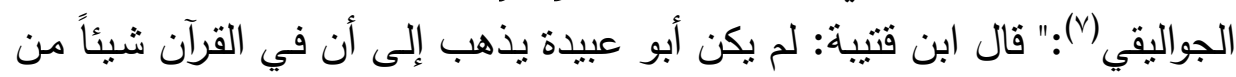

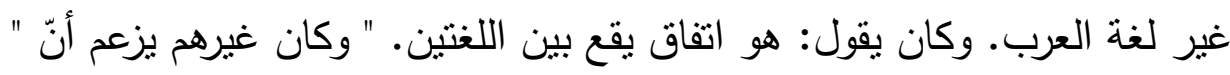

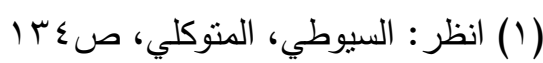

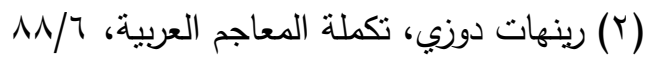

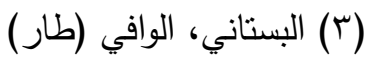

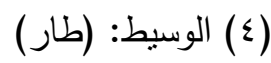

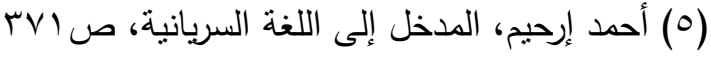

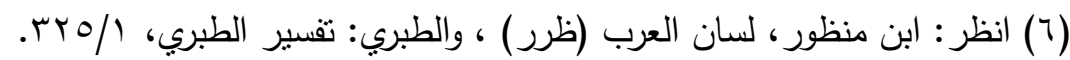

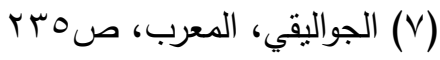




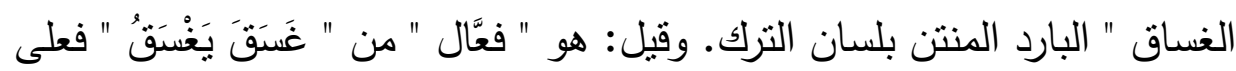

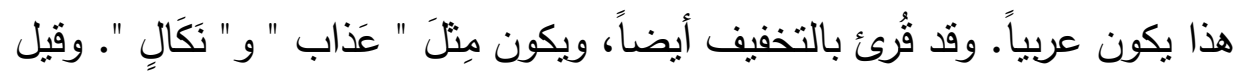

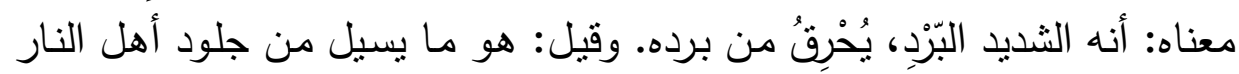
من الصديد ".

قال الخليل ('):"الغاسقُ: الليل إذا غاب الثفقُ. وغسقت عينه تغسق غُسوقاً

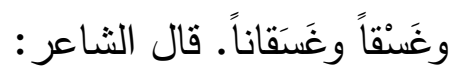

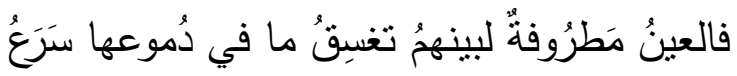

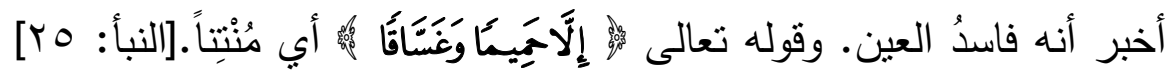

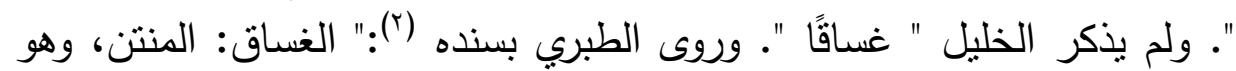

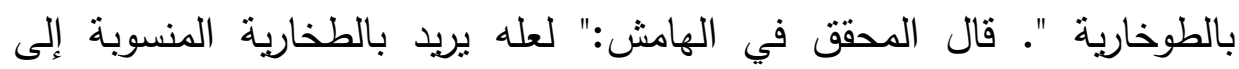

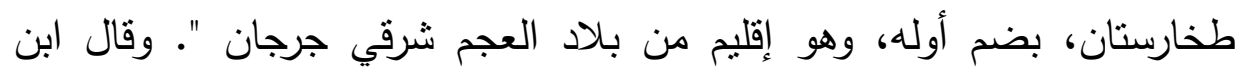

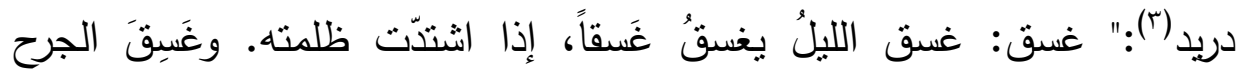

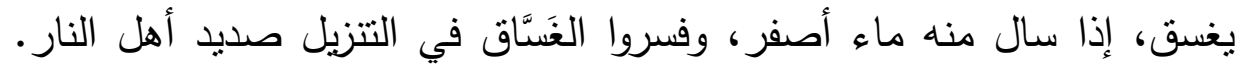

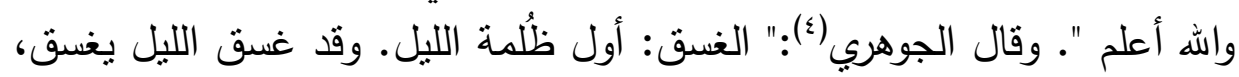

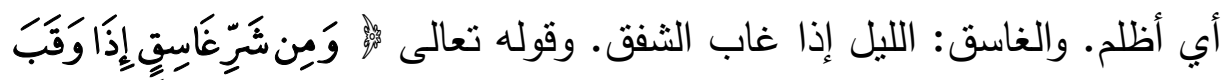

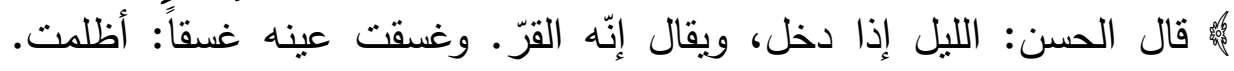

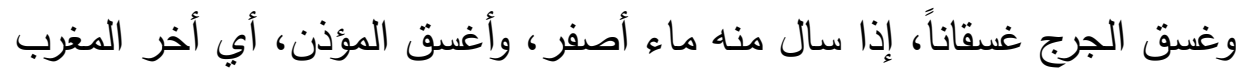

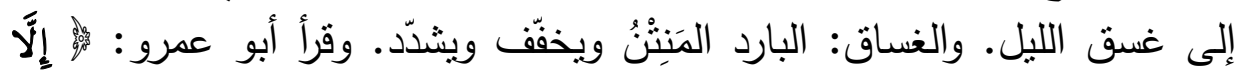

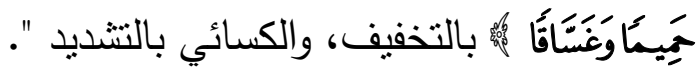

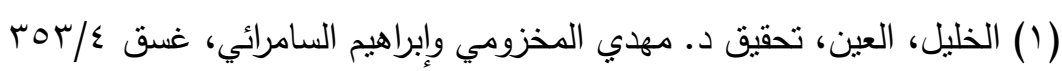

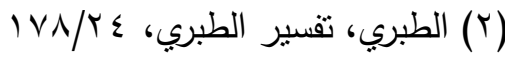

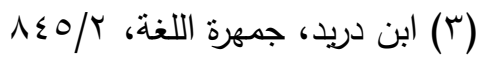

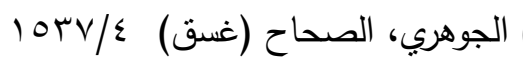




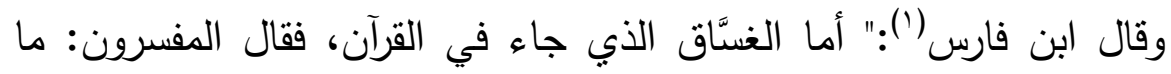

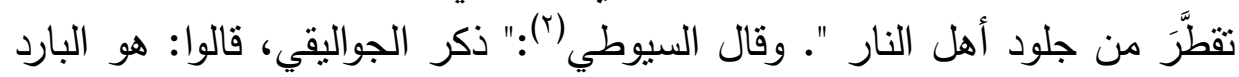

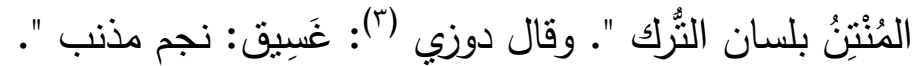

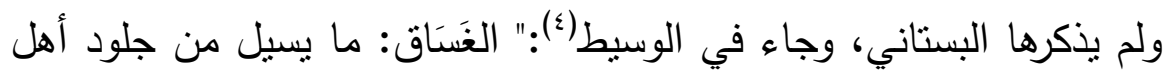

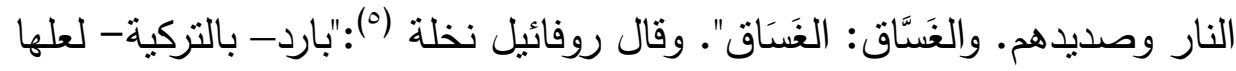
من (soghouk)" (s) وأرى أنَّ العلماء السابقين يجمعون على أنَّها تركية، وقد تكون من نوافق

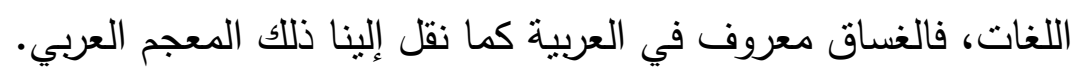

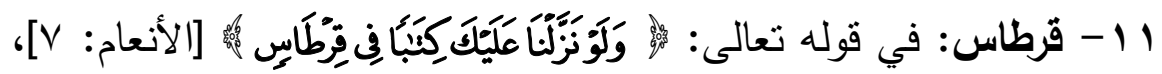

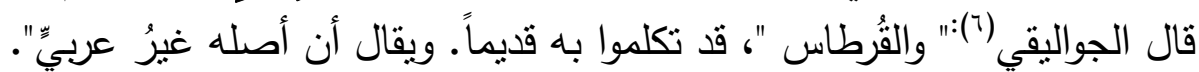

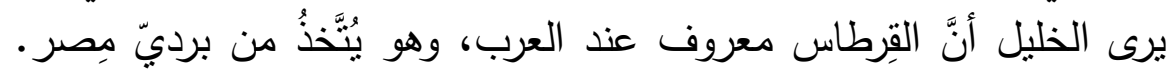

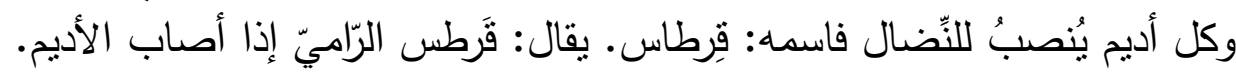

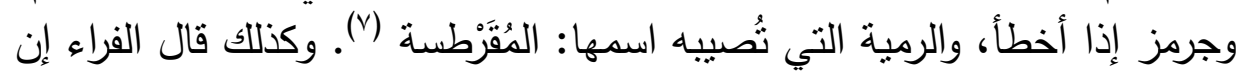

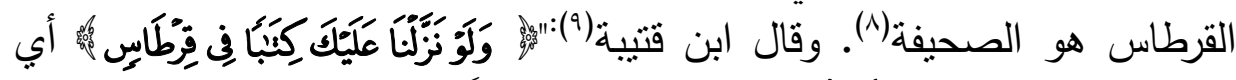

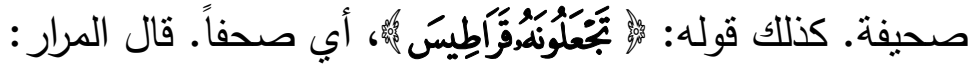

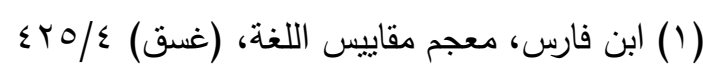

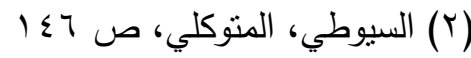

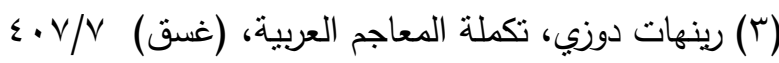

$$
\begin{aligned}
& \text { (ع) الوسيط: غسق }
\end{aligned}
$$

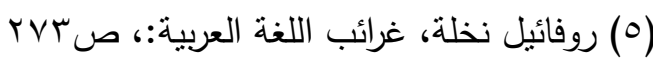

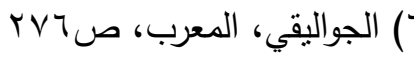

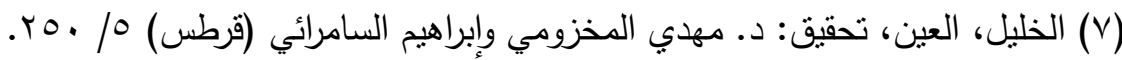

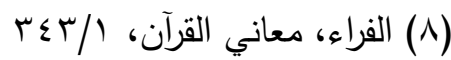

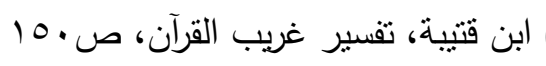




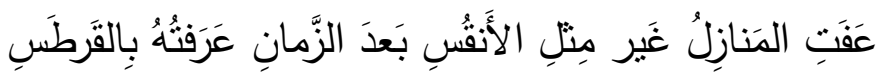

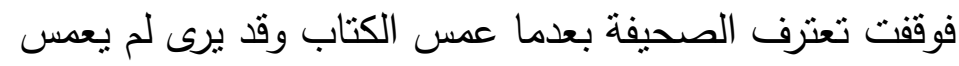

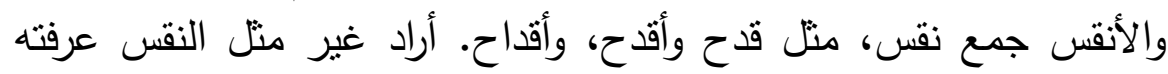

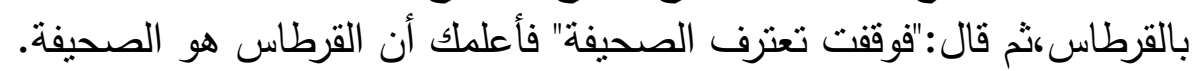

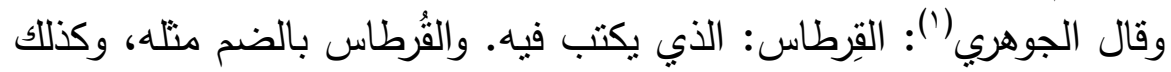

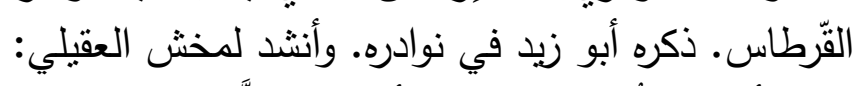

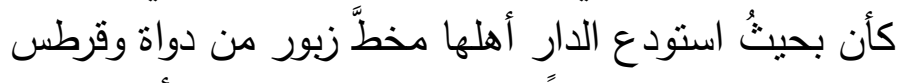

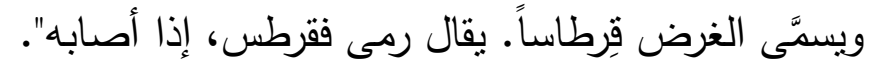

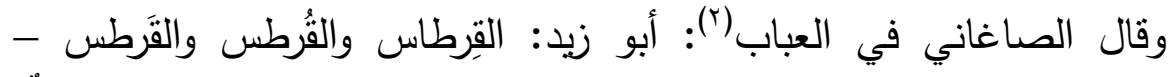

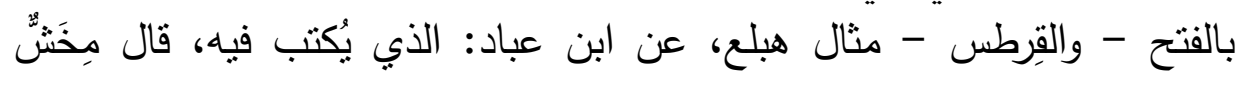

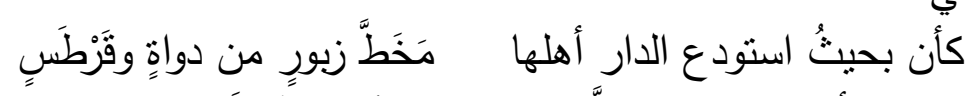

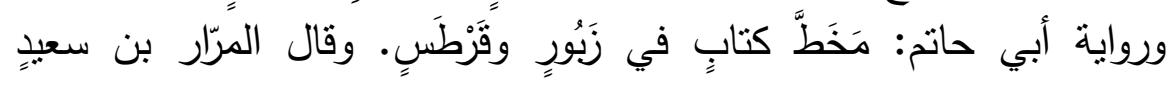

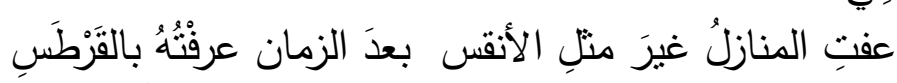
الفَقْعَبِيُّ:

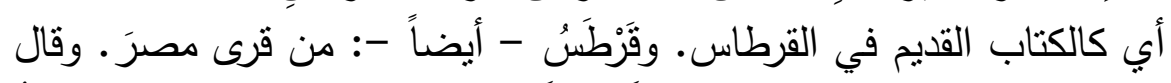

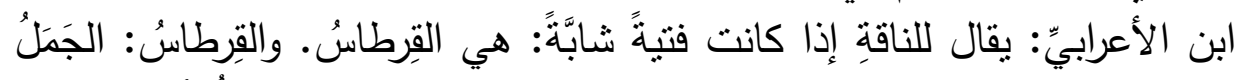

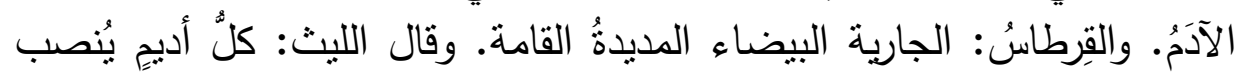

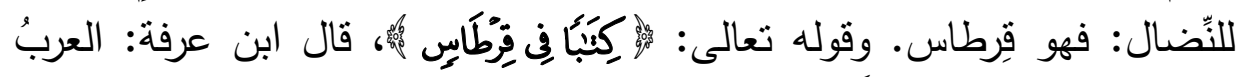

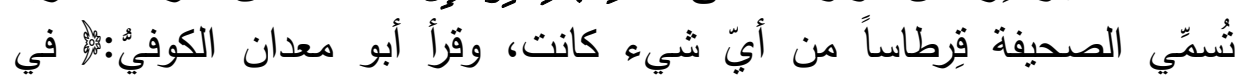

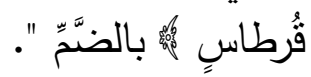

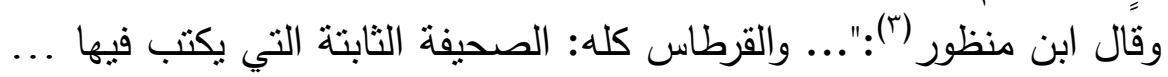

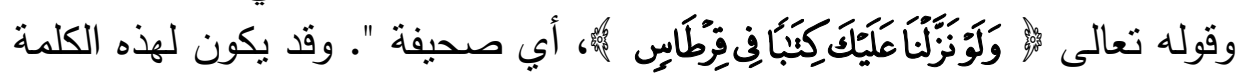

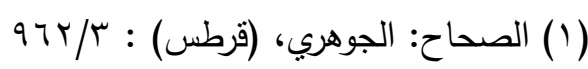

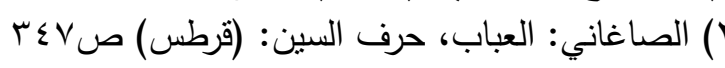

$$
\begin{aligned}
& \text { (بن ابن منظور ، لسان العرب (قرطس) العبان الترط }
\end{aligned}
$$


علاقة بـ (طرس) العربية. قال في اللسان (طرس):" الطرس: الصحيفة ... ابن

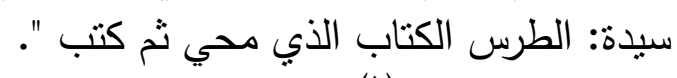
وقال البستاني ('): القرطاس: الأي مثلثة القاف (وكسر القاف أعلى) الصحيفة التي

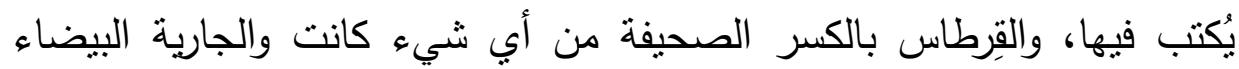

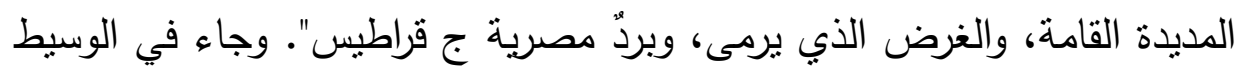

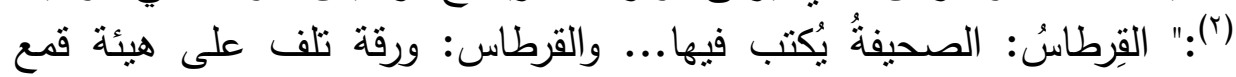

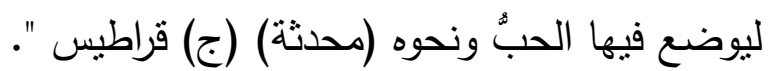

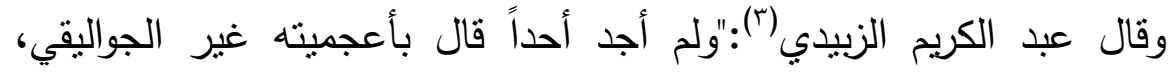

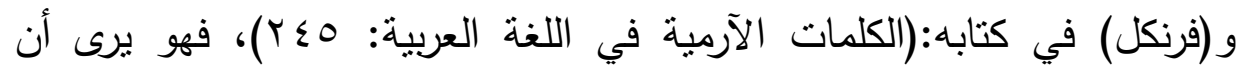

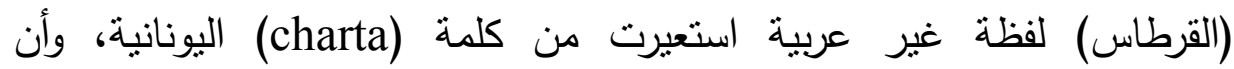

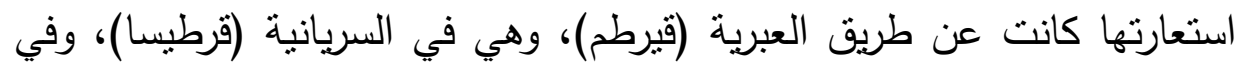
الحبشية (kertas)، كما في الترجمة الإنجيلية، وهي إذن وهي فأخوذة عن الإغرية أغرطيق أوفي القبطية ".

أقول إنّ أئمة التفسير واللغة لم يذكروا أنها أعجمية، والذي أرجحه أنها لفظة

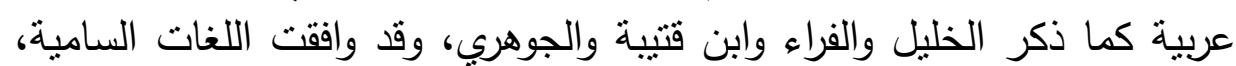
فهي من الألفاظ المشتركة بين اللغات.

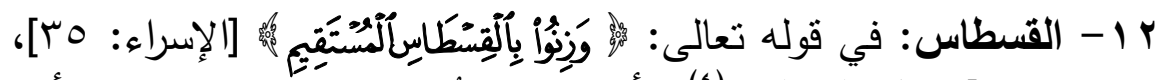

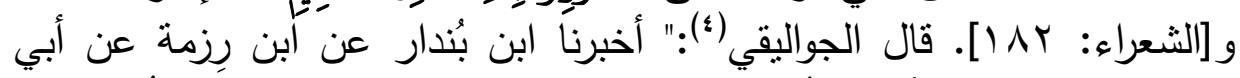

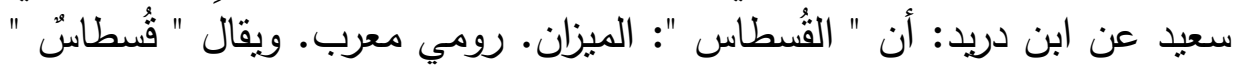

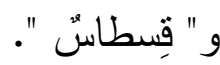

$$
\begin{aligned}
& \text { (البستاني، الوافي، (قرطس) (الوطن) } \\
& \text { (Y) الوسيط: (قرطس) الرسي) }
\end{aligned}
$$

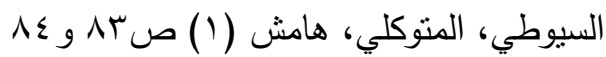

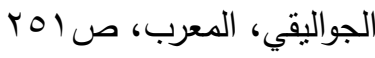




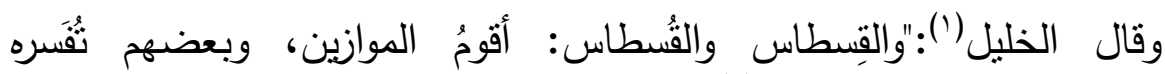

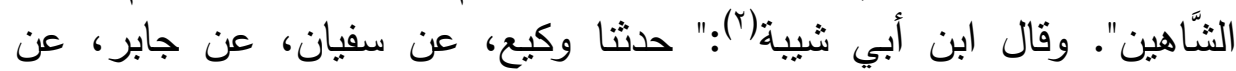

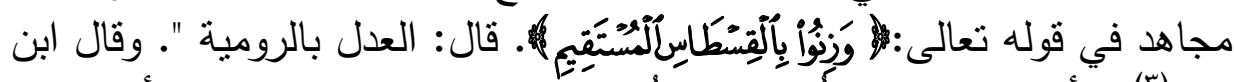

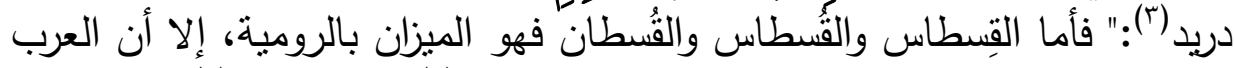

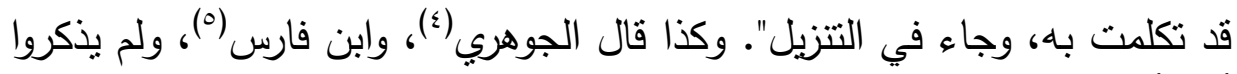
أنَّها أعجمية.

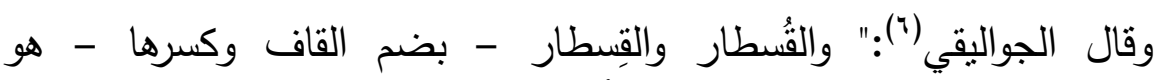

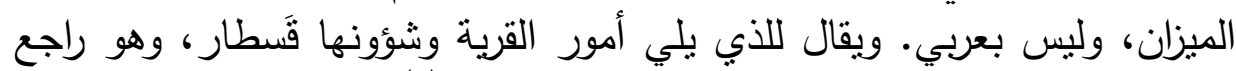

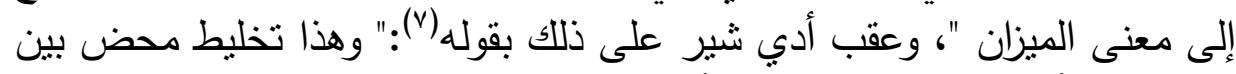

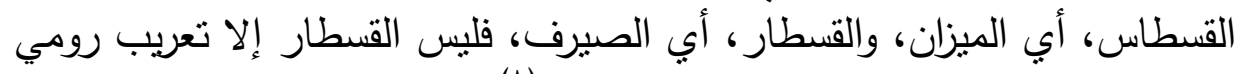
(Quaestor)

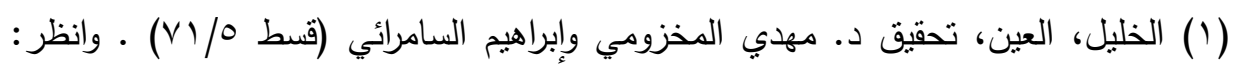

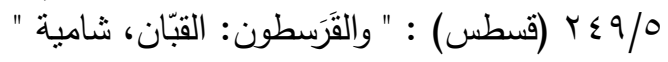

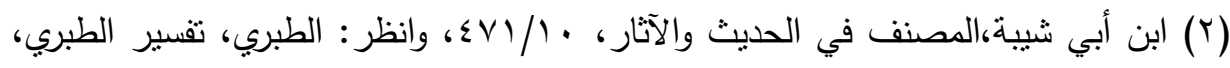

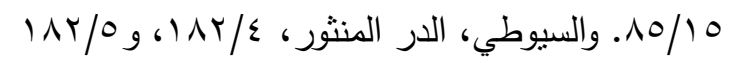

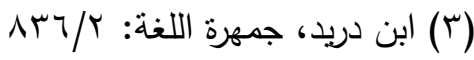

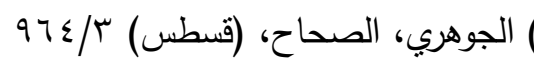

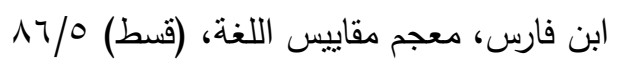

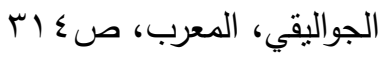

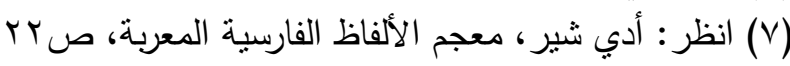

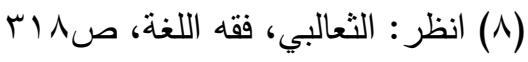




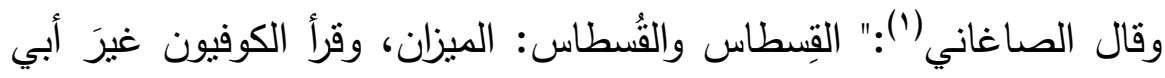

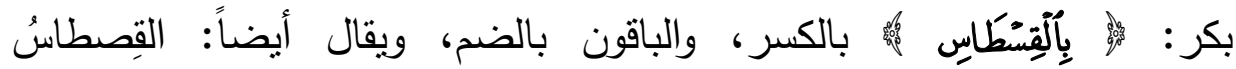

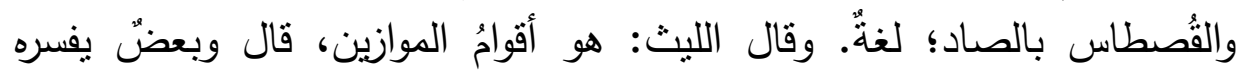

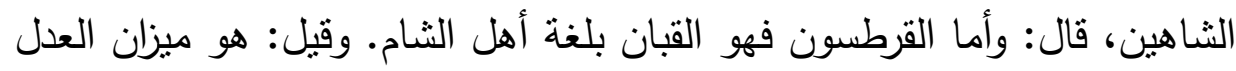

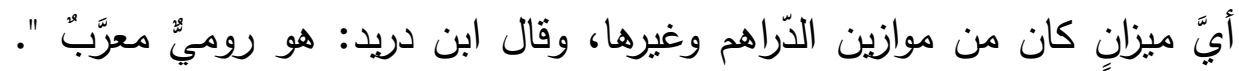

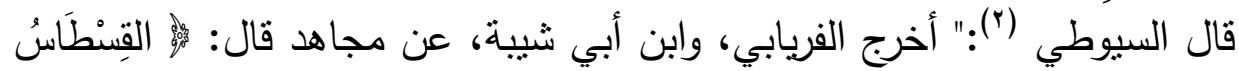

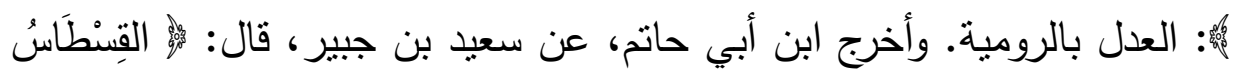

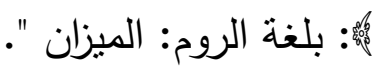

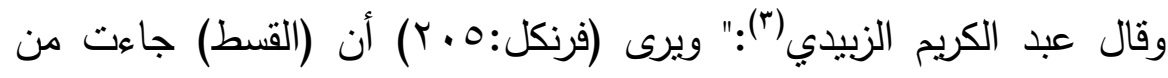

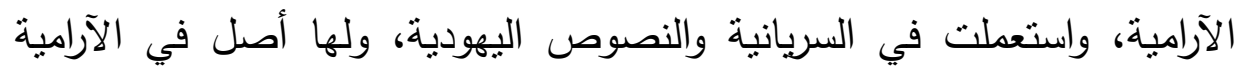

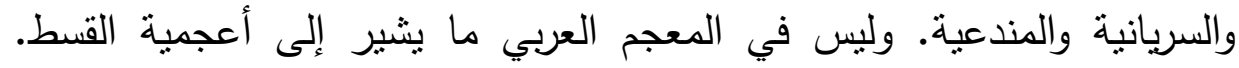

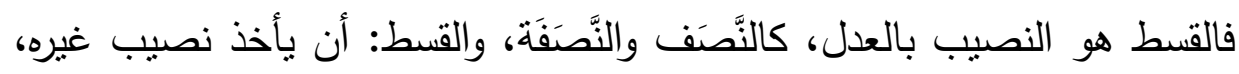

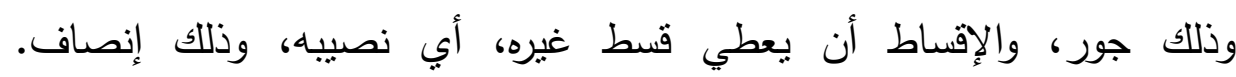

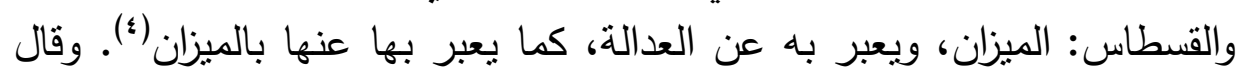

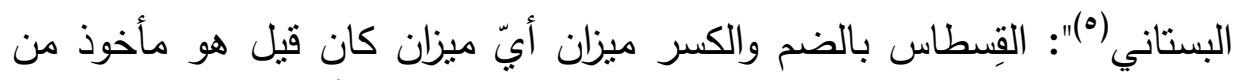

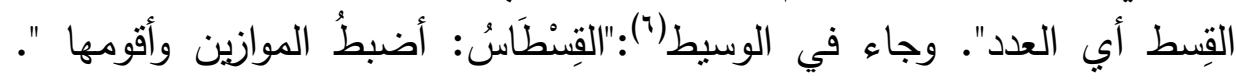

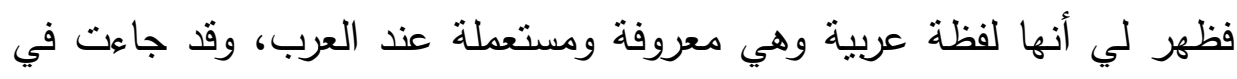

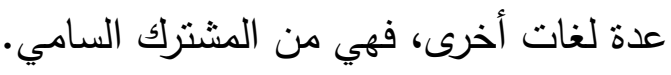

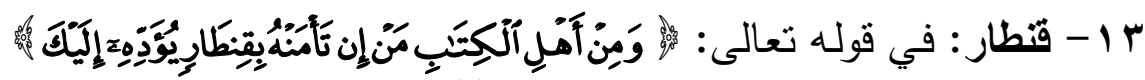

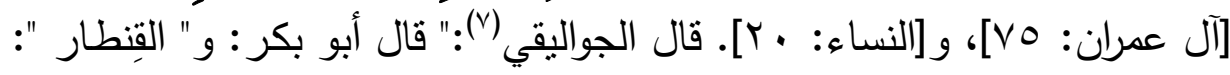

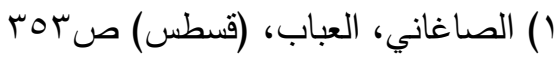

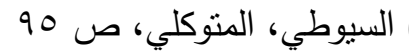

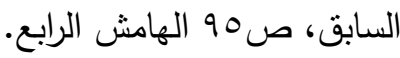

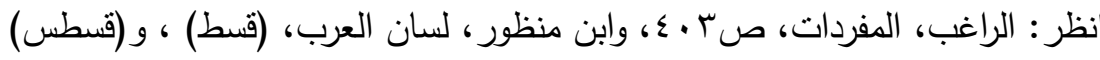

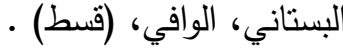

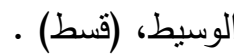


معروف. النون فيه ليست أصلية. واختلفوا فيه. فقال أبو عبيدة: مِلْهُ مَنْلَكِ ثور

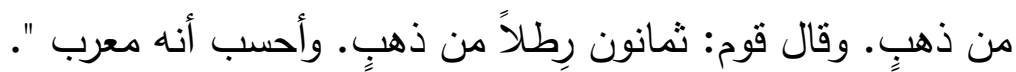

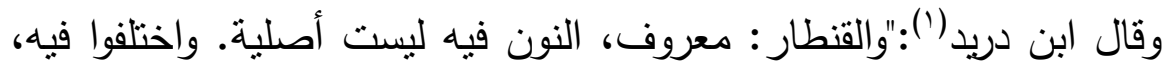

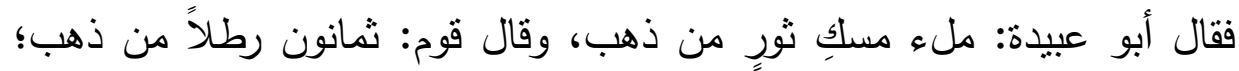

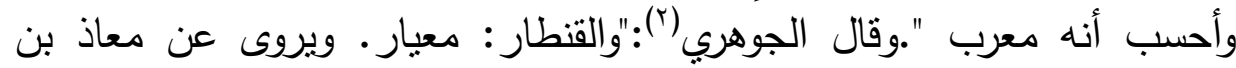

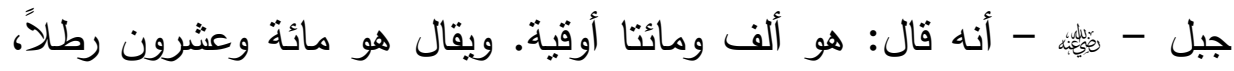
ويقال مله مسك الثور ذهباً. ويقال غير ذلك. واله أعلم. ومنه قولهم قناطيرٌ

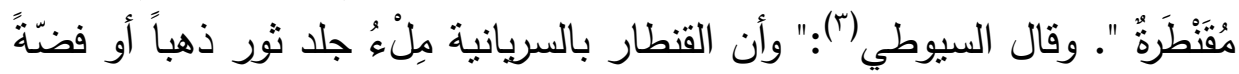
". وقال أيضًا (؛):" وذكر الثعالبي في (فقه اللغة) أن (القنطار) بالرومية: الثا

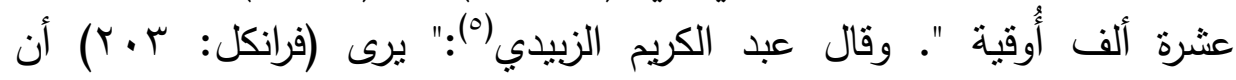

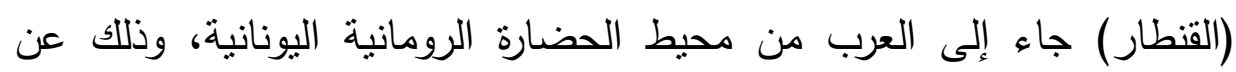

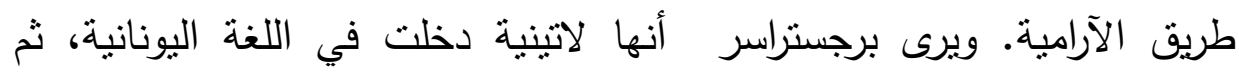

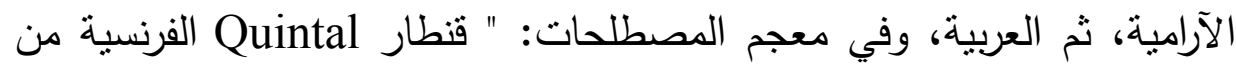
كلمة لاتينية القرون الوسطى. وهذه الكلمة من العربية. والقنطار المتري: مائة

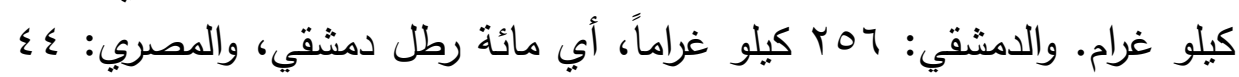

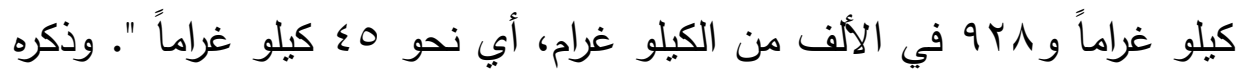

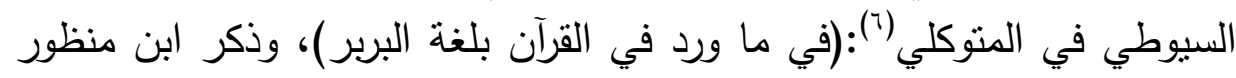

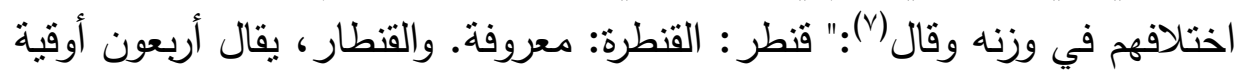

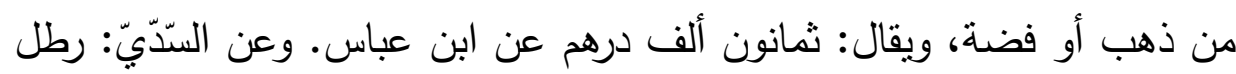
من ذهب أو فضة، ويقال هو بالسريانية منل مِله جلد ثورٍ ذهباً أو فضةً.

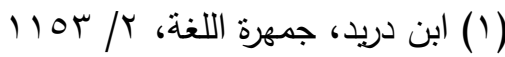

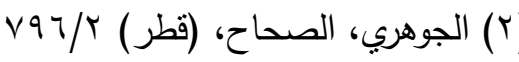

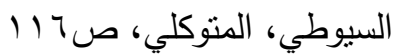

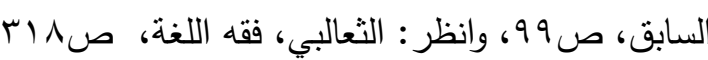

$$
\begin{aligned}
& \text { (1) السيوطي، المتوكلي: ص99، 9 الهامش الثالث. }
\end{aligned}
$$

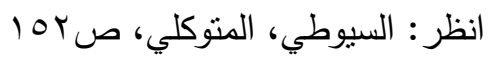

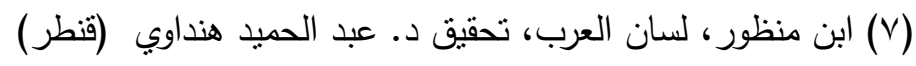




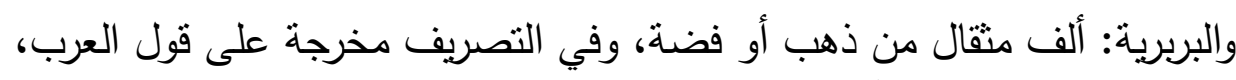

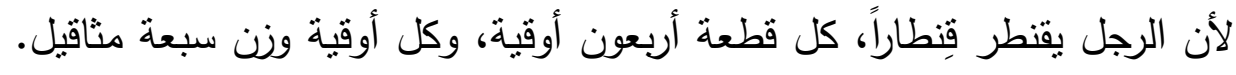

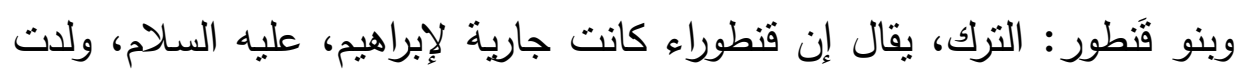

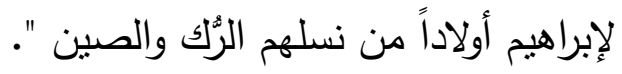

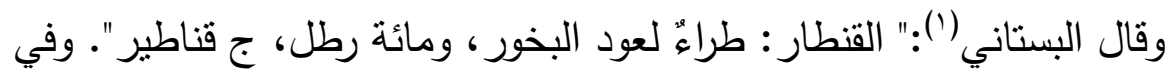

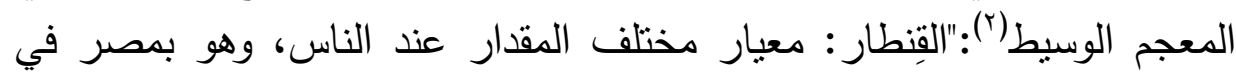

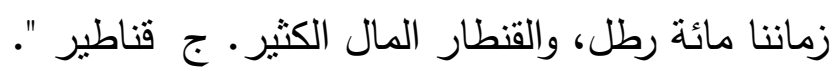

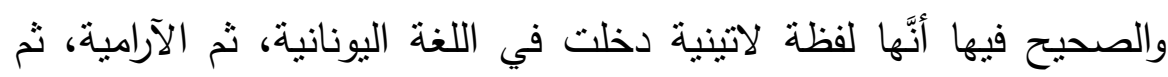

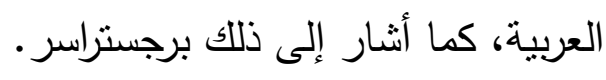

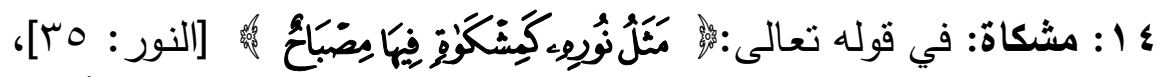

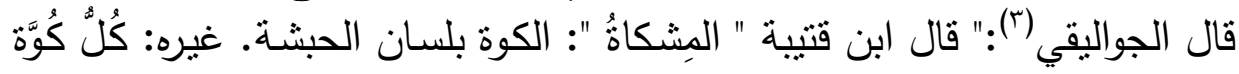

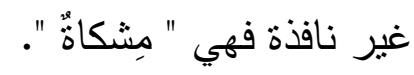

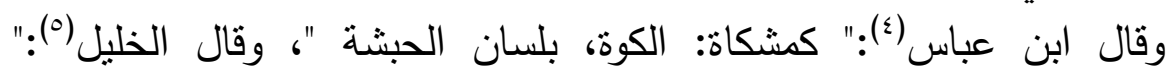

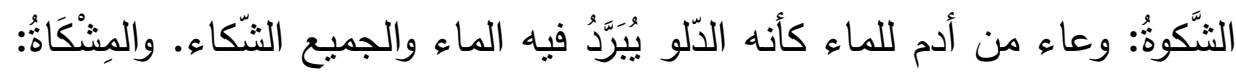

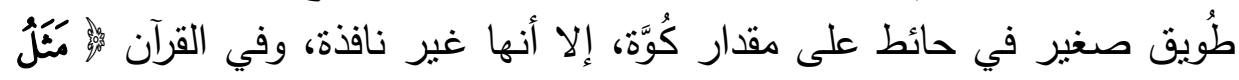

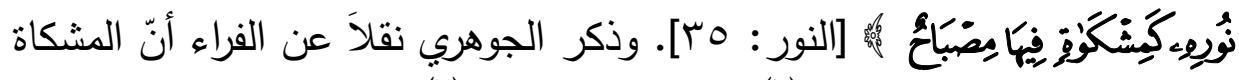

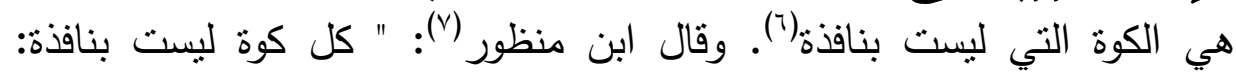

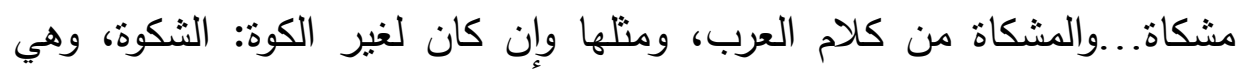

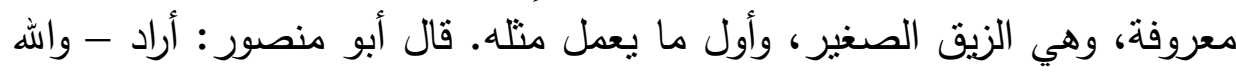

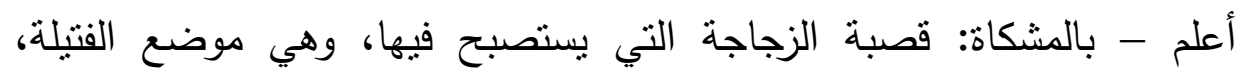

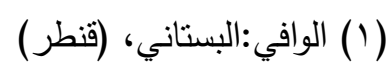

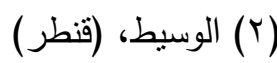

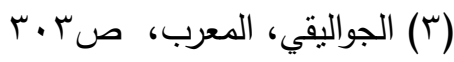

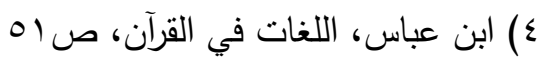

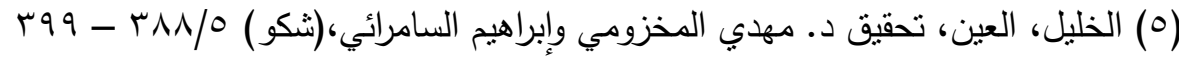

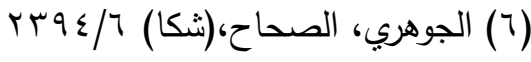

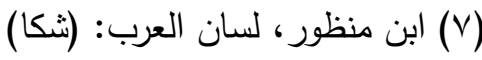




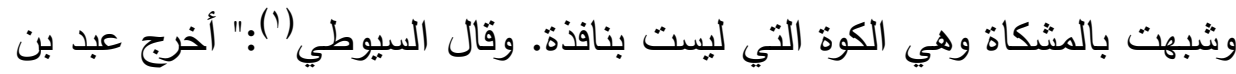

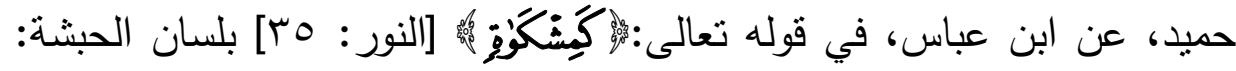

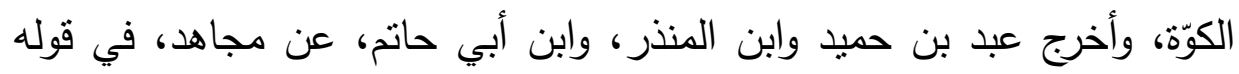

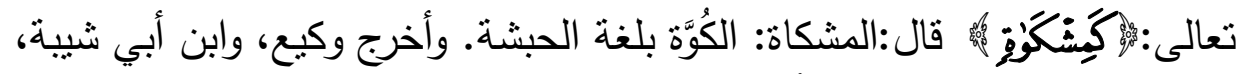

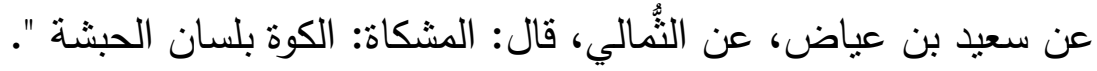

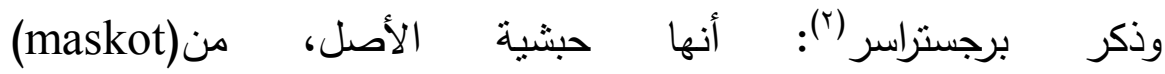

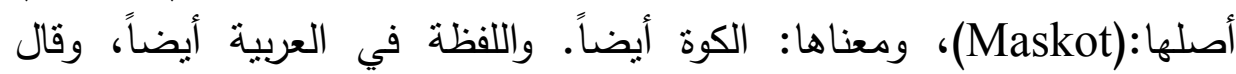

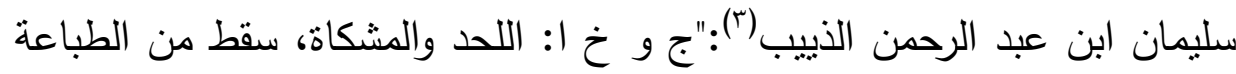

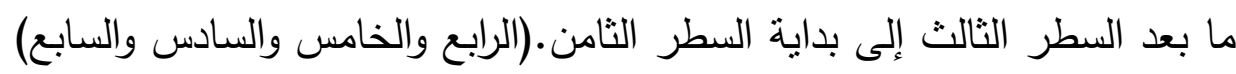

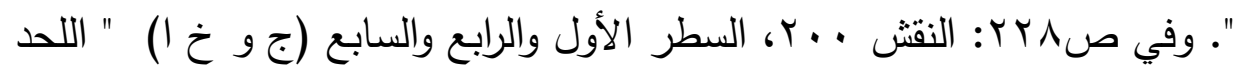

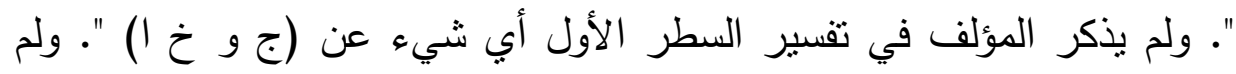

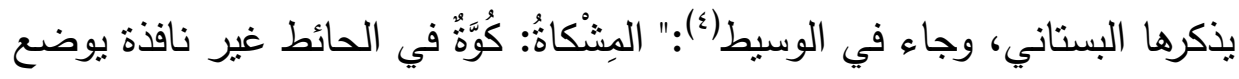

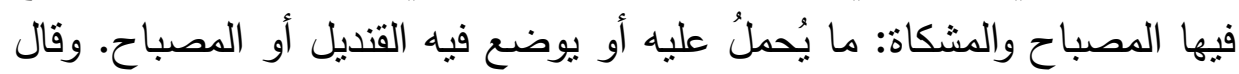

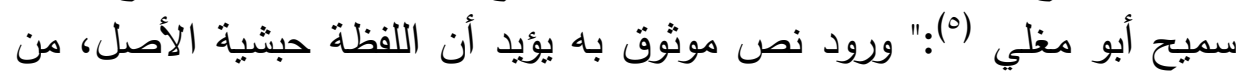

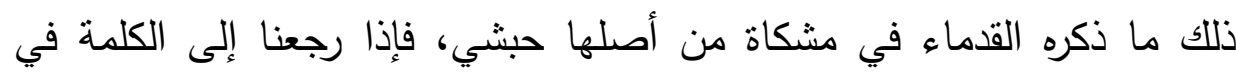
الحبشية نجد أن (Moskot) معناها الكوة وفي القرآن برسم المقطع الثاني بالوال فئاو

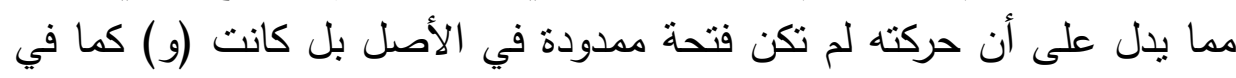

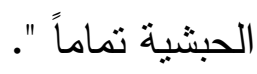

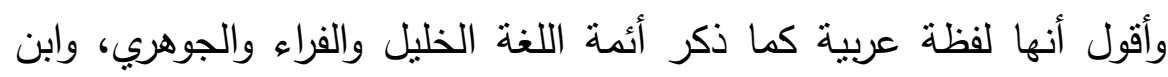
منظور ، وهي لفظة مشتركة بين العربية واللغات الأخرى.

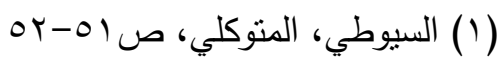

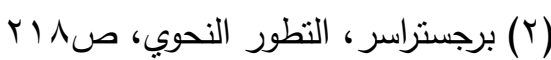

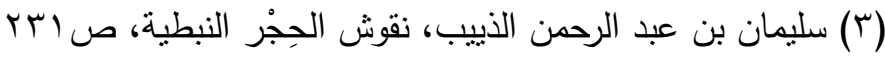

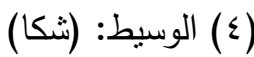

$$
\begin{aligned}
& \text { (0) سميح أبو مغلي، في القرآن من كل لسان، ص } 97 \\
& \text { \&70 }
\end{aligned}
$$




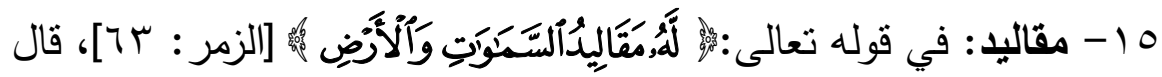

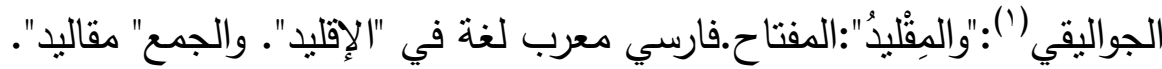

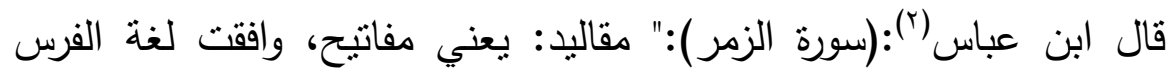

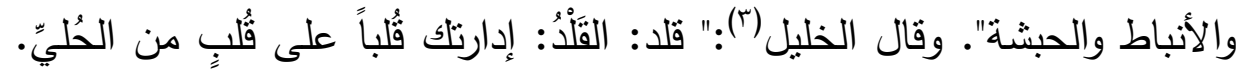

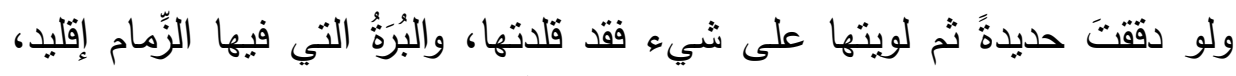

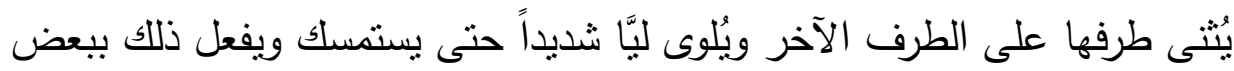

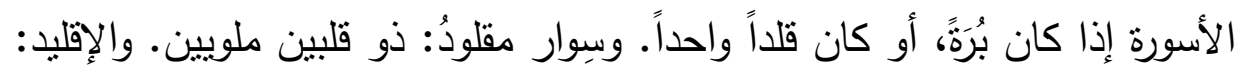

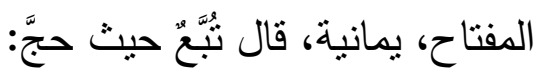
وأقثنا به من الدّهر سبتاً وجعلنا لبابه إقليدا

ويروى: سِتًاً. والمقلاد: الخِزانة، ويجمع مقاليد. وأقلد البحر على خلق كثير

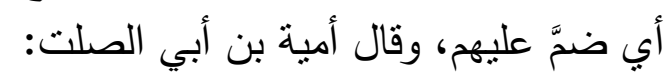

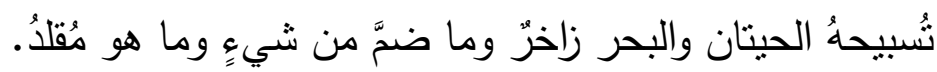
وتقول هي قلادة الإنسان والبدنة والكلب ونحوه ". وقيل إنّها مفاتيح وخزائن

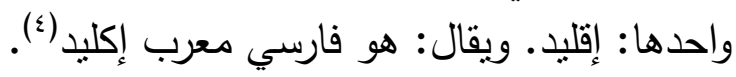

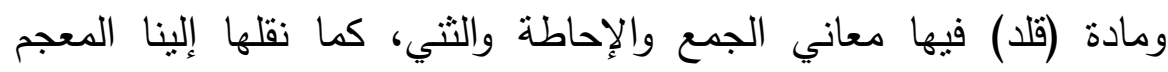

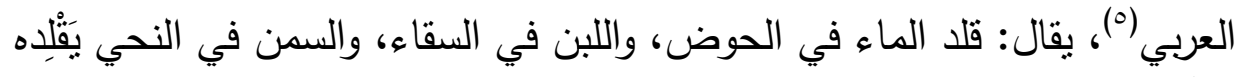

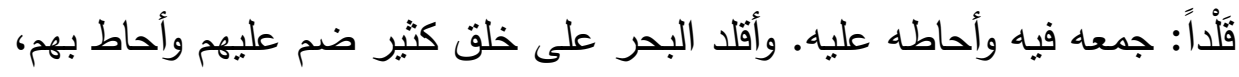

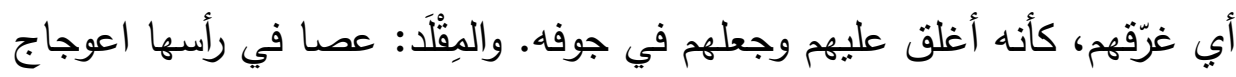

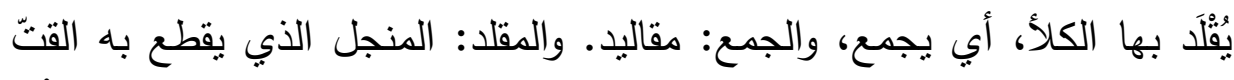

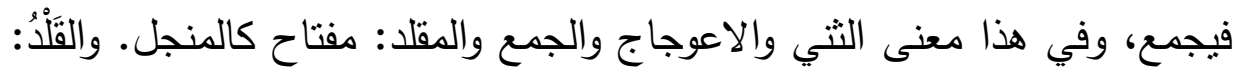

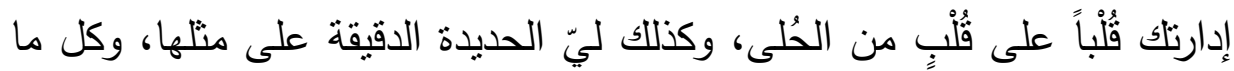

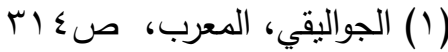

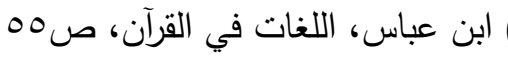

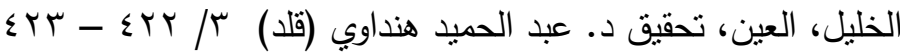

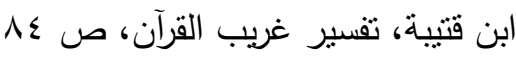

$$
\begin{aligned}
& \text { ابن منظور ، لسان العرب، (قلد فئل }
\end{aligned}
$$


لوى على شيء فقد قلد. والإقليد: الدفتاح. يمانية، والمقاليد الخزائن.والإقلليد: شريط

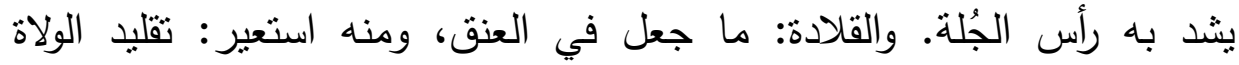

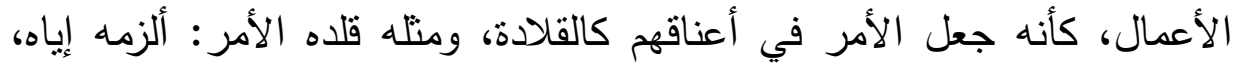

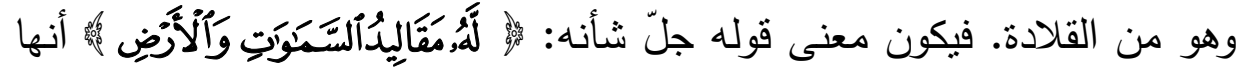

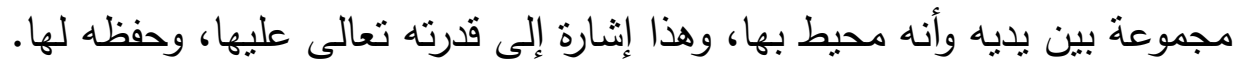

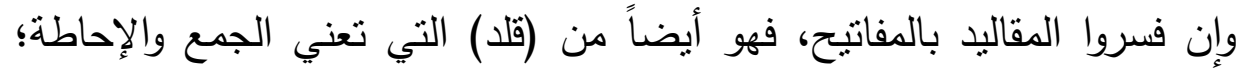

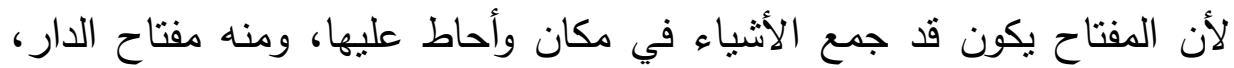

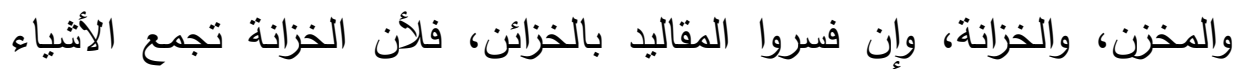
وتحيط بها. وإن قالوا: هو معرب (إنليد) بالفارسية.

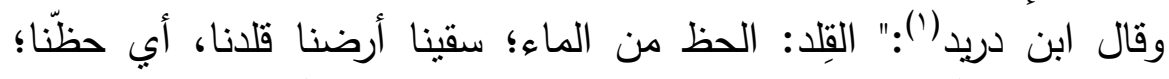

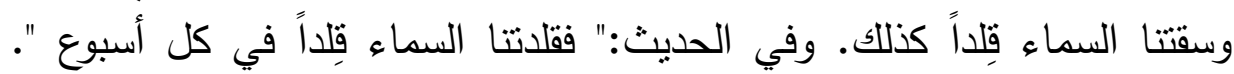

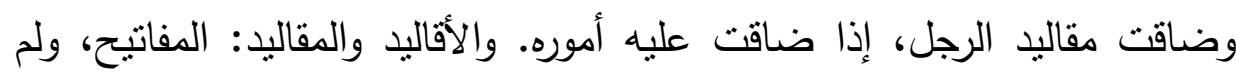

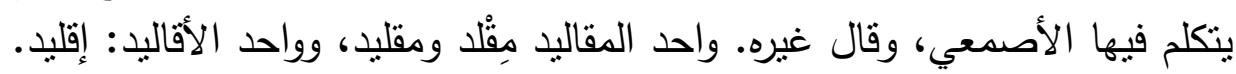

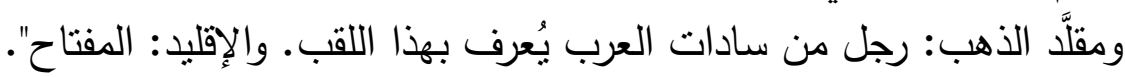

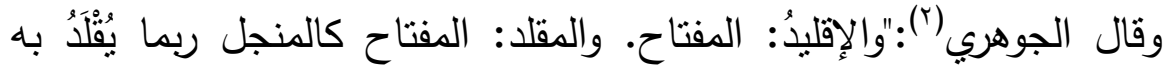

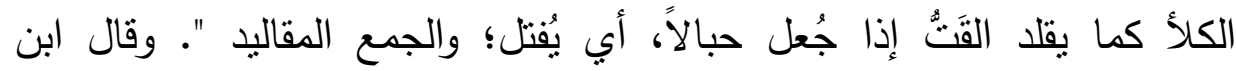

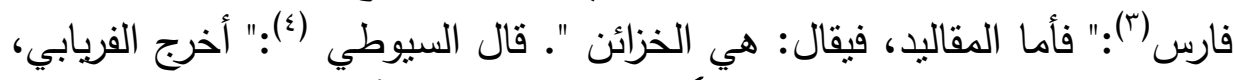

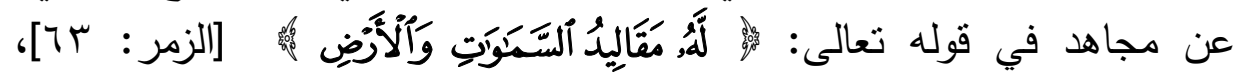
و [الثورى: 1 1]]، قال: مفاتيح، بالفارسية ".

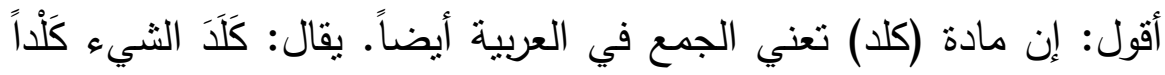

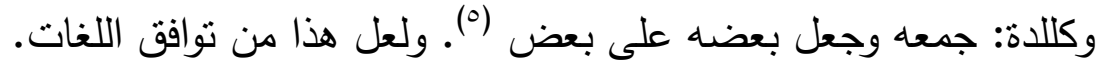

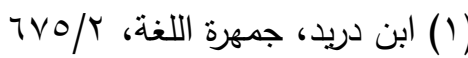

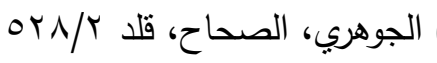

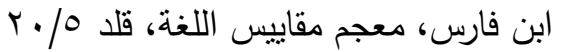

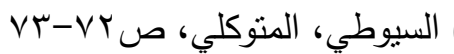

(0) انظر : ابن منظور ، لسان العرب: (قلد) ، والراغب الأصفهاني، المفردات، ص الاع 


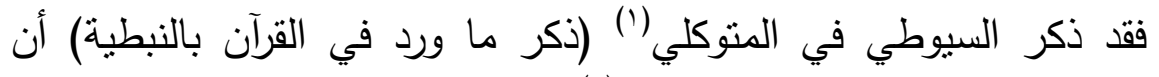

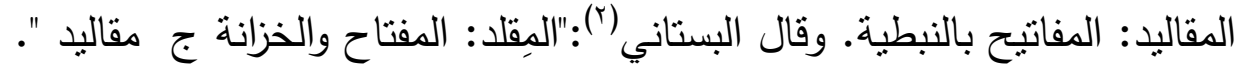

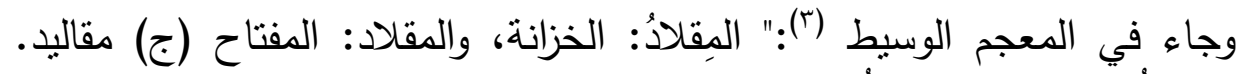

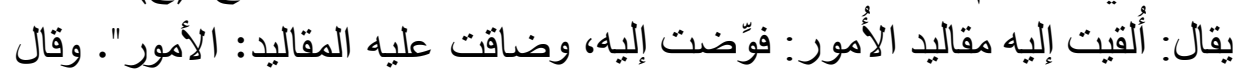

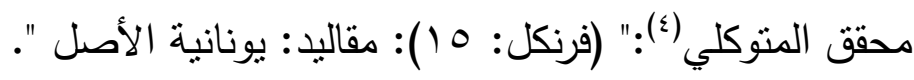

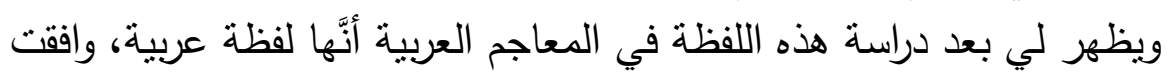

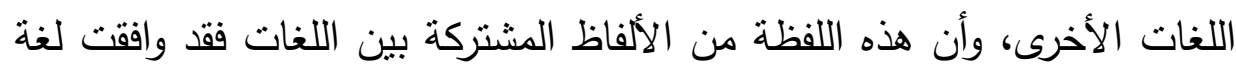
اليونان والفرس والأنباط والحبشة. 


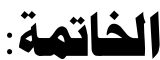

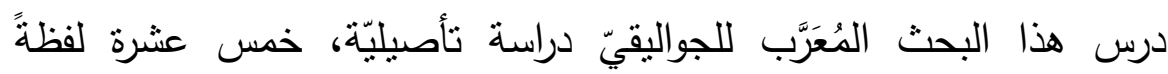

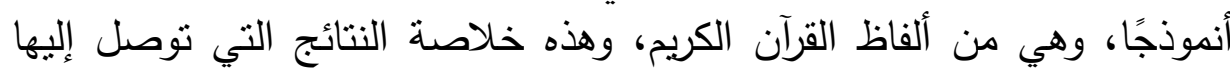

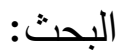

1- أصاب الجواليقيّ في لفظتين من خمس عشرة لفظة، وهما (إستبرق: فارسي معرب، وغساق: تركية).

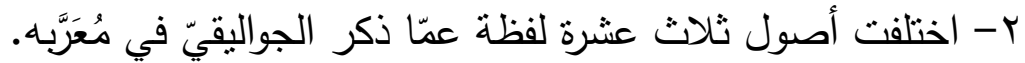

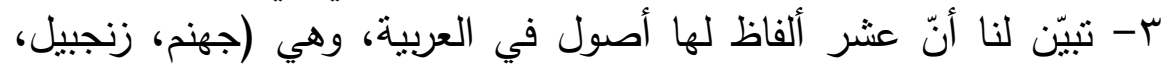

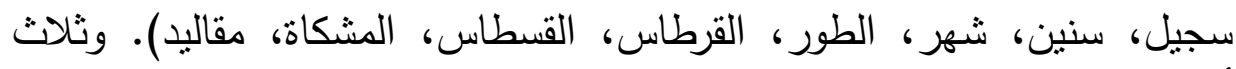

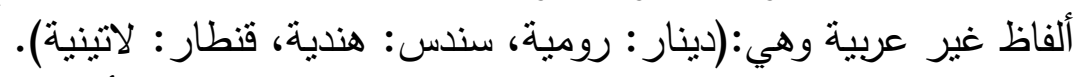
ع - التسرع في نسبة بعض الألفاظ إلى الفارسية، وقد ثبت أنّانها ليست فارسية في هذه الدراسة. 0- ثمة ألفاظ اختلف في أصلها، مثلاً: (قنطار ، الثعالبي رومية، الجواليقيّ:

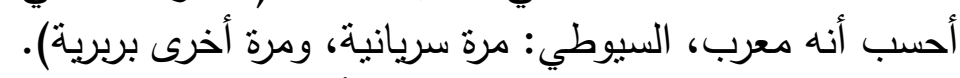

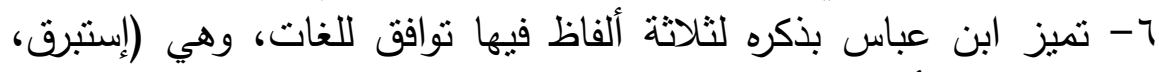
والطور ، مقاليد، وقد أصاب في انثتين وهما الطور، ومقاليد).

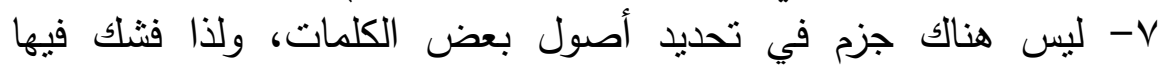

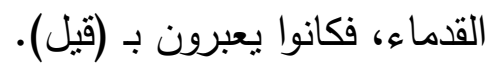
1 - ثمة خلط بين الهندية والفارسية، حتى إنّه لا فكرة لديهم عن اللغة الهندية القديمة (السنسكريتية).

9- ظهر لي عدم إتقان بعض القدماء للغات السامية، وعدم تمكنهم منها.

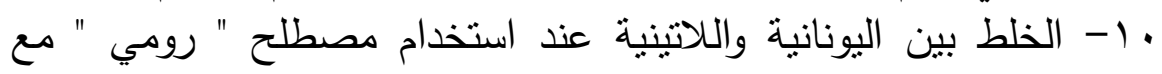
وجود اختلاف بين اللغتين.

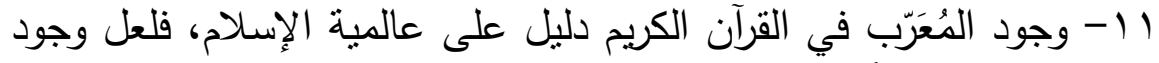

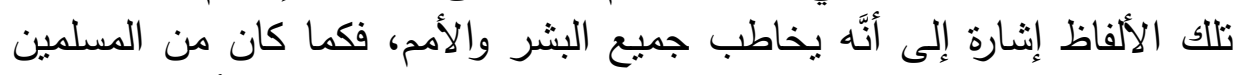

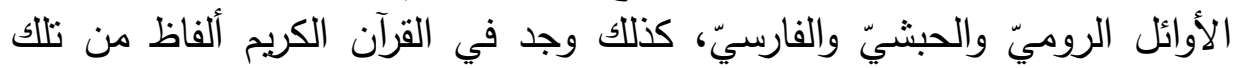

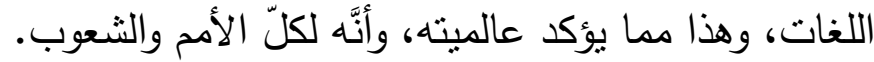

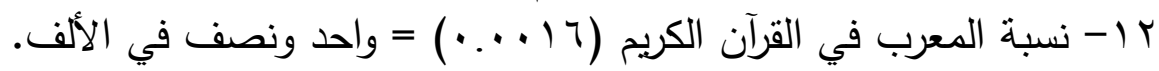
وهذه نسبة قليلة جدًا، ولا تؤثر في عربية القرآن الكريم. 


\section{جدول الألفاظ المُمَرَبة التي درست في البحث}

\begin{tabular}{|c|c|c|c|}
\hline 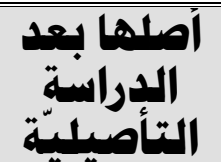 & قول الجواليقى & أول هَن ذكر أنَّها أعبميمية & |لالفظة \\
\hline فارسي معرب & فارس الجواليقيّ & 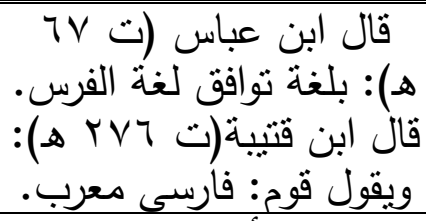 & الإستبرق \\
\hline الألغاتة وافقت & & 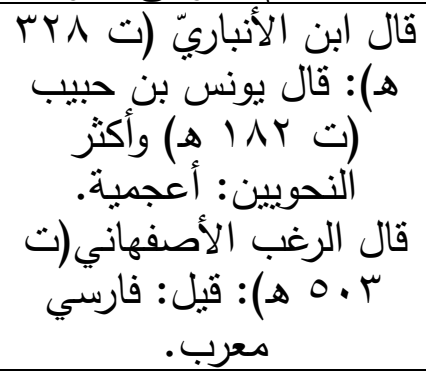 & r- جهنم \\
\hline رومية & فارس الجواليقيّ: & قال الجواليقيّ: فارسي & " - دينار \\
\hline عربية، وافقت اللأخات & - & 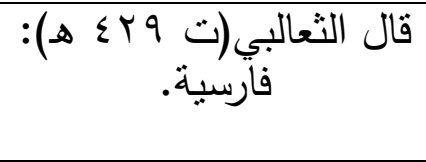 & ع- زنجبيل \\
\hline عربية، وافقت اللخات & - & قال ابن عباس: بالفارسية. & 0- سجيل \\
\hline هندية & قال الجواليقيَ: & 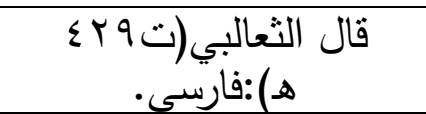 & 7- سندس \\
\hline عربية، وهية & ققال الجواليقِيّ: & 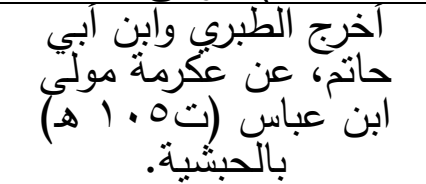 & V - Vنين \\
\hline
\end{tabular}




\begin{tabular}{|c|c|c|c|}
\hline عربية، وافقت اللخات & - & قال الجواليقيّ: قال أهل & 1- شهر \\
\hline عربية، وافقت اللغات & & 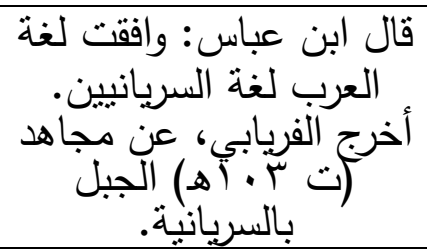 & 9- الطور \\
\hline تركية & & 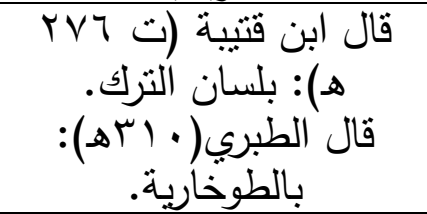 & • 1 - غساق \\
\hline عربية، وافقت اللأخات & 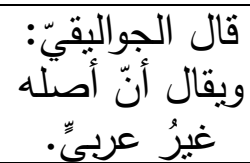 & 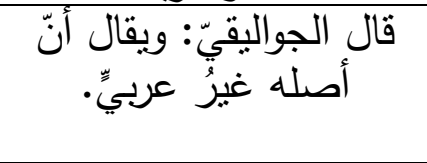 & $\begin{array}{l}11 \\
\text { القرطاس }\end{array}$ \\
\hline مربية، وهية مشتية & قال الجواليقيّ: & 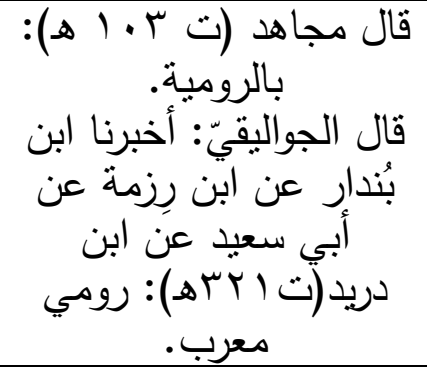 & 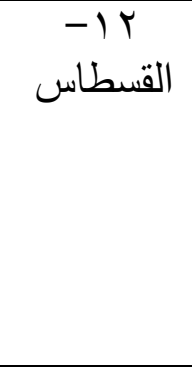 \\
\hline لاتينية & قأل الجواليقيّ: & قال السيوطي البي: بالرومية. & rا - قنطار \\
\hline عربية، وافقت اللخات & & قال ابن عباس: بلسان & 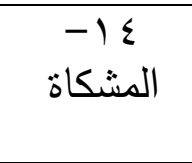 \\
\hline عربية، وافقت اللخات & فارسي معربي البقي: & قال ابن عباس: والفاطن والحبشة لغة. & 10 - مقاليد \\
\hline
\end{tabular}




\section{المصادر والمراجع}

ا - الإتقان في علوم القرآن: جلال الدين عبد الرحمن بن أبي بكر السيوطي، تحقيق: عصام

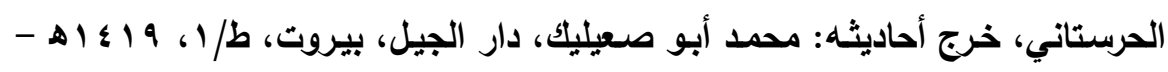

r- التضاد في ضوء اللغات السامية دراسة مقارنة: ريحي كمال، دار النهضة العربية،

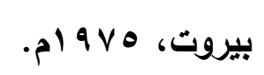

r- التطور النحوي للفة العربية، برجستراسر، نقله إلى العربية، رمضان عبد التواب، مكتبة

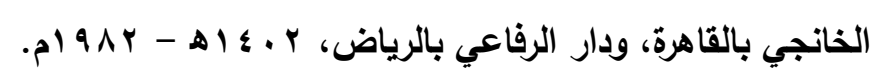

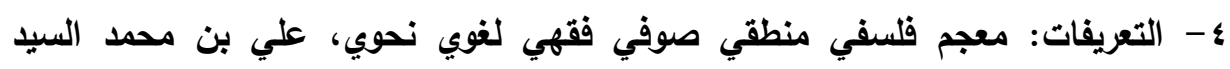

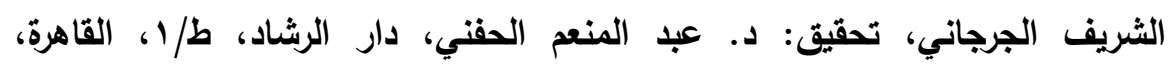

\section{.p 991}

ه- تفسير الطبري - جامع البيان عن تأويل القرآن-، الطبري، ط/ آ، مكتبة ومطبعة

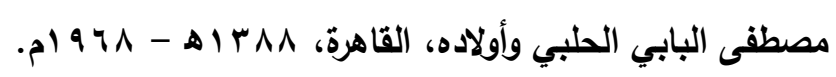

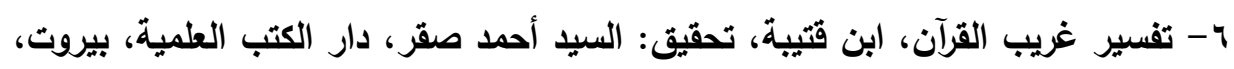

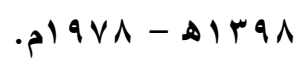

V- تفسير القرطبي: الجامع لأحكام القرآن، أبو عبيد الله محمد بن أحمد القرطبي، دار القلم،

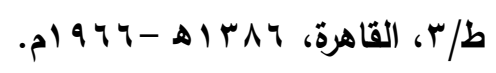

^- تكملة المعاجم العربية: رينهارت دوزي، ترجمة: محد سليم النعيمي، مراجعة: جمال

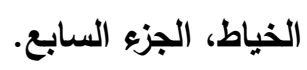

9- جمهرة اللغة، ابن دريد، تحقيق: د. رمزي منير البعلبكي، دار العلم للملايين، ط/ ا،

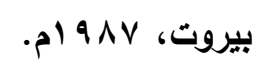

• 1 - الدر المنثور: جلال الدين عبد الرحمن بن أبي بكر السيوطي، تحقيق: نجدت نجيب،

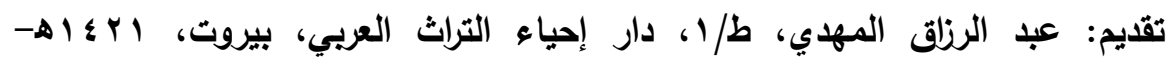

$$
\text { . } 1
$$

11 - روح المعاني في تفسير القرآن العظيم والسبع المثاني: أبو الفضل شهاب الدين السيد

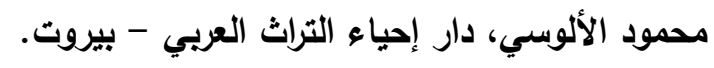

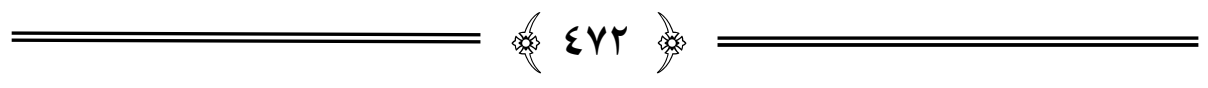


r ا - سفر السعادة وسفير الإفادة، علم الدين السخاوي، رسالة دكتوراة مقدمة من قبل أحمد

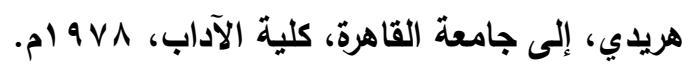

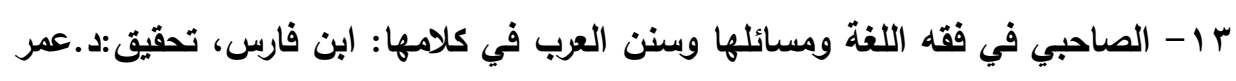

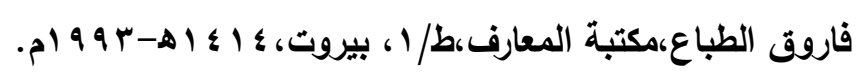

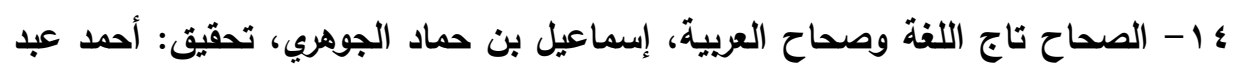

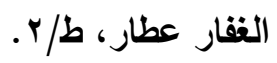

ها - العباب الزاخر واللباب الفـاخر، الحسن بـن محمد الحسن الصـغاني، تحقيق: الثـيخ

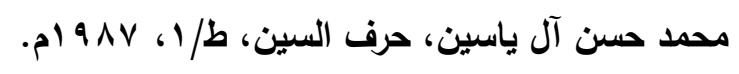
17 - العين: للخليل بن أحمد الفارهيدي. تحقيق:د. مهدي مخزين،

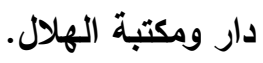

IV - العين: للخليل بن أحمد الفارهيدي. تحقيق: عبد الحميد هنداوي، دار الكتب العلمية،

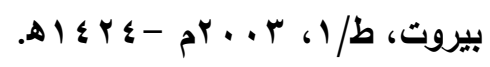

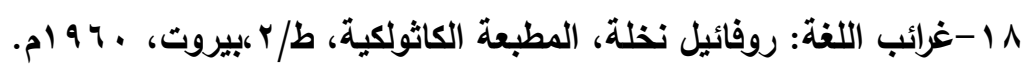

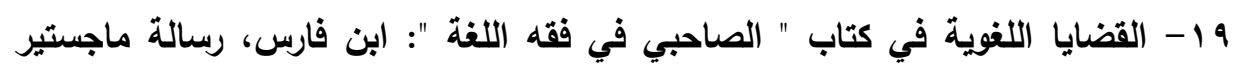

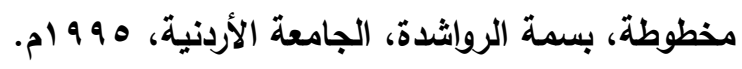
• r فقه اللغة وسر العربية: أبو منصور الثعالبي، دار الكتب العلمية، بيروت.

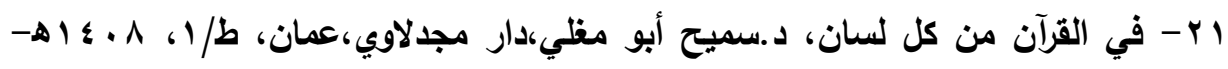
Y Y - الكتابة المسمارية ول الحرف العربي، دراسة تاريخية لغوية للنصوص المسمارية المكتثفة في مدينة تربيصن الآثورية د. عامر سليمان. مركز البحوث الآثارية والحضارية، كلية الآداب - جامعة الموصل.

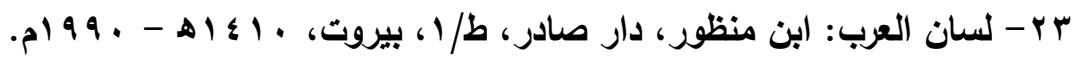

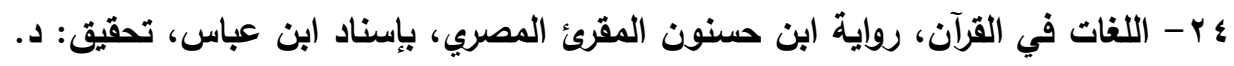

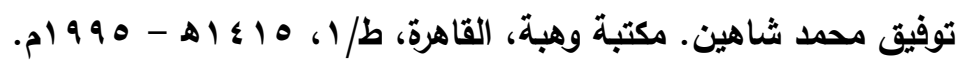

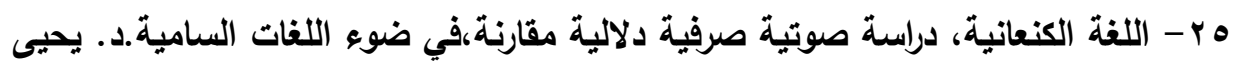

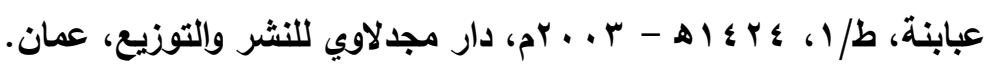

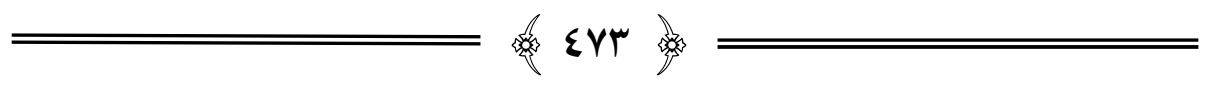


צr- ليس في كلام العرب: ابن خالويه، تحقيق: أحمد عبد الغفور عطار، ط/Y، مكة

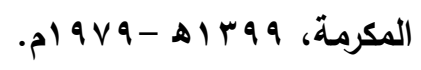

V V - المتوكلي فيما ورد في القرآن باللفات: الحبشية والفارسية والرومية والهندية والسريانية

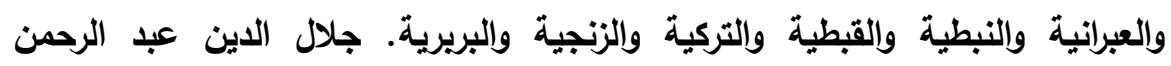

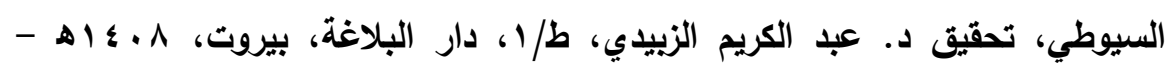
. 9 . 9 1

^r - المدخل إلى اللغة السرياتية: د. أحمد إرحيم هبّو، جامعة حلب، كلية الآداب، مديرية

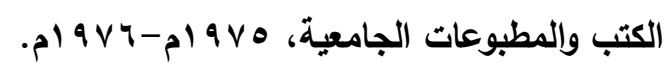

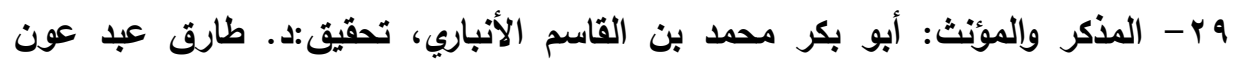

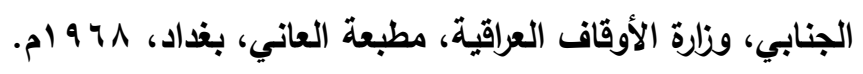

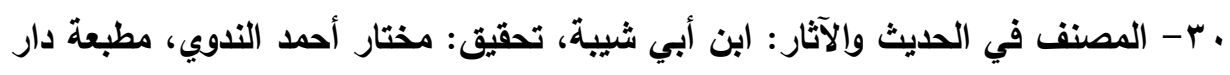

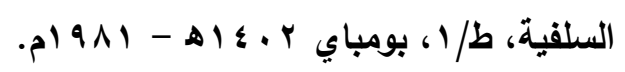

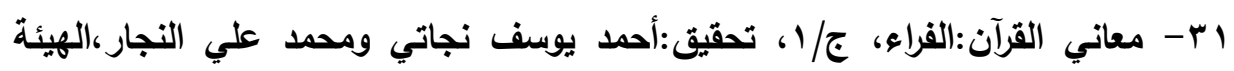

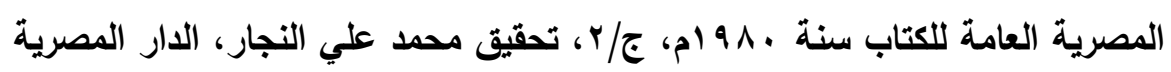

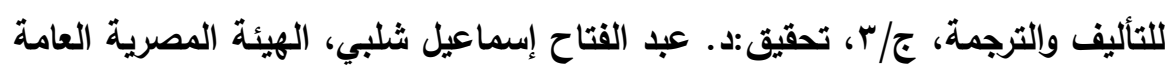

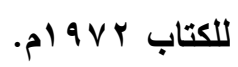

r r - معجم الألفاظ الفارسية المعرية، مكتبة لبنان، بيروت، ـ 91 ام.

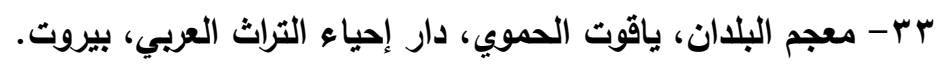

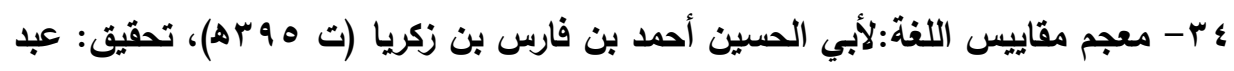

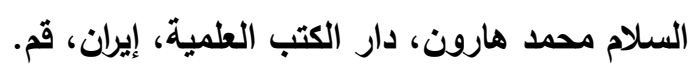

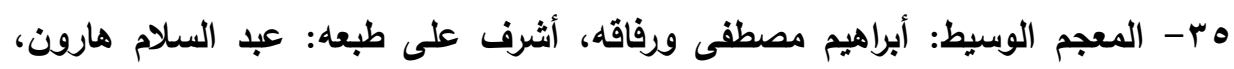
المكتبة العلمية، طهران.

بس- المعرب من الكلام الأعجمي على حروف المعجم: أبو منصور الجواليقي، تحقيق

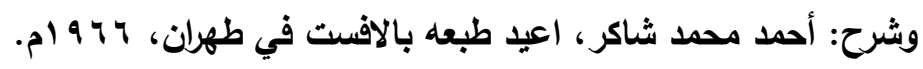

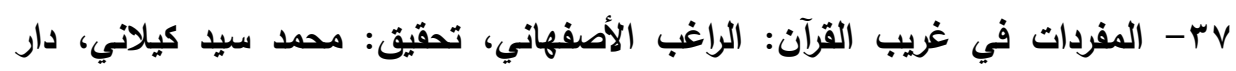

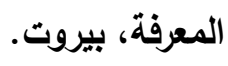

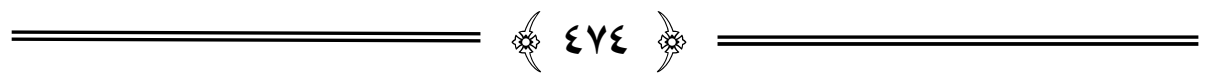


=

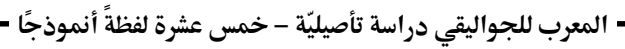

^ץ- النظام اللغوي للهجة الصفاوية، في ضوء الفصحى واللغات السامية.د. يحيى عبابنة،

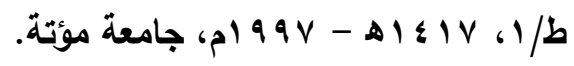

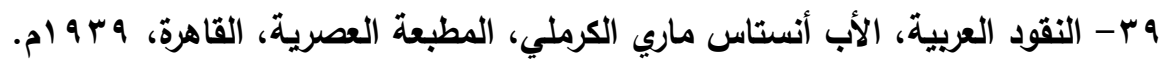

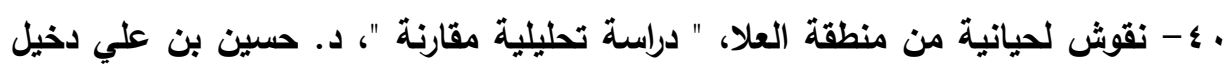

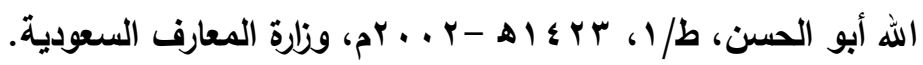

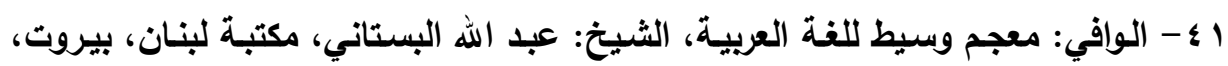
. 191 . 


\section{ב

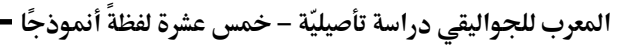

\section{ABSTRACT:}

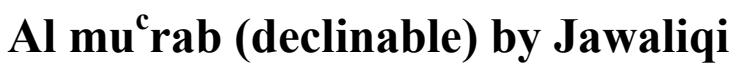

(arootage study on fifteen koranic words)

By

Dr: Sulieman Oudeh Abu Su'aileek

Assistant Professor departmant of Arabic Language and literature. College of Arts. king Saud University,

Riyadh

This research examines the roots of fifteen mucrab words mentioned in the wholly Koran. It, moreover, shows the different views stated by a number of scholars specialized on koranic interpretation, koranic readings, language, and grammar; both ancient and modern ones. It compares these views to what has been mentioned by Jawaliqi.

According to this study Jawaliqi succeeded in clarifying the correct roots of two words only. However, the correct roots of the remaining words contradict what is stated by him. he was mistaken in contributing some of the words concerned to the Persian language.

This research came to the conclusion that most of these words originally belonge to the Arabic language. Atable of the concerned words is made in this research; along with the result of the rootage stady.

Keywords: $\mathrm{Al} \mathrm{mu}^{\mathrm{c}}$ rab (declinable), Jawaliqi, rootage stady, koranic words. 